Daniel Lino Teodoro

\title{
APRENDIZAGEM COOPERATIVA NO ENSINO DE QUÍMICA: INVESTIGANDO UMA ATIVIDADE DIDÁTICA ELABORADA NO FORMATO JIGSAW
}

\author{
Dissertação apresentada ao Instituto \\ de Química de São Carlos, da \\ Universidade de São Paulo para \\ obtenção do título de Mestre em \\ Ciências (Química Analítica).
}

Orientadora: Profa. Dra. Salete Linhares Queiroz

São Carlos 


\section{Dedicatória}

Dedico este trabalho à minha mãe Maria, pelo amor e incentivo, aos meus irmãos Marcio, Elisangela e Gisele, pelo apoio e participação em todas as etapas da minha vida e que com seus filhos ajudaram a dar sentido a minha vida. In memórian de Willian F. Teodoro, eternamente a parte mais pura do meu ser. 


\section{AGRADECIMENTOS}

À minha orientadora Profa. Dra. Salete Linhares Queiroz, por ter me guiado pelos melhores caminhos, por mais que os mesmos não sejam os mais fáceis, me ajudando a superar as dificuldades, se tornando assim a exata tradução da palavra orientar. Ao Instituto de Química de São Carlos, da Universidade de São Paulo, pela estrutura oferecida aos alunos de mestrado.

À minha mãe Maria E. Barbosa pela vida, amor e valores.

À minha Irmã Gisele L. Teodoro pela coragem com que me fez ver a vida.

À minha irmã Elisangela L. Teodoro pelo exemplo de dedicação e competência e ao meu cunhado Alexandre G. dos Santos por estar sempre disposto a ouvir e participar da minha história.

Ao meu irmão Antonio Marcio Barbosa que mesmo distante me faz ter vontade de continuar lutando.

À minha tia Maria Irene B. Gomes pelo amor e valores.

À minha sobrinha, mais que querida, Larissa L. Negreli, meu reflexo perfeito.

Aos meus irmãos orientais Leonardo E. O. Iwaki e Letícia E. Moriyama, amigos em todas as horas.

À Karla C. Saqueto, a quem devo parte dessa dissertação, que esteve ao meu lado ajudando em sua construção.

Ao Josué $\mathrm{F}$ Teodoro meu amigo e irmão de hoje e sempre.

Aos meus grandes amigos Adilson, João Claudio, Henrique, Jarlem, Vitor e a todos meus familiares por acreditarem na minha capacidade.

Aos meus colegas do Grupo de Pesquisa em Ensino de Química.

Ao CNPq, pela bolsa concedida. 


\section{RESUMO}

Desde o início da década de setenta, a discussão a respeito das formas de organização e da efetividade das atividades didáticas pautadas nos princípios da aprendizagem cooperativa vem se destacando em vários países europeus e na América do Norte, entretanto no Brasil são ainda escassas as pesquisas dedicadas à temática, especialmente no ensino de Química.

A aprendizagem cooperativa apresenta como característica chave a sua natureza social, pois os estudantes interagem e compartilham suas ideias melhorando sua compreensão individual e mútua. Nesse contexto, aplicamos uma atividade didática de caráter cooperativo (formato jigsaw), em disciplina de comunicação científica oferecida a graduandos em Química, na qual investigamos a dinâmica das interações estabelecidas entre os alunos, dentro dos seus respectivos grupos, a partir da análise das seguintes dimensões: funções da fala, processamento cognitivo e processamento social. Para tanto, nos baseamos no Modelo Analítico proposto por Kumpulainen e Mutanen. De forma complementar, analisamos as percepções dos alunos com relação à atividade.

As interações foram realizadas apresentando como predominante 0 processamento social do tipo colaborativo e os alunos fizeram uso das funções de fala de forma igualitária. Estas foram também marcadas pela presença do processamento cognitivo exploratório, que somado ao uso de funções de fala do tipo críticas, indicam que a atividade foi rica em possibilidades cognitivas.

Desta forma, as três dimensões analisadas sugerem que a atividade se mostrou efetiva, no que diz respeito ao desenvolvimento de condições para aprendizagem cooperativa com foco no desenvolvimento de habilidades sociais, sem, no entanto, 
comprometer o aprendizado de conteúdos da disciplina. As percepções dos alunos com relação à atividade indicaram a sua boa receptividade. Ademais, os alunos destacaram a importância da sua realização para uma melhor resolução dos problemas propostos. Assim, acreditamos que atividades cooperativas, especialmente aquelas no formato jigsaw, podem ser realizadas com sucesso no ensino superior de Química, sendo relevantes para a formação dos graduandos. 


\begin{abstract}
Since the beginning of the 70 s, the discussion about ways of organization and effectiveness of learning activities based on cooperative learning has been growing in many European countries and in North America; however in Brazil, there is a dearth of studies on this topic, especially in chemistry teaching.

One of the key characteristics of cooperative learning is social nature since students interact and share their ideas increasing their individual and mutual comprehension. In this context, we applied a didactic activity based on cooperative learning principles (jigsaw format) in a scientific communication course offered to undergraduate chemistry students. Based on the analytic framework proposed by Kumpulainen and Mutanen, we investigated the dynamic of interactions among the students within the groups focusing on the following dimensions: cognitive processing, social processing, and verbal interactions. We also analyzed the students' perceptions related to this activity.
\end{abstract}

The major cognitive processing observed was interpretative, whereas the social processing was collaborative, which indicate that the activity was rich of cognitive possibilities. Therefore, the dimensions analyzed suggest that the activity was effective in cooperative learning perspective without compromising the learning of the course contents.

The students' perceptions indicated the success of the activity. Moreover, the students highlighted its importance to solve the problems proposed. In sum, we believe that cooperative activities, especially in the jigsaw format, can be effectively used in undergraduate chemistry teaching. 


\section{LISTA DE FIGURAS}

Figura 1.1- Quantidade de trabalhos localizados nas revistas internacionais .26

Figura 1.2 - Distribuição dos trabalhos de acordo com os níveis de escolaridade...... 27

Figura 1.3 - Classificação dos trabalhos de acordo com a área investigada 29

Figura 1.4 - Quantidade de trabalhos publicados nas revistas e nos anais dos ENPECs

Figura 3.1- Esquema de formação de pequenos grupos de discussão pelo método jigsaw adaptado de Barbosa e Jófili (2004). Existe apenas um grupo de origem, que é formado por alunos A, B, C e D (grupo de base). Existem quatro subgrupos, que são formados por alunos A, B, C ou D (grupos de especialistas). As setas indicam a movimentação dos alunos nos grupos: todos são provenientes do grupo de origem e a ele retornam, na etapa final da atividade .50

Figura 4.1- Apresentação dos grupos de base, cada grupo composto por cinco alunos, cada um com um tipo de documento 65

Figura 4.2 - Constituição do grupo de especialistas em artigos de divulgação científica. .66

Figura 5.1- Freqüência de uso das funções de fala por alunos na primeira (a) e segunda atividade dos grupos de base (c) e na atividade dos grupos de especialistas (b).

Figura 5.2 - Porcentagem de uso dos processamentos cognitivos durante a resolução da primeira (a) e segunda (b) atividade dos grupos de base. 82 Figura 5.3 - Porcentagem de uso dos processamentos cognitivos durante a resolução da atividade dos grupos de especialistas. 85

Figura 5.4 - Porcentagem de uso dos processamentos sociais durante a resolução da primeira (a) e segunda (b) atividade dos grupos de base. 
Figura 5.5 - Porcentagem de uso dos processamentos social durante a resolução da atividade dos grupos de especialistas. 89

Figura 5.6 - Questionário de avaliação da atividade proposta, na qual CF= Concordo Fortemente, $\mathrm{C}=$ Concordo $\mathrm{I}=$ Indeciso, $\mathrm{D}=$ Discordo e $\mathrm{DF}=$ Discordo Fortemente........92 


\section{LISTA DE TABELAS}

Tabela 1.1 - Revistas internacionais analisadas, quantidade de trabalhos localizados em cada uma delas e os respectivos períodos em que o levantamento foi realizado ..24 Tabela 1.2 - Artigos sobre o tema aprendizagem cooperativa publicados em revistas internacionais. 25

Tabela 1.3 - Classificação dos trabalhos de acordo com o foco temático 31

Tabela 1.4 - Artigos sobre o tema aprendizagem cooperativa publicados no JCE .......35

Tabela 1.5 - Classificação dos trabalhos de acordo com o foco temático 37

Tabela 1.6 - Revistas nacionais analisadas, quantidade de trabalhos localizados em cada uma delas e os respectivos períodos em que o levantamento foi realizado 40 Tabela 1.7 - Artigos sobre o tema aprendizagem cooperativa publicados em revistas nacionais

Tabela 1.8 - Trabalhos completos apresentados nos ENPECs sobre o tema aprendizagem cooperativa

Tabela 1.9 - Classificação dos trabalhos de acordo com a instituição de origem 43 Tabela 1.10 - Classificação dos trabalhos de acordo com a área de enfoque e nível de escolaridade

Tabela 1.11 - Classificação dos trabalhos de acordo com o foco temático 45 


\section{LISTA DE QUADROS}

Quadro 3.1 - Categorização e descrição das funções de falas (adaptação do trabalho

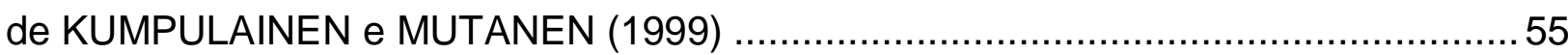

Quadro 3.2 - Categorização e descrição dos processamentos cognitivos.....................57

Quadro 5.1 - Trechos do mapa analítico das interações ocorridas no Grupo 1 .............69 Quadro 5.2-Trechos do mapa analítico das interações ocorridas no Grupo 1, exemplificando as funções de falas pertencente ao primeiro bloco ............................. 73 Quadro 5.3 - Trechos do mapa analítico das interações ocorridas no Grupo 2, exemplificando as funções de falas pertencente ao segundo bloco ........................... 73 Quadro 5.4 - Trechos do mapa analítico das interações ocorridas no Grupo 1, exemplificando as funções de falas pertencente ao terceiro bloco .74

Quadro 5.5 - Distribuição das funções de fala para cada grupo de base participante da primeira e segunda atividade .75

Quadro 5.6 - Distribuição das funções de fala para cada grupo de especialistas 78

Quadro 5.7 - Trechos do mapa analítico das interações ocorridas no Grupo 3 da primeira atividade dos grupos de base, exemplificando os três tipos considerados de processamento cognitivos 


\section{LISTA DE ABREVIATURAS E SIGLAS}

TGT - Teams-Games-Tournament

STAD - Student Teams Achievement Division

ENPEC - Encontro Nacional de Pesquisa em Educação em Ciências

JCE - Journal of Chemical Education

CAPES - Coordenação de Aperfeiçoamento de Pessoal de Nível Superior

Inf - Função de fala - Informação

Ava - Função de fala - Avaliação

Int - Função de fala - Interrogação

Res - Função de fala - Resposta

Res-C - Função de fala - Resposta crítica

C-Res - Função de fala - Complemento de resposta

Org-A - Função de fala - Organização de ação

Org-I - Função de fala - Organização de ideia

Jul - Função de fala - Julgamento

Cit-C - Função de fala - Citação crítica

LVA - Função de fala - Leitura em voz alta

Exp - Função de fala - Experiencial

Afe- Função de fala - Afetiva

Inc- Função de fala - Inclassificável

PCR - Processamento cognitivo - Procedural

PCO - Processamento cognitivo - Off-task

PCE - Processamento cognitivo - Exploratório ou Interpretativo

CF - Concordo Fortemente

C - Concordo 
I - Indeciso

D - Discordo

DF - Discordo Fortemente

IQSC/USP - Instituto de Química de São Carlos da Universidade de São Paulo 


\section{SUMÁRIO}

RESUMO

ABSTRACT

LISTA DE FIGURAS

LISTA DE TABELAS

LISTA DE QUADROS

LISTA DE ABREVIATURAS E SIGLAS

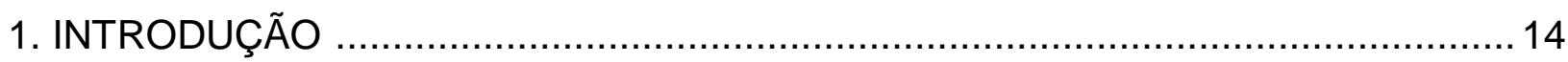

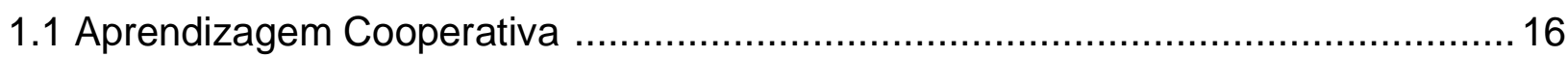

1.2 Aprendizagem Cooperativa no Ensino de Ciências: Panorama das Pesquisas

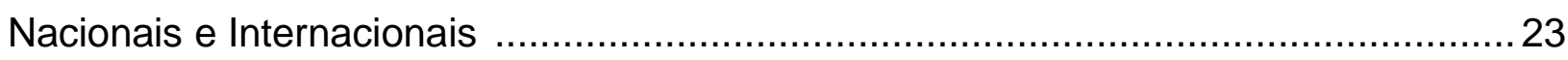

1.2.1 Aprendizagem Cooperativa: Âmbito Internacional ......................................... 24

1.2.2 Aprendizagem Cooperativa: Âmbito Nacional ................................................ 40

2 OBJETIVOS

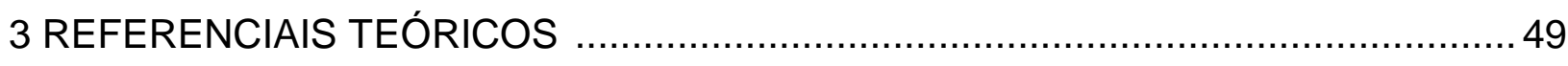

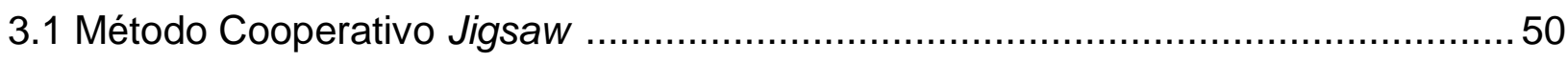

3.2 Modelo Analítico de Kumpulainen e Mutanen ………..........................................53

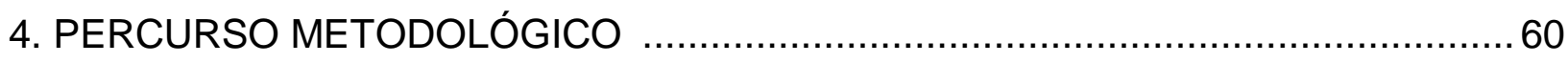

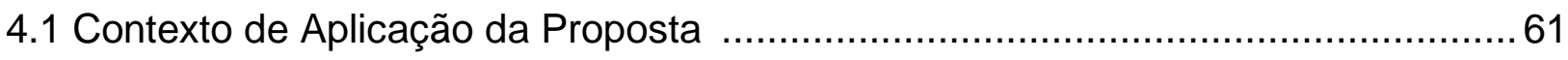

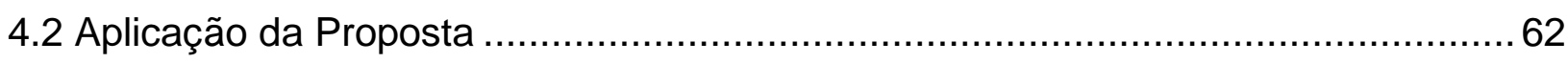

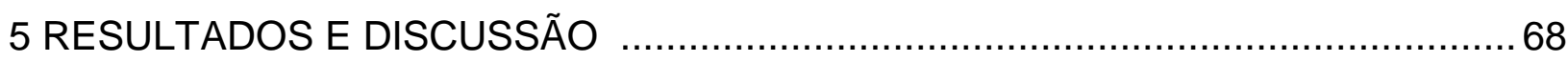

5.1 Primeira Dimensão: Funções de Fala ……………........................................ 70

5.1.1 Distribuição das Funções de Fala por Aluno nas Atividades Realizadas..............70 
5.1.2 Distribuição das Funções de Fala nos Grupos de Base: Primeira e Segunda Atividade .72

5.1.3 Distribuição das Funções de Fala nos Grupos de Especialistas ...................... 78

5.2 Segunda Dimensão: Processamento Cognitivo .......................................... 80

5.2.1 Processamento Cognitivo nos Grupos de Base: Primeira e Segunda Atividade . 80

5.2.2 Processamento Cognitivo nos Grupos de Especialistas................................ 84

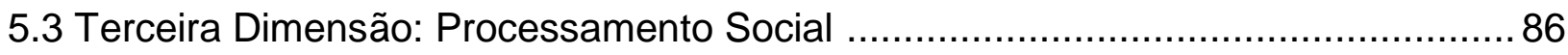

5.3.1 Processamento Social nos Grupos de Base: Primeira e Segunda Atividade....... 86

5.3.2 Processamento Social nos Grupos de Especialistas................................. 88

5.4 Avaliação dos Alunos Frente à Atividade Proposta ..................................... 90

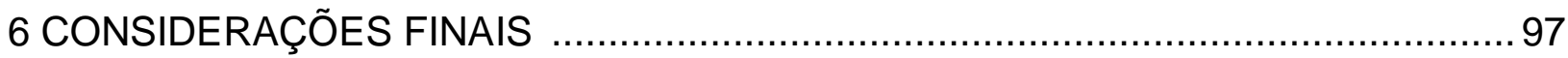

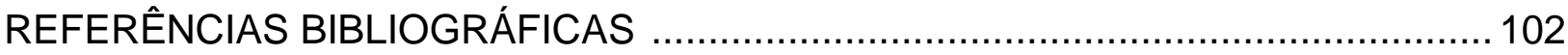

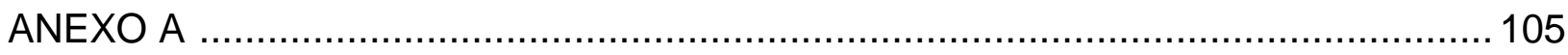

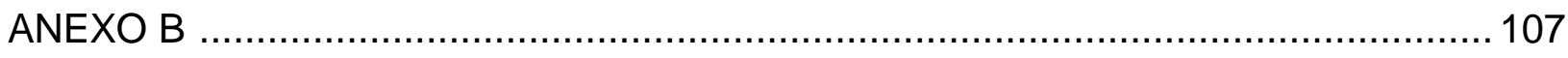

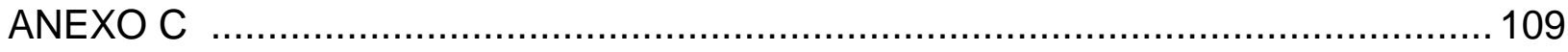

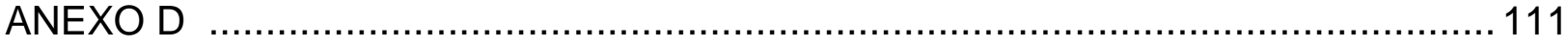

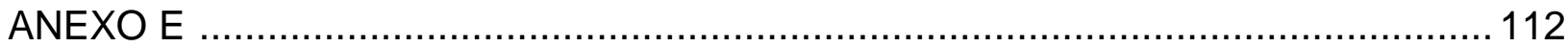

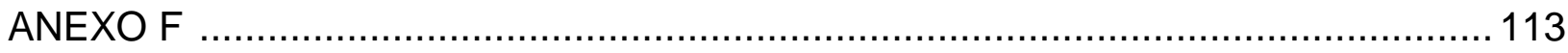

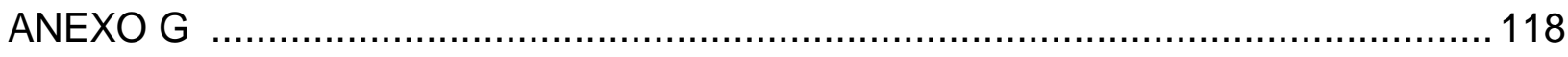

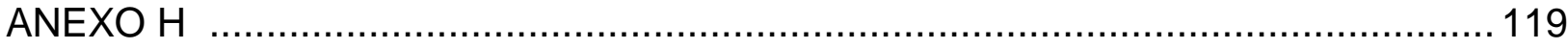




\section{INTRODUÇÃO}

Nas últimas décadas foram inúmeras as modificações realizadas nas grades curriculares dos cursos de graduação em Química no Brasil. No entanto, conforme destacam as Diretrizes Curriculares Nacionais para os Cursos de Química, muitas delas limitaram-se "à inclusão de novas disciplinas, extinção de outras ou apenas remanejamento das respectivas grades curriculares" (ZUCCO; PESSINE; ANDRADE, 1999).

Infelizmente, poucas foram as modificações capazes de atender à necessidade, advogada nas referidas Diretrizes, de criação de "um novo modelo de curso superior, que privilegie o papel e a importância do estudante no processo da aprendizagem, em que o papel do professor, de "ensinar coisas e soluções", passe a ser "ensinar o estudante a aprender coisas e soluções" (ZUCCO; PESSINE; ANDRADE, 1999).

No novo modelo, além da aprendizagem de conteúdos específicos, a escola tem a responsabilidade por uma formação mais geral do estudante, estando aí inseridas as questões que envolvem a cidadania. Nesse contexto, as estratégias didáticas de caráter cooperativo surgem como alternativa que pode auxiliar no alcance de tal formação, tornando o aluno parte mais ativa no processo de ensino aprendizagem. Tal 
participação está diretamente relacionada à interação existente entre os mesmos, assim como com os docentes. Contudo, concordamos com os irmãos Johnson e colaboradores quando afirmam:

As crianças não nascem sabendo instintivamente como interagir de forma
eficaz com os demais, as habilidades não aparecem magicamente quando se
necessita. Muitos alunos, tanto da escola primaria, quanto do colégio
secundário, carecem de habilidades sociais básicas tais como, a capacidade
de identificar corretamente os sentimentos dos outros e de conversar sobre.
Por isso muitos docentes que estruturam suas aulas cooperativamente
descobrem que seus alunos são incapazes de cooperar com os demais.
Porém, é precisamente nas situações cooperativas que as habilidades sociais
se tornam mais importante e idealmente, devem ser ensinadas (JOHNSON;
JOHNSON; HOLUBEC, 1999, p.79).

Visando o aprimoramento das habilidades sociais e tentando contribuir para o estabelecimento de um novo modelo de ensino, muitos pesquisadores (COCHITO, 2004; BARBOSA; JÓFILI, 2004; JOHNSON; JOHNSON; SMITH, 2007; VALVERDE; VIZA, 2008) vêm deixando seus registros sobre como trabalhar de forma cooperativa e propondo diretrizes para a realização de atividades dessa natureza. Os resultados por eles reportados nos levam a crer que a realização de atividades cooperativas pode favorecer o alcance de algumas das competências e habilidades apontadas como essenciais para a formação do químico, expressas nas Diretrizes Curriculares Nacionais (ZUCCO; PESSINE; ANDRADE, 1999).

Nessa perspectiva analisamos neste trabalho uma atividade didática, pautada nos princípios da aprendizagem cooperativa (JOHNSON; JOHNSON; HOLUBEC, 1999; JOHNSON; JOHNSON, 1989), assim como sua aceitação por alunos de graduação em Química matriculados em uma disciplina de comunicação científica.

Tendo em vista a natureza da temática explorada nesta dissertação, apresentamos a seguir alguns dos fundamentos da aprendizagem cooperativa. Cabe destacar que, com o intuito de situarmos o nosso trabalho na área de Pesquisa em Ensino de Ciências, buscamos na literatura investigações relacionadas à aprendizagem cooperativa no referido Ensino, o que nos forneceu subsídios para a 
apresentação também de um panorama sobre os estudos realizados, tanto no âmbito nacional quanto internacional.

\subsection{Aprendizagem Cooperativa}

Grandes contribuições para a divulgação da aprendizagem cooperativa são atribuídas aos autores David Johnson e Roger Johnson (1989). Uma característica chave que distingue este tipo de aprendizagem da aprendizagem tradicional é a sua natureza social, pois os estudantes interagem e compartilham suas ideias melhorando sua compreensão individual e mútua. Sua aprendizagem ocorre em um meio social particular, onde se desenvolvem habilidades intelectuais e sociais simultaneamente com o estabelecimento de inter-relações sociais.

Considerando que cooperar significa "trabalhar juntos para buscar objetivos comuns", nas atividades cooperativas os indivíduos buscam resultados que tragam benefícios para si mesmo e ao mesmo tempo para todos os outros integrantes do grupo. A aprendizagem cooperativa faz uso de pequenos grupos permitindo que os estudantes trabalhem juntos para melhorar seu próprio aprendizado e dos demais.

Seguindo a base teórica fornecida por Johnson, Johnson e Holubec (1991), para que o trabalho cooperativo seja funcional e produtivo, as seguintes condições precisam estar presentes no processo de ensino aprendizagem:

- Interdependência positiva: o sentimento do trabalho conjunto para um objetivo comum em que cada um se preocupa com a aprendizagem dos colegas. Esta pode ser estimulada estabelecendo-se interdependência positiva de objetivos (os estudantes estão cientes de que os seus objetivos de aprendizagem só serão alcançados se todos os membros do 
grupo alcançarem as suas metas); interdependência positiva de recompensa (cada estudante recebe uma mesma recompensa quando o grupo alcança seus objetivos); interdependência positiva de recursos (cada estudante dispõe de apenas uma parte dos recursos, da informação ou dos materiais necessários para concluir a tarefa estabelecida pelo professor); interdependência positiva de papéis (aos estudantes são atribuídos papéis complementares e inter-relacionados, com responsabilidades necessárias para que o grupo realize a tarefa estabelecida pelo professor);

- Responsabilidade individual: cada elemento do grupo sente-se responsável pela sua própria aprendizagem e pela dos colegas e contribui ativamente para o grupo. Esta pode ser estimulada com a formação de grupos pequenos de aprendizagem (quanto menor for o grupo, maior será a responsabilidade individual); com a realização de avaliações individuais com cada aluno e de avaliações aleatórias com o grupo, fazendo com que um aluno, escolhido pelo mecanismo de sorteio, apresente o trabalho do grupo; por meio da atribuição a um dos membros do grupo do papel de "verificador", o qual deve solicitar aos demais que expliquem as razões que fundamentam as respostas dadas à tarefa estabelecida pelo professor; criar condições para que os estudantes ensinem aos companheiros o que aprendem, prática denominada pelos autores de "explicação simultânea".

- Interação face-a-face: oportunidade de interagir com os colegas de modo a explicar, elaborar e relacionar conteúdos. Esta permite aos estudantes 
estimular e facilitar os esforços dos demais membros do grupo visando o alcance dos objetivos estabelecidos;

- Habilidades interpessoais: competências de comunicação, confiança, liderança, decisão e resolução de conflito. Toda a estruturação de atividades cooperativas baseia-se na premissa de que as habilidades sociais são a chave da produtividade do grupo (JOHNSON; JOHNSON; HOLUBEC, 1991, p.67). Quanto mais hábeis socialmente forem os alunos e mais atenção dispensem os professores ao ensino de habilidades sociais, maior será a possibilidade de sucesso do grupo;

- Processamento grupal: balanços regulares e sistemáticos do funcionamento do grupo e da progressão nas aprendizagens. Tem como objetivo avaliar quais ações do grupo se mostraram úteis e quais foram inúteis, conduzindo à elaboração de considerações sobre quais condutas devem ser mantidas ou alteradas.

O domínio e a aplicação dos referidos componentes permitem que o docente planeje e organize as atividades cooperativas formais, nas quais os alunos trabalham juntos por um dia ou por várias semanas realizando tarefas que podem implicar, por exemplo, na solução de um problema, redação de um relatório ou leitura de um livro. A princípio, cabem ao docente as seguintes atribuições: determinar os objetivos da atividade; tomar decisões prévias à sua realização, como distribuir os estudantes em grupos de trabalho, escolher os materiais didáticos, determinar a disposição de carteiras a ser adotada na sala etc; explicar a atividade e os objetivos almejados com a sua realização; colocar em funcionamento a atividade cooperativa propriamente dita; controlar a efetividade do trabalho realizado nos grupos e fazer intervenções quando necessário; avaliar a aprendizagem dos alunos, solicitando que o grupo faça uma 
avaliação sobre o seu desempenho, ou seja, o processamento grupal (JOHNSON; JOHNSON; HOLUBEC, 1999).

Dentre as decisões prévias à realização da atividade que o docente deve tomar, tem sido digna de nota a questão sobre como deve ser feita a distribuição dos alunos em grupos. É sugerido que grupos homogêneos são recomendáveis quando se procura promover o domínio de habilidades específicas ou o alcance de certos objetivos educativos. Porém, em geral, nos grupos heterogêneos os alunos dão e recebem explicações mais frequentemente e levam em conta uma perspectiva mais ampla ao discutir a questão em foco na tarefa solicitada pelo professor, o que acentua a profundidade da compreensão e a qualidade do raciocínio (JOHNSON; JOHNSON; HOLUBEC, 1999).

Além das atividades cooperativas formais, Johnson, Johnson e Holubec (1991) indicam ainda a possibilidade de realização de atividades cooperativas informais e em grupos de base. Os grupos de aprendizagem cooperativa informal são organizados de maneira que os estudantes se envolvam em discussões breves (três a cinco minutos) antes de começar uma explicação e após o seu término ou ao longo de toda uma explicação. A sua aplicação em aulas baseadas na apresentação de seminários ou em projeção de vídeos, por exemplo, pode fazer com que os alunos dispensem mais atenção ao assunto em foco.

Os grupos de base são formados por alunos que trabalham juntos com regularidade e por um longo prazo (duração mínima de um semestre). São constituídos de forma heterogênea por integrantes com distintos níveis de desempenho, motivação e disposição para a realização da tarefa. Considera-se que se os alunos souberem que seu grupo se manterá unido por um longo período, tenderão a encontrar maneiras de motivar e estimular os demais membros. Nessa perspectiva, é fundamental que 
acompanhem o progresso acadêmico de seus companheiros e procurem fazer com que seus objetivos sejam alcançados.

Diferentes métodos de aplicação, baseados nos preceitos da aprendizagem cooperativa, foram desenvolvidos e são objetos de extensa investigação (COCHITO, 2004), dentre os quais se destacam: a Instrução Complexa, o TGT (Teams-GamesTournament), o STAD (Student Teams Achievement Division) e o jigsaw. Cada método apresenta suas peculiaridades e a escolha de um ou de outro depende do objetivo do docente e da disciplina em que a atividade vai ser ministrada. Esta escolha é parte fundamental para o sucesso da aprendizagem cooperativa. Os métodos Instrução Complexa, TGT e STAD são sucintamente descritos a seguir, enquanto o método jigsaw, que fundamentou a elaboração da atividade didática descrita neste trabalho, será discutido com mais detalhadamente no capítulo Referencias Teóricos.

Instrução Complexa: neste tipo de atividade o professor também utiliza pequenos grupos de trabalho e proporciona uma interdependência positiva entre os alunos para maximizar a interação na resolução da tarefa. Nos grupos, os alunos auxiliam os outros integrantes. Na execução do método, primeiramente, o professor organiza os conceitos ou ideias centrais com a inclusão de uma grande questão. Na etapa posterior, o docente observa os alunos de maneira a proporcionar uma retroalimentação nas discussões, estimulando a participação de todos os membros do grupo. Por fim, avalia o sucesso da atividade com questionamentos direcionados à satisfação e ao aprendizado na realização da atividade.

TGT e STAD: desenvolvidos por Slavin (1983) o TGT (Teams-Games — Tournament) e o STAD (Student Teams Achievement Division) usam o fator motivacional como elemento facilitador do processo de ensino aprendizagem. Segundo Slavin, o rendimento aumenta com a aprendizagem cooperativa se e quando existir 
uma recompensa pelo trabalho de grupo e, ao mesmo tempo, se cada aluno for responsabilizado pela sua própria aprendizagem.

No TGT, os alunos são distribuídos em grupos heterogêneos e a função da equipe é assegurar que todos estejam preparados para um determinado torneio (competição), no qual serão feitas questões sobre determinada "matéria". Nestes torneios, cada aluno compete com colegas considerados do mesmo nível de rendimento, representando a equipe que o "treinou", isto é, a equipe heterogênea. As pontuações obtidas por cada aluno somam-se às pontuações médias da sua equipe.

O STAD é semelhante, mas em vez de torneios, cada aluno é avaliado individualmente através de um teste. A pontuação da equipe resulta da pontuação que é atribuída ao aluno, em função do seu desempenho anterior. Por exemplo, a um aluno que tenha melhorado o desempenho ao longo de um período são atribuídos 5 pontos, ao que mantém a mesma performance, 3 pontos; ao aluno que teve performance inferior, apenas 1 ponto. Desta forma, cada equipe para conseguir um bom resultado deverá "treinar" o melhor possível os seus membros, conseqüentemente todos são estimulados a melhorar o seu desempenho ao longo do tempo, qualquer que seja o seu ponto de partida. Em ambos os casos os resultados das equipes são obrigatoriamente divulgados, por exemplo, através de um cartaz em que todos podem observar a evolução.

Por fim, apresentamos brevemente as perspectivas teóricas subjacentes à aprendizagem cooperativa:

Teoria da interdependência social: tem suas origens ligadas a Kurt Kafka. Seus trabalhos, datados da década de vinte, propunham que os grupos eram conjuntos dinâmicos em que variavam a interdependência de seus integrantes. Suas ideias foram refinadas por pesquisadores como Kurt Lewis e Morton Deutsch. Ideias estas que 
foram ampliadas por pesquisadores como Johnson e Johnson e culminaram em uma perspectiva que supõem que a forma com que a interdependência social se estrutura define o tipo de interação entre os indivíduos, que por sua vez definirá os seus resultados. A interdependência positiva (cooperação) apresenta como resultado uma interação, na qual os alunos facilitam, com seus esforços, a aprendizagem dos demais. A interdependência negativa (competição) gera resultados de oposição. Nesta perspectiva, os alunos dificultam os trabalhos dos demais. Quando não há interdependência (individualismo) os alunos não interagem e trabalham de forma independente (JOHNSON; JOHNSON; HOLUBEC, 1999).

Teoria do desenvolvimento cognitivo, baseada nas obras de Piaget, Vigotsky e de outros teóricos a eles relacionados: Piaget sustentava que em ambientes cooperativos surgem conflitos sócio-cognitivos que geram desequilíbrios cognitivos que por sua vez podem gerar desenvolvimento cognitivo. Similarmente, Vygotsky parte da premissa que o conhecimento é uma ação social que ocorre quando há esforço para aprender, compreender e resolver problemas (JOHNSON; JOHNSON; HOLUBEC, 1999).

Teoria da aprendizagem comportamental: está centrada no impacto que o reforço e a recompensa exercem na aprendizagem. Está baseada nos trabalhos de pesquisadores com Skinner, Bandura e Homans, Thibaus e Kelley. Mais recentemente é defendida pelos trabalhos de Slavin que destaca a necessidade das recompensas grupais para motivar os estudantes a aprender (JOHNSON; JOHNSON; HOLUBEC, 1999). 


\subsection{Aprendizagem Cooperativa no Ensino de Ciências: Panorama das Pesquisas Nacionais e Internacionais}

Conforme mencionamos anteriormente, com o intuito de situarmos o nosso trabalho na área de Pesquisa em Ensino de Ciências, buscamos na literatura investigações relacionadas à aprendizagem cooperativa no referido Ensino. Inicialmente buscamos trabalhos publicados sobre o tema nas revistas que constam na área de avaliação do Programa QUALIS da Coordenação de Aperfeiçoamento de Pessoal de Nível Superior (Capes). O Programa QUALIS consiste em um conjunto de procedimentos utilizados pela Capes para estratificação da qualidade da produção intelectual dos programas de pós-graduação. Consultamos os periódicos QUALIS A, B1 e B2 da área 38 (Educação), que se relacionavam ao Ensino de Ciências, assim como os da área 46 (Ensino de Ciências e Matemática). No Anexo A encontram-se elencadas as revistas pesquisadas.

Também foram analisados os trabalhos apresentados em todas as edições dos ENPECs, encontro mais representativo da área de Ensino de Ciências no Brasil. Considerando que o nosso tema de investigação privilegia a área de Química consultamos ainda os trabalhos apresentados no Journal of Chemical Education (JCE), periódico de ampla penetração internacional.

A sistemática de busca e seleção dos periódicos se deu em três etapas, primeiramente pela verificação de menções à aprendizagem cooperativa, jigsaw ou termos similares, nos títulos dos trabalhos e palavras-chave; na segunda etapa os trabalhos pré-selecionados tiveram seus resumos lidos e deste conjunto selecionamos os que faziam referência a pesquisas ou a relatos de atividades planejadas com base 
nos preceitos da aprendizagem cooperativa; na terceira etapa os trabalhos selecionados foram lidos na íntegra.

Em seguida, os trabalhos foram analisados com relação à produção de acordo com a distribuição no tempo, com a área de pesquisa, com os níveis de escolaridade e com o foco temático privilegiado nos estudos.

\subsubsection{Aprendizagem Cooperativa: Âmbito Internacional}

$\mathrm{Na}$ Tabela 1.1 são apresentadas as revistas internacionais nas quais encontramos trabalhos sobre a temática, a quantidade de trabalhos localizada em cada uma delas e os respectivos períodos em que o levantamento foi realizado.

Tabela 1.1 - Revistas internacionais analisadas, quantidade de trabalhos localizados em cada uma delas e os respectivos períodos em que o levantamento foi realizado.

\begin{tabular}{lcc}
\hline Periódicos & Período & № de trabalhos \\
\hline Cell Biology Education & 2002 a 2010 & 3 \\
International Journal of Science Education & 1979 a 2010 & 4 \\
American Journal of Physics & 1993 a 2010 & 3 \\
Enseñanza de las Ciencias & 1998 a 2010 & 1 \\
Biochemistry and Molecular Biology Education & 2000 a 2010 & 2 \\
Revista Electrónica de Enseñanza de las Ciencias & 2002 a 2010 & 2 \\
Physics Education & 1966 a 2010 & 1 \\
Research in Science \& Technological Education & 1983 a 2010 & 1 \\
Total & & $\mathbf{1 7}$ \\
& & \\
\hline
\end{tabular}


A Tabela 1.2 apresenta a lista dos trabalhos publicados no âmbito internacional, agrupados de acordo com as revistas dispostas na Tabela 1.1.

Tabela 1.2 - Artigos sobre o tema aprendizagem cooperativa publicados em revistas internacionais.

№ $\quad$ Autor e Título

\section{Cell Biology Education}

1 TANNER, K.; CHATMAN, L. S.; ALLEN, D. Approaches to Cell 2003

Biology Teaching: Cooperative Learning in the Science

Classroom - Beyond Students Working in Groups

2 ARMSTRONG, N.; CHANG, S.; BRICKMAN, M. Cooperative 2007 Learning in Industrial-Sized Biology Classes

$3 \quad$ SEIFERT, K.; FENSTER, A.; DILTS, J. A.; TEMPLE, L. An Investigative, Cooperative Learning Approach to the General Microbiology Laboratory

\section{International Journal of Science Education}

4 OKEBUKOLA, P. A. The Problem of Large Classes in Science: An Experiment in Co-operative Learning

5 BANERJEE, A. C.; VIDYAPATI, T. J. Effect of Lecture and Cooperative Learning Strategies on Achievement in Chemistry in Undergraduate Classes

$6 \quad$ BARBOSA, $\quad$ R.; JOFILI, $\quad$ Z.; WATTS, $\quad$ M. $\quad$ Cooperating in 2004 Constructing Knowledge: Case Studies from Chemistry and Citizenship

7 THURSTON, A.; TOPPING, K. J.; TOLMIE, A.; CHRISTIE, D.; KARAGIANNIDOU, E. ; MURRAY, P. Cooperative Learning in Science: Follow-up from Primary to High School

\section{American Jounal of Physics}

8 HELLER, P.; KEITH, R.; ANDERSON, S. Teaching Problem Solving Through Cooperative Grouping. Part 1: Group Versus Individual Problem Solving

9 HOLLABAUGH, M. Teaching Problem Solving Through Cooperative Grouping. Part 2: Designing Problems and Structuring Groups

10 SAMIULLAH, M. Effect of in-Class Student-Student Interaction on the Learning of Physics in a College Physics Course

\section{Enseñanza de las Ciencias}

11 VALVERDE, G. J.; VIZA, A. M. L. Optimización Metodológica de Entornos Telemáticos Cooperativos (BSCW y SINERGEIA) como recursos didácticos de la química en la producción de hipermedia

\section{Biochemistry and Molecular Biology Education}

12 ANDERSON, W. L.; MITCHELL, S. M.; OSGOOD, M. P. 2005 Comparison of Student Performance in Cooperative Learning and Traditional Lecture-Based Biochemistry Classes

13 FERNÁNDEZ-SANTANDER, A. Cooperative Learning 2008 Combined with Short Periods of Lecturing

\section{Revista Electrónica de Enseñanza de las Ciencias}




\begin{tabular}{|c|c|c|}
\hline 14 & $\begin{array}{l}\text { GARCÍA, A. G.; TUÑÓN, M. J. I. El Ciclo Reflexivo Cooperativo: } \\
\text { un Modelo Didáctico para la Enseñanza de las Ciencias }\end{array}$ & 2004 \\
\hline 15 & $\begin{array}{l}\text { VALVERDE, G. J.; JIMÉNEZ, R. L.; ANNA LLITJÓS VIZA, A. L. } \\
\text { Los Niveles de Abertura en las Prácticas Cooperativas de } \\
\text { Química }\end{array}$ & 2005 \\
\hline \multicolumn{3}{|c|}{ Physics Education } \\
\hline 16 & $\begin{array}{l}\text { MILLS, D.; MCKITTRICK, B. MULHALL, P.; FETERIS, S. CUP: } \\
\text { Cooperative Learning that Works }\end{array}$ & 1999 \\
\hline \multicolumn{3}{|c|}{ Research in Science \& Technological Education } \\
\hline 17 & $\begin{array}{l}\text { DOYMUS, K. } \quad \text { Teaching } \\
\text { Jigsaw Cooperative Learning }\end{array}$ & 2008 \\
\hline
\end{tabular}

\section{A produção e sua distribuição no tempo}

Com base no levantamento bibliográfico realizado, constatamos que o número de trabalhos publicados com questões referentes ao tema em foco aumentou significativamente a partir da década de noventa.

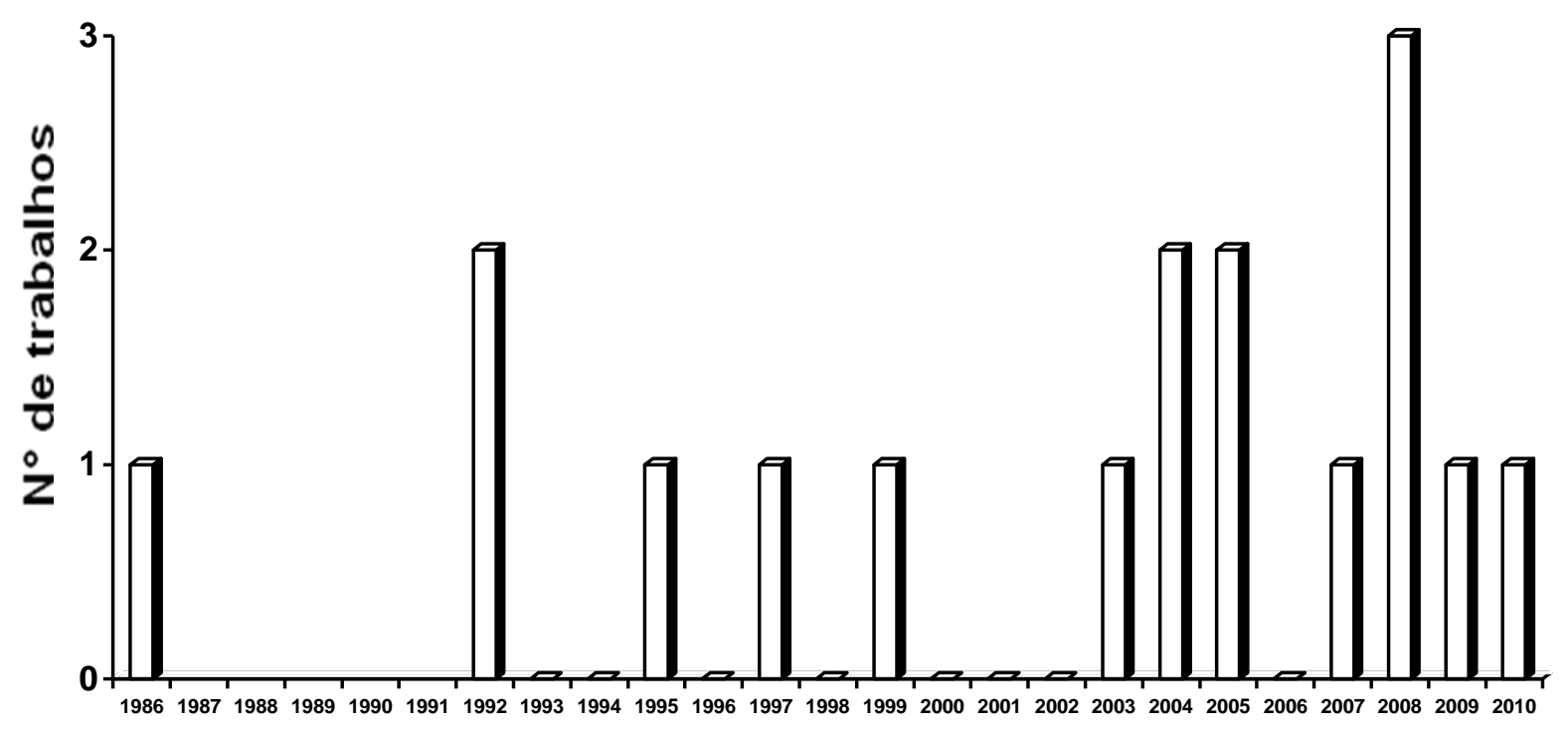

Figura 1.1 - Quantidade de trabalhos localizados nas revistas internacionais.

Podemos inferir com base na Figura 1.1 que o primeiro trabalho encontrado nos periódicos analisados sobre a temática foi publicado em 1986 no International Journal of Science Education, sendo esta a única publicação da década de oitenta. O tema voltou a ser abordado em 1992, tendo sido localizados cinco trabalhos na década de 
90, o que mostra a relevância que o assunto vem ganhando no decorrer do tempo. De fato, no período de 2000 a 2009 foram publicados onze artigos.

Interessante, além do volume de publicações, é perceber que nesse período os trabalhos foram publicados em diversas áreas, abrangendo revistas de Educação em Física, Química e Ciências, revelando que a aprendizagem cooperativa se adéqua a diversas áreas de ensino.

O ano de 2010 também foi analisado e foi encontrado um trabalho sobre o tema, entretanto, alguns periódicos ainda não publicaram todos seus volumes, sendo assim os dados referentes a este ano podem ser alterados posteriormente.

\section{A produção e sua distribuição de acordo com os níveis de escolaridade}

Foram considerados os níveis fundamental, médio, superior e geral na classificação dos trabalhos quanto ao nível de escolaridade. Para identificar o nível escolar ao qual se relacionam os trabalhos, levamos em consideração os sujeitos participantes da pesquisa e a descrição das atividades educacionais. Foram classificados na categoria geral os trabalhos que abordam os vários níveis escolares de forma genérica ou não especifica, que não apresentaram em seus relatos direcionamento para nenhum nível escolar, podendo assim ser de interesse do público em geral.

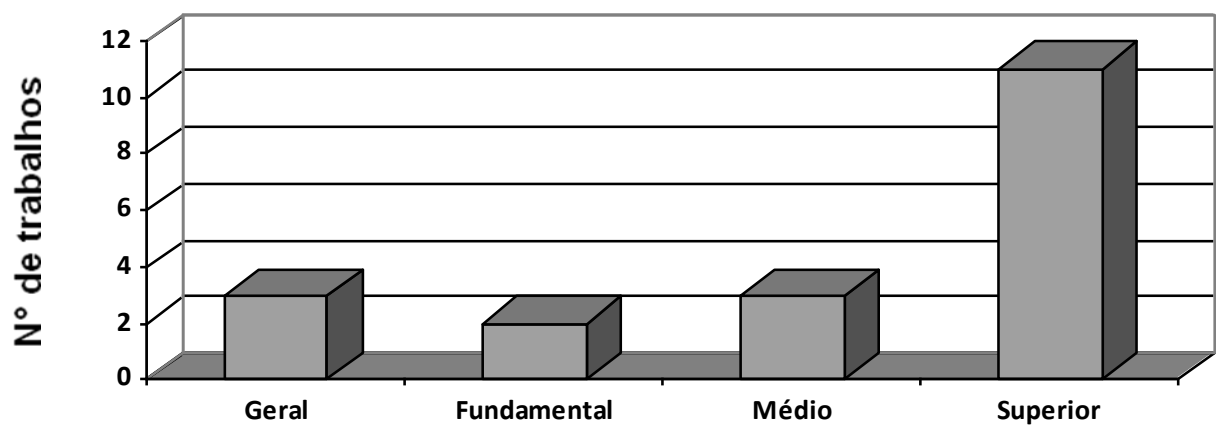

Figura 1.2 - Distribuição dos trabalhos de acordo com os níveis de escolaridade. 
Conforme ilustra a Figura 1.2, o ensino superior é o nível de escolaridade em que mais experiências com aprendizagem cooperativa foram reportadas, dos dezenoves trabalhos, onze se relacionam ao ensino superior, representando $58 \%$ do total. O elevado número de trabalhos pode ser justificado devido ao fato da aprendizagem cooperativa possibilitar um ambiente propício para o desenvolvimento de habilidades interpessoais, cada vez mais exigidas pelo mercado de trabalho. Assim, esta, em geral, é aplicada neste nível de ensino com o objetivo de desenvolver tais habilidades (BANERJEE; VIDYAPATI, 1997; ARMSTRONG; CHANG; BRICKMAN, 2007). Ademais, a aprendizagem cooperativa se apresenta como alternativa às aulas estritamente expositivas, usuais em muitas universidades, assim como para aplicação em turmas numerosas (SAMIULLAH, 1995; FERNÁNDEZ-SANTANDER, 2008; SEIFERT; FENSTER; DILTS, 2009).

Os níveis de escolaridades fundamental e médio foram representados por cinco trabalhos, sendo dois relacionados ao ensino fundamental e três ao ensino médio. Podemos especular que a pequena quantidade de trabalhos se justifica pelas dificuldades apontadas pelos docentes em trabalhar com grupos, já que esse tipo de atividade exige uma preparação maior para aplicação do que as metodologias tradicionais. Uma atividade cooperativa não implica simplesmente em organizar os alunos em grupos, exige uma preparação do docente. Esta dificuldade é resumida por Johnson, Johnson e Holubec (1999) da seguinte forma: "muitas vezes, os docentes que utilizam aprendizagem cooperativa nos dizem "Porém não digam que é fácil". Sabemos que não é, pode se levar anos para se tornar um especialista, existe muita pressão para que ensinemos como os demais, pressão até mesmo por parte dos alunos, que sem costume de trabalhar juntos, podem preferir um trabalho individual ou 
competitivo". Entretanto, é necessário vencer tais barreiras e explorar mais a abordagem cooperativa nestes níveis de ensino.

$\mathrm{Na}$ categoria geral foram classificados três trabalhos, sendo um do tipo bibliográfico (TANNER; CHATMAN; ALLEN, 2003), um voltado para análise de um programa de computador que pode ser usado em qualquer nível para facilitar a interação cooperativa entre os alunos (VALVERDE; VIZA, 2008) e por último um trabalho que envolveu alunos de vários níveis escolares (BARBOSA; JÓFILI; WATTS, 2004). Cabe destacar que trabalhos voltados para avaliação de programas de computador, nos quais os sujeitos trabalham em um contexto cooperativo, são comuns, mas usualmente são publicados em periódicos da área de Computação, que não foram incluídos no nosso levantamento bibliográfico.

\section{A produção e sua distribuição de acordo com a área investigada}

No que diz respeito à área investigada, conforme ilustra a Figura 1.3, cinco dos trabalhos são concernentes à área de Química, três à área de Ciências, três à área de Biologia e quatro à área de Física. Na categoria geral foram localizados dois trabalhos, estes foram classificados nesta categoria, pois não apresentam direcionamento para nenhuma área de forma especifica.

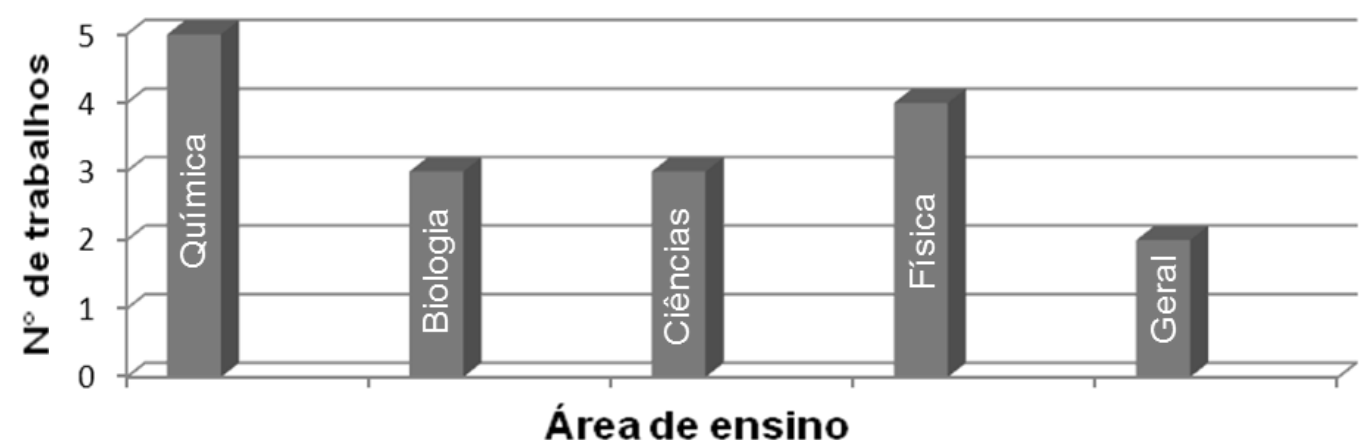

Figura 1.3 - Classificação dos trabalhos de acordo com a área investigada. 
Analisando os dados de nível de escolaridade e área de ensino, percebe-se que os trabalhos realizados na área de Química e Física foram todos realizados no ensino superior e dois dos trabalhos de Biologia são também voltados ao ensino superior. Entretanto, muitos pesquisadores relatam que a aprendizagem cooperativa deve ser introduzida o quanto antes na vida dos estudantes (COCHITO, 2004; BARBOSA; JÓFILI, 2004; JOHNSON; JOHNSON; SMITH, 2007).

Neste contexto fica evidente que os trabalhos voltados para área de Ciências são de suma importância já que a inserção de conceitos e hábitos cooperativos nos alunos nos primeiros anos de sua formação é relevante.

Os resultados indicam que a temática vem sendo investigada em todas as áreas de Ciências, existindo ainda trabalhos de caráter interdisciplinar, que abrangem também áreas distintas, com destaque para a área de Computação. Este fato é recorrente uma vez que as novas tecnologias, quando usadas em parceria com a aprendizagem cooperativa, conduzem, usualmente, experiências que podem ser exploradas em diferentes dimensões.

\section{A produção e sua distribuição de acordo com o foco temático}

A análise dos trabalhos internacionais permitiu a determinação dos focos temáticos mais recorrentes que são descritos brevemente a seguir.

- Aprendizagem cooperativa e suas possibilidades: trabalhos que discutem as contribuições acadêmicas provenientes do uso de estratégias baseadas nos preceitos da aprendizagem cooperativa; 
- Aprendizagem cooperativa e suas estratégias específicas: trabalhos que discutem o uso de um método específico de aprendizagem cooperativa, como jigsaw, STAD (Student Teams Achievement Division), entre outros;

- Aprendizagem cooperativa em parceria com outras metodologias: trabalhos que discutem as contribuições da aprendizagem cooperativa quando usada em parceria com outras metodologias de ensino/recursos didáticos;

- Aprendizagem cooperativa apresentada em perspectiva teórica: trabalhos que apresentam considerações exclusivamente teóricas sobre a aprendizagem cooperativa.

A Tabela 1.3 apresenta a classificação dos trabalhos encontrados em âmbito internacional de acordo com o foco temático. Todos os trabalhos abaixo têm numeração correlata aos apresentados na Tabela 1.2.

Tabela 1.3 - Classificação dos trabalhos de acordo com o foco temático.

\section{$\mathbf{N}^{\circ} \quad$ Foco temático/Abordagem}

1. Aprendizagem cooperativa apresentada em perspectiva teórica

2. Aprendizagem cooperativa e suas possibilidades

3. Aprendizagem cooperativa em parceria com outras estratégias

4. Aprendizagem cooperativa e suas possibilidades

5. Aprendizagem cooperativa e suas possibilidades

6. Aprendizagem cooperativa e suas estratégias específicas

7. Aprendizagem cooperativa e suas possibilidades

8. Aprendizagem cooperativa e suas possibilidades

9. Aprendizagem cooperativa e suas possibilidades

10. Aprendizagem cooperativa e suas possibilidades

11. Aprendizagem cooperativa em parceria com outras estratégias

12. Aprendizagem cooperativa e suas possibilidades

13. Aprendizagem cooperativa em parceria com outras estratégias

14. Aprendizagem cooperativa e suas possibilidades

15. Aprendizagem cooperativa e suas possibilidades

16. Aprendizagem cooperativa e suas possibilidades

17. Aprendizagem cooperativa e suas estratégias específicas 


\section{Aprendizagem cooperativa e suas possibilidades}

Dentre os dezessete trabalhos internacionais, onze tratam de experiências voltadas à análise das possibilidades da aprendizagem cooperativa. Verificando os objetivos e os resultados dos trabalhos, podemos fazer as seguintes inferências: Os trabalhos 7, 8, 9, 14, 15 e 16 apontaram a adoção da aprendizagem cooperativa como promotora de um ambiente em que os alunos produzem melhores respostas aos problemas propostos e, consequentemente, têm seu desempenho acadêmico melhorado. Nesse contexto, nos trabalhos 7, 8, 9 e 15 os autores destacaram que o melhor desempenho acadêmico dos alunos relacionou-se diretamente à interação proporcionada pela atividade, que criou uma interdependência positiva fazendo com que estes trabalhassem pensando no grupo como um todo.

Os trabalhos 14 e 16 apontaram como ponto forte da atividade a aprovação dos alunos que dela participaram. Também relacionaram esta aprovação com o fato da atividade criar um ambiente mais motivador para os alunos. $\mathrm{O}$ trabalho 10 é digno de nota, pois o autor deixa claro que as atividades cooperativas geraram ganhos em habilidades sociais para os alunos, mas não melhoram os seus resultados acadêmicos, de forma distinta dos trabalhos citados anteriormente.

Os trabalhos 2 e 4 apresentaram como objetivo avaliar as contribuições da aprendizagem cooperativa em turmas numerosas, chegando a resultados que apontam para uma melhoria no desempenho dos alunos. Os autores indicam que quando os alunos participam de aulas em pequenos grupos cooperativos o conhecimento a respeito do material didático é mais completo do que em aulas tradicionais.

No trabalho 12 os resultados obtidos foram considerados positivos, entretanto, não existe uma análise clara sobre os fatores que levaram a estes resultados. 0 
próprio autor fez questão de afirmar que uma análise mais aprofundada precisa ser feita futuramente.

No trabalho 5 diferentemente dos demais, os autores afirmaram que as atividades cooperativas não ajudaram a melhorar o desempenho dos alunos. Cabe ressaltar que os mesmos deixaram claro que, apesar de não terem encontrado pontos de melhoria nas atividades, também não encontraram pontos negativos que desqualificassem a atividade cooperativa. Ademais, os autores admitiram que suas investigações foram pontuais e que para um melhor resultado seria interessante a realização de novas pesquisas.

\section{Aprendizagem cooperativa e suas estratégias específicas}

Os trabalhos 6 e 17 foram classificados neste foco temático, sendo o método jigsaw objeto central das análises. Como resultado da utilização da estratégia os autores apontam como ponto forte o desempenho acadêmico dos alunos. Os autores do trabalho 6 também enfatizam que a aplicação do método é capaz de formar alunos mais preocupados com questões de cidadania e pode ser usado em todos os níveis escolares.

\section{Aprendizagem cooperativa em parceria com outras estratégias}

Os trabalhos 3, 11 e 13 foram classificados neste foco temático. No trabalho 3 são discutidos os benefícios da utilização da aprendizagem cooperativa em aulas laboratoriais e seus autores apresentam como resultado uma boa aceitação por parte dos alunos. No trabalho 11 são discutidos benefícios decorrentes do uso de recursos 
computacionais associados a técnicas cooperativas. Com o uso das novas tecnologias, a interação entre os alunos se estendeu para atividades extraclasse, enriquecendo a aquisição de conhecimentos. Ademais, os autores acreditam que o uso combinado da aprendizagem cooperativa com recursos computacionais melhorou o desenvolvimento acadêmico dos alunos.

No trabalho 13 os autores apresentaram uma atividade que combinava atividades cooperativas com aulas tradicionais, os resultados apontados demonstram que os alunos participantes da atividade combinada melhoraram seus resultados acadêmicos, se comparados com os alunos que participaram de aulas tradicionais. Apontaram ainda uma boa aceitação dos alunos frente ao método utilizado, nele os alunos se mostraram mais satisfeitos em participar do processo de ensino aprendizagem.

\section{Aprendizagem cooperativa apresentado em perspectiva teórica}

O trabalho 1 foi o único classificado nesta categoria, nele os autores recorrem à análise de diversos artigos e fazem uso dos resultados encontrados para recomendar a utilização da aprendizagem cooperativa.

A seguir apresentamos os trabalhos publicados sobre a temática no periódico JCE (Tabela 1.4). Estes foram analisados segundo os focos temáticos descritos anteriormente. Pretendemos assim oferecer ao leitor um panorama mais abrangente sobre a aprendizagem cooperativa especificamente na área na qual se insere esta dissertação, a área de Química. Cabe ressaltar que o periódico foi analisado no período de 1999 a 2010, sendo encontrados 24 trabalhos. 
Tabela 1.4 - Artigos sobre o tema aprendizagem cooperativa publicados no JCE.

№ $\quad$ Autor e Titulo

Ano de

Publicação

JCE

18 SMITH, M. E.; HINCKLEY, C. C.; VOLK, G. L. Cooperative Learning 1991 in the Undergraduate Laboratory

19 COOPER, M. M. Cooperative Learning: An Approach for Large 1995 Enrollment Courses

20 ANDERSON, J. S.; HAYES, D. M.; WERNER, T. C. The Chemical

1995

Bond Studied by IR Spectroscopy in Introductory Chemistry: An

Exercise in Cooperative Learning

21 FLEMING, F. F. No Small Change: Simultaneously Introducing cooperative Learning and Microscale Experiments in an

Organic Lab Course

22 R. C. DOUGHERTY, R. C.; BOWEN, C. W.; BERGER, T.; REES, W.; MELLON, E. K.; PULLIAM, E. Cooperative Learning and Enhanced Communication: Effects on Student Performance, Retention, and Attitudes in General Chemistry

23 BIRK, J. P.; KURTZ, M. J. Using Cooperative Learning Techniques to Train New Teaching Assistants

24 WRIGHT, J. C. Authentic Learning Environment in Analytical Chemistry: Using Cooperative Methods and Open-Ended Laboratories in Large Lecture Courses

25 FELDER, R. M. Active-Inductive-Cooperative Learning: An 1996 Instructional Model for Chemistry?

26 NURRENBERN, S. C. ; ROBINSON, W. R. Cooperative Learning: A 1997 Bibliography

27 DOUGHERTY, R. C. Grade/Performance Contracts, Enhanced Communication, Cooperative Learning and Student Performance in Undergraduate Organic Chemistry

28 TOWNS, M. H. How Do I Get My Students to Work Together? 1998 Getting Cooperative Learning Started

29 PENCE, L. E. Cooperative Electronic Mail: Effective Communication 1999 Technology for Introductory Chemistry

30 KOVAC, J. Student Active Learning Methods in General Chemistry 1999

31 PAULSON, D. R. Active Learning and Cooperative Learning in the 1999 Organic Chemistry Lecture Class

32 TOWNS, M. H.; KREKE, K.; FIELDS, A. An Action Research 2000 Project: Student Perspectives on Small-Group Learning in

Chemistry

33 BOWEN, C. W. A Quantitative Literature Review of Cooperative 2000 Learning: Effects on High School and College Chemistry Achievement

34 HAGEN, J.P. Cooperative Learning in Organic II. Increased 2000 Retention on a Commuter Campus

35 CARPENTER, S. R.; MCMILLAN, T. Incorporation of a Cooperative 2003 Learning Technique in Organic Chemistry 


\begin{tabular}{lll}
\hline 36 & $\begin{array}{l}\text { SEETHARAMAN, M.; MUSIER-FORSYTH, K. Does Active Learning } \\
\text { through an Antisense Jigsaw Make Sense? }\end{array}$ & 2003 \\
\hline 37 & $\begin{array}{l}\text { GIANCARLO, L. C.; SLUNT, K. M. The Dog Ate My Homework: A } \\
\text { Cooperative Learning Project for Instrumental Analysis }\end{array}$ & 2004 \\
\hline 38 & $\begin{array}{l}\text { EILKS, I. Experiences and Reflections about Teaching Atomic } \\
\text { Structure in a Jigsaw Classroom in Lower Secondary School } \\
\text { Chemistry Lessons }\end{array}$ & 2005 \\
\hline 39 & $\begin{array}{l}\text { DOYMUS, K. Effects of a Cooperative Learning Strategy on } \\
\text { Teaching and Learning Phases of Matter and One-Component } \\
\text { Phase Diagrams }\end{array}$ & 2007 \\
\hline 40 & $\begin{array}{l}\text { LYON, D. C.; LAGOWSKI, J. J. Effectiveness of Facilitating Small- } \\
\text { Group Learning in Large Lecture Classes }\end{array}$ & 2008 \\
\hline 41 & DAVIS-MCGIBONY, C. M. Protein-Sequencing Jigsaw & 2010 \\
\hline
\end{tabular}

A quantidade de trabalhos presentes na Tabela 1.4 sugere que 0 interesse sobre a temática é considerável na área de Química. De fato, 24 trabalhos foram publicados nas duas últimas décadas, o que também mostra a atualidade do tema em foco.

Com relação ao nível de ensino considerado nos trabalhos, a maioria deles é direcionada ao ensino superior, representando mais de $80 \%$ do total (21 trabalhos). Somente o trabalho 38 tratou da questão no ensino médio. Os demais foram classificados na categoria geral, sendo dois do tipo que abrange a temática em perspectiva teórica, trabalhos 26 e 28 .

\section{A produção e sua distribuição de acordo com o foco temático}

A Tabela 1.5 apresenta a classificação dos trabalhos encontrados no periódico JCE de acordo com o foco temático. Todos os trabalhos apresentam numeração correlata aos apresentados na Tabela 1.4. 
Tabela 1.5 - Classificação dos trabalhos de acordo com o foco temático.

\section{$\mathbf{N}^{\circ}$ Foco temático/Abordagem}

18. Aprendizagem cooperativa e suas estratégias específicas

19. Aprendizagem cooperativa apresentada em perspectiva teórica

20. Aprendizagem cooperativa em parceria com outras metodologias

21. Aprendizagem cooperativa em parceria com outras metodologias

22. Aprendizagem cooperativa e suas possibilidades

23. Aprendizagem cooperativa e suas possibilidades

24. Aprendizagem cooperativa em parceria com outras metodologias

25. Aprendizagem cooperativa e suas possibilidades

26. Aprendizagem cooperativa apresentada em perspectiva teórica

27. Aprendizagem cooperativa e suas possibilidades

28. Aprendizagem cooperativa apresentada em perspectiva teórica

29. Aprendizagem cooperativa em parceria com outras metodologias

30. Aprendizagem cooperativa em parceria com outras metodologias

31. Aprendizagem cooperativa em parceria com outras metodologias

32. Aprendizagem cooperativa e suas possibilidades

33. Aprendizagem cooperativa apresentada em perspectiva teórica

34. Aprendizagem cooperativa em parceria com outras metodologias

35. Aprendizagem cooperativa e suas estratégias específicas

36. Aprendizagem cooperativa e suas estratégias específicas

37. Aprendizagem cooperativa em parceria com outras metodologias

38. Aprendizagem cooperativa e suas estratégias específicas

39. Aprendizagem cooperativa e suas estratégias específicas

40. Aprendizagem cooperativa e suas possibilidades

41. Aprendizagem cooperativa e suas estratégias específicas

\section{Aprendizagem cooperativa e suas possibilidades}

Dos vinte e quatro trabalhos encontrados seis tratavam de analisar as possibilidades geradas com o uso da aprendizagem cooperativa.

Os trabalhos de número 25, 27, 32 e 40 apontaram a aprendizagem cooperativa como uma atividade que propicia um ambiente em que os alunos produzem melhores respostas e por isso têm seu desempenho aperfeiçoado, entretanto os resultados foram justificados com o uso de argumentos diferenciados. Nos trabalhos 25 e 32 o melhor desempenho é atribuído ao grau de interação gerado pela atividade; no trabalho 40 os autores apontam um maior domínio sobre o material didático como fato mais relevante; já no trabalho 22 os autores sugerem que o 
resultado satisfatório dos alunos está diretamente relacionado ao grau de organização do trabalho em grupo. Assim afirmam que quanto mais estruturada é a atividade, melhores são os resultados.

O trabalho 23 destaca que os benefícios que a aprendizagem cooperativa traz aos alunos pode se estender aos docentes. É importante ressaltar que nas atividades descritas neste artigo a aprendizagem cooperativa é utilizada na preparação de futuros docentes e estes apresentaram melhores desempenhos após terem participado das atividades cooperativas.

Aprendizagem cooperativa e suas estratégias específicas

Foram encontrados 6 trabalhos, 18, 35, 36, 38, 39 e 41, com este foco temático, sendo a estratégia mais recorrente a do tipo jigsaw, usada 5 vezes. Além dela, ainda, encontramos o STAD, usado como estratégia no trabalho 35 . Como resultado da utilização das estratégias os autores apontam como ponto forte do jigsaw o resultado acadêmico dos alunos, de acordo com os cinco trabalhos o desempenho dos mesmos melhorou. Os autores do trabalho 18 fizeram questão de frisar que além do rendimento médio da turma ter sido melhor, os melhores resultados vêm dos alunos de baixo rendimento. No trabalho 36 o autor salienta que a estratégia é facilmente adaptável a diversos conteúdos didáticos e chama atenção para o fato do conhecimento dos alunos, na perspectiva de aplicação do método, ser desenvolvido de forma mais ativa.

Com relação à aplicação do método $S T A D$, o autor destaca, além da melhoria no desempenho dos alunos, uma boa aceitação da atividade por parte dos mesmos. 
Aprendizagem cooperativa em parceria com outras metodologias

Foram classificados neste foco temático os trabalhos 20, 21, 24, 29, 30, 31, 34 e 37 , dentre os quais destaca-se o trabalho 29 que descreve os ganhos proporcionados pelo uso de recursos computacionais associados a técnicas cooperativas.

Os trabalhos 20, 21, 24 e 37 apresentaram atividades cooperativas sendo usadas em parceria com aulas experimentais em laboratório de Química. Nestas atividades combinadas, os alunos tiveram resultados acadêmicos melhores, decorrentes da maior interação estabelecida entre eles. Os autores do artigo 24 destacam ainda o fato de atividade ter contado com boa aprovação por parte dos alunos.

Os trabalhos 30, 31 e 34 descrevem atividades cooperativas associadas com a tomada de notas de aula, uso de estratégias de leitura e aplicação de tarefas de casa, respectivamente. Os resultados apresentados em todos os trabalhos mostraram um avanço acadêmico que culminou em menor retenção de alunos nos cursos em questão.

Aprendizagem cooperativa apresentada em perspectiva teórica

Os trabalhos 19, 26, 28 e 33 foram classificados neste foco. O trabalho 19 apresenta uma análise de vários fatores que sugerem a aprendizagem cooperativa como alternativa para salas com número elevado de alunos em detrimento das aulas tradicionais. O trabalho 26 traz um levantamento de trabalhos publicados nos últimos anos sobre aprendizagem cooperativa. No entanto, estes não são analisados.

O artigo 28 busca descrever a aprendizagem cooperativa assim como suas estratégias específicas. Já o artigo 33 recorre à análise de diversos artigos e fazendo 
uso dos resultados encontrados recomenda a utilização das estratégias de aprendizagem cooperativa.

\subsubsection{Aprendizagem Cooperativa: Âmbito Nacional}

Na Tabela 1.6 são apresentadas as revistas nacionais nas quais encontramos trabalhos sobre a temática, a quantidade de trabalhos localizada em cada uma delas e os respectivos períodos em que o levantamento foi realizado.

Tabela 1.6 - Revistas nacionais analisadas, quantidade de trabalhos localizados em cada uma delas e os respectivos períodos em que o levantamento foi realizado.

\begin{tabular}{lcc} 
Periódicos & Período & № de trabalhos \\
\hline $\begin{array}{l}\text { Revista Brasileira de Pesquisa em } \\
\text { Educação em Ciências }\end{array}$ & 2001a 2010 & 1 \\
Educação e Pesquisa & 1975 a 2010 & 1 \\
Experiência em Ensino de Ciência & 2006 a 2010 \\
Revista Química Nova na Escola & 1995 a 2010 & 1 \\
Total & & 1 \\
\hline
\end{tabular}

A Tabela 1.7 apresenta os trabalhos publicados nas revistas mencionadas, em ordem cronológica.

Tabela 1.7 - Artigos sobre o tema aprendizagem cooperativa publicados em revistas nacionais.

\begin{tabular}{llcc}
\hline № Autor e Titulo & $\begin{array}{c}\text { Ano de } \\
\text { Publicação }\end{array}$ \\
\hline Ciência e Educação & 2004 \\
\hline $1 \quad$ BARBOSA, R. M. N.; JÓFILI, Z. M. S. Aprendizagem Cooperativa & \\
e Ensino de Química - Parceria que Dá Certo & \\
\hline Experiência em Ensino de Ciência & & \\
\hline 2 & CAVALHEIRO, P.; DEL PINO, J. C.. Aprendizagem e & 2007 \\
& $\begin{array}{l}\text { Cooperação em Atividades de Monitoria para o Ensino de } \\
\text { Ciências no Nível Fundamental }\end{array}$ \\
\hline
\end{tabular}




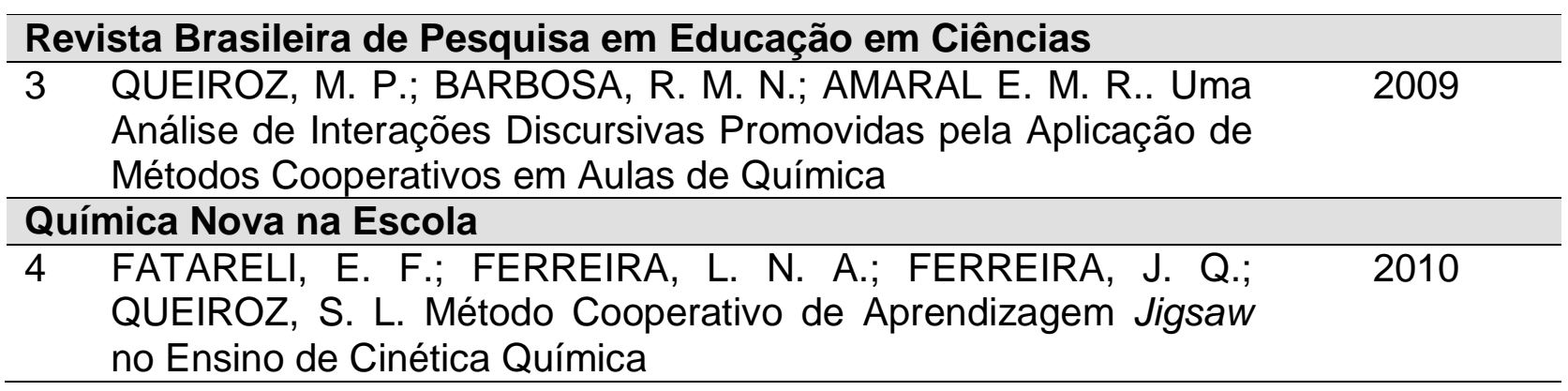

A Tabela 1.8 apresenta os trabalhos encontrados em todas as edições dos ENPECs, em ordem cronológica.

Tabela 1.8 - Trabalhos completos apresentados nos ENPECs sobre o tema aprendizagem cooperativa.

VI ENPEC - Florianópolis, 2007

5 Aprender Ciências em Grupo: O Que os Alunos

Pensam?

\section{Autores}

GUEDES, M.G.M.;

BARBOSA, R.M.N.;

JÓFILI, Z.M.S.

\section{ENPEC - Florianópolis, 2009}

6 Cooperação ou Competição? Avaliação de uma Estratégia Lúdica de Ensino de Biologia para Estudantes do Ensino Médio

MELIM, L.M.C.;

SPIEGEL, C.N.;

ALVES, G.G.; LUZ, M.R.M.P.

7 Aprendizagem Cooperativa no Ensino de Química: SILVA, A. J.; GAUCHE uma Proposta de Abordagem em Sala de Aula

R.

\section{A produção e sua distribuição no tempo}

Com base no levantamento bibliográfico realizado, observamos que questões ligadas à aprendizagem cooperativa são ainda pouco exploradas em âmbito nacional. Na Figura 1.4 apresentamos a frequência de trabalhos localizados nas revistas e nos anais dos ENPECs, de acordo com os períodos especificados nas Tabelas 1.6, $1.7 \mathrm{e}$ 1.8. 


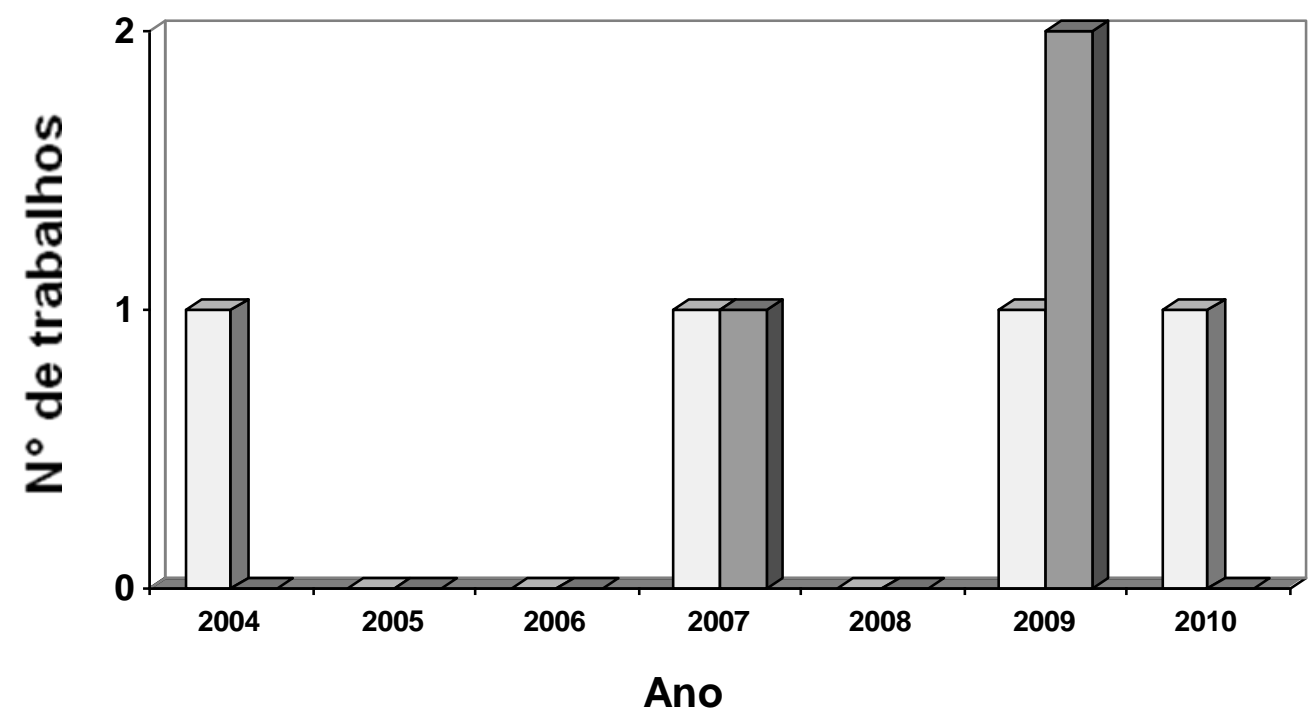

Revistas

ENPEC

Figura 1.4 - Quantidade de trabalhos publicados nas revistas e nos anais dos ENPECs.

Com relação às revistas analisadas, encontramos quatro publicações, sendo a primeira referente ao ano de 2004. Não foram publicados artigos em 2005, 2006 e 2008 e em 2007, 2009 e 2010 ocorreu uma publicação por ano. Embora exista apenas uma publicação no ano de 2010, alguns periódicos ainda não publicaram todos seus volumes, assim os dados ainda podem sofrer alterações.

No que diz respeito aos trabalhos referentes aos ENPECs, a abordagem do tema só ocorreu nas duas ultimas edições do evento. Em 2007 um único trabalho foi apresentado e em 2009 a produção dobrou, com a apresentação de dois trabalhos.

Pode-se inferir a partir dos resultados ilustrados na Figura 1.4 que, embora tímidamente, o tema vem sendo abordado de forma crescente, tendo seu máximo em 2009 com a presença de três trabalhos. Os dados também sugerem a atualidade do tema e que suas possibilidades educacionais ainda não foram significativamente exploradas no contexto nacional. 


\section{A produção e sua distribuição de acordo com as instituições acadêmicas}

A Tabela 1.9 apresenta a distribuição dos trabalhos por instituições acadêmicas. A UFRPE é a instituição que mais publicou trabalhos sobre a temática. Cabe ressaltar que os trabalhos dela originários são fruto da parceria entre diversos docentes. Os demais foram realizados por instituições diversas, não se verificando concentração de trabalhos em nenhuma delas.

Tabela 1.9 - Classificação dos trabalhos de acordo com a instituição de origem.

\begin{tabular}{lcl}
\hline $\mathbf{N}^{\circ}$ & Sigla & Instituição \\
\hline 1 & UFRPE & Universidade Federal Rural de Pernambuco \\
2 & UFRGS & Universidade Federal do Rio Grande do Sul \\
3 & UFRPE & Universidade Federal Rural de Pernambuco \\
4 & USP/IQSC & Universidade de São Paulo, Instituto de Química São Carlos \\
5 & UFRPE & Universidade Federal Rural de Pernambuco \\
6 & IOC/UFF & Universidade Federal Fluminense - Instituto Oswaldo Cruz \\
7 & UNIDESC & Centro Universitário de Desenvolvimento do Centro Oeste \\
\hline
\end{tabular}

Assim, percebe-se que a região nordeste, onde se localiza a UFRPE, é a maior contribuinte quando nos referimos à aprendizagem cooperativa. Os demais trabalhos foram realizados em regiões diferentes no Brasil. A única região onde não encontramos trabalhos sobre o tema é a região norte.

Cabe ainda destacar a existência de um trabalho na revista Educação e Pesquisa, referente ao ano de 2005, entretanto sua realização ocorreu na Colômbia, na Universidad Pedagogica Nacional. Logo, não o consideramos representativo para a análise da produção no contexto nacional. 


\section{A produção e sua distribuição de acordo com a área de pesquisa e com os níveis de escolaridade}

Conforme ilustra a Tabela 1.10, na produção dos trabalhos destacam-se os destinados à área de Química e Ciências, sendo quatro trabalhos apresentados na primeira e dois na segunda.

Tabela 1.10 - Classificação dos trabalhos de acordo com a área de enfoque e nível de escolaridade.

\begin{tabular}{ccc}
$\mathbf{N}^{\mathbf{0}}$ & Área & Nível de escolaridade \\
\hline 1 & Química & Fundamental e Superior \\
2 & Ciências & Fundamental \\
3 & Química & Médio \\
4 & Química & Médio \\
5 & Ciências & Fundamental \\
6 & Biologia & Médio e Superior \\
7 & Química & Médio \\
\hline
\end{tabular}

Diferentemente das tendências observadas nos trabalhos internacionais, que privilegiavam o ensino superior, no Brasil, a maioria dos trabalhos é voltada para o ensino médio e fundamental, indicando uma carência com relação à realização de pesquisas no ensino superior. A adoção de estratégias cooperativas neste nível de ensino é relevante, pois, conforme indicam as pesquisas internacionais, pode contribuir para o aperfeiçoamento de diversas habilidades exigidas pelo mercado de trabalho.

\section{A produção e sua distribuição de acordo com o foco temático}

Conforme ilustra a Tabela 1.11, os trabalhos 1, 2, 6 e 7 apresentam como foco temático a aprendizagem cooperativa e suas possibilidades. 
Tabela 1.11 - Classificação dos trabalhos de acordo com o foco temático.

\begin{tabular}{ll}
\hline $\mathbf{N}^{\mathbf{0}}$ & Foco temático/Abordagem \\
\hline 1 & Aprendizagem cooperativa e suas possibilidades \\
2 & Aprendizagem cooperativa e suas possibilidades \\
3 & Aprendizagem cooperativa e suas estratégias específicas \\
4 & Aprendizagem cooperativa e suas estratégias específicas \\
5 & Aprendizagem cooperativa e suas estratégias específicas \\
6 & Aprendizagem cooperativa e suas possibilidades \\
7 & Aprendizagem cooperativa e suas possibilidades \\
\hline
\end{tabular}

Os trabalhos 1 e 2 apontam a aprendizagem cooperativa como uma abordagem que melhora os resultados acadêmicos dos alunos e ajuda no desenvolvimento de habilidades sociais. Especificamente como resultado do trabalho 1, os autores destacam a importância da escolha a ser feita pelo professor com relação ao método cooperativo, já que segundo os mesmos, o bom funcionamento da atividade depende fundamentalmente da adequação do método à aula a ser ministrada.

O trabalho 6 compara atividades cooperativas com competitivas, como resultado os autores classificam a atividade cooperativa como válida e esperam que seus resultados contribuam para destacar o seu potencial no ensino de Biologia, tanto em nível médio quanto superior.

No trabalho 7 os autores obtiveram resultados positivos com 0 uso da aprendizagem cooperativa e concluíram que o seu maior beneficio reside no fato de acentuar a motivação nas aulas.

Ainda com o uso da Tabela 1.11, podemos perceber que os trabalhos 3,4 e 5 apresentam como foco temático a aprendizagem cooperativa e suas estratégias específicas. Todos fizeram uso da estratégia do tipo jigsaw, de forma isolada ou combinada com outro tipo de estratégia, como no trabalho 3, o que mostra como esta estratégia começa a se difundir em âmbito nacional. Os três trabalhos destacam como beneficio comum o desenvolvimento de habilidades sociais. 
Diante do exposto percebe-se que os trabalhos encontrados em âmbito nacional estão concentrados nos níveis de escolaridade fundamental e médio, diferentemente do encontrados em âmbito internacional, que estão concentrados no ensino superior. Já com relação à área de ensino, a Química apresenta o maior volume de pesquisas em aprendizagem cooperativa nos dois contextos.

Internacionalmente foi encontrada uma maior diversificação nos focos temáticos, enquanto em âmbito nacional as pesquisas abarcam dois focos principais: aprendizagem cooperativa e suas possibilidades e aprendizagem cooperativa e suas estratégias específicas. É importante lembrar que independente do volume de pesquisas tanto em âmbito nacional quanto internacional os resultados apontam um acentuado uso da estratégia do tipo jigsaw, em parceria ou isolada. $\mathrm{E}$, de forma geral, mostram a aprendizagem cooperativa como uma estratégia capaz de levar os alunos a melhores resultados acadêmicos, trabalhando com motivação e desenvolvendo habilidades sociais. 


\section{OBJETIVOS}

Neste trabalho colocamos em funcionamento uma atividade didática pautada nos preceitos da aprendizagem cooperativa (formato jigsaw) na disciplina "Comunicação e Expressão em Linguagem Científica l", oferecida a alunos ingressantes no Curso de Bacharelado em Química do Instituto de Química de São Carlos, da Universidade de São Paulo (IQSC/USP).

Temos como principal objetivo investigar a dinâmica das interações estabelecidas entre os alunos, dentro dos seus respectivos grupos, a partir da análise das seguintes dimensões: processamento cognitivo, processamento social e funções da fala. Para tanto, nos baseamos no Modelo Analítico proposto por Kumpulainen e Mutanen (1999).

A análise de tais dimensões forneceu subsídios para o desenvolvimento de considerações sobre potencialidades e deficiências da referida atividade na promoção de um ensino tanto de caráter informativo (aprendizagem de conteúdos específicos) quanto formativo (formação mais geral do estudante, estando aí inseridas as questões que envolvem a cidadania). 
Também objetivamos investigar as percepções dos alunos com relação à atividade didática, a partir da aplicação de questionário elaborado com base no trabalho de Eilks (2005). 


\section{REFERENCIAIS TEÓRICOS}

Para que a atividade didática descrita neste trabalho se concretizasse, foi necessária, inicialmente, que determinássemos o método de aprendizagem cooperativa que iríamos adotar dentre aqueles relatados na literatura (COCHITO, 2004; BARBOSA; JÓFILI, 2004, DOYMUS, 2007). Optamos pelo método jigsaw, um dos mais difundidos tanto nacional quanto internacionalmente, conforme indicamos no capítulo Introdução. Tal escolha se deve ao fato da aplicação do método ser apontada como capaz de desenvolver uma postura mais ativa dos alunos, assim como, agregar às atividades ganhos em habilidades interpessoais (JOHNSON; JOHNSON; HOLUBEC, 1999; COCHITO, 2004; BARBOSA; JÓFILI, 2004).

Para investigar a dinâmica das interações estabelecidas entre os alunos, dentro dos seus respectivos grupos, nos baseamos no Modelo Analítico proposto por Kumpulainen e Mutanen (1999).

Os referencias teóricos acima mencionados encontram-se sucintamente descritos a seguir. 


\subsection{Método Cooperativo Jigsaw}

O método jigsaw foi desenvolvido por Aronson (1978). Este pode ser definido como um conjunto de procedimentos específicos que se adéquam ao desenvolvimento de competências cognitivas de nível superior e não se distancia dos princípios fundamentais considerados pelos irmãos Johnson (JOHNSON; JOHNSON; HOLUBEC, 1999). Usado pela primeira vez em 1971, nos Estados Unidos (Austin/ Texas), no período de lutas civis, se mostrou eficiente em amenizar conflitos entre jovens brancos, afro-americanos e hispânicos que se encontravam pela primeira vez juntos em uma sala de aula, fato que gerou conflitos.

Neste método, os alunos trabalham em grupos cooperativos, sendo que o trabalho que cada aluno realiza é essencial para a concretização do trabalho final do grupo e a sua sistemática de funcionamento se assemelha a de um quebra-cabeça, daí a origem do nome jigsaw, que somente está concluído quando todas as peças estão encaixadas. Um esquema da formação dos grupos encontra-se ilustrado na Figura 3.1.

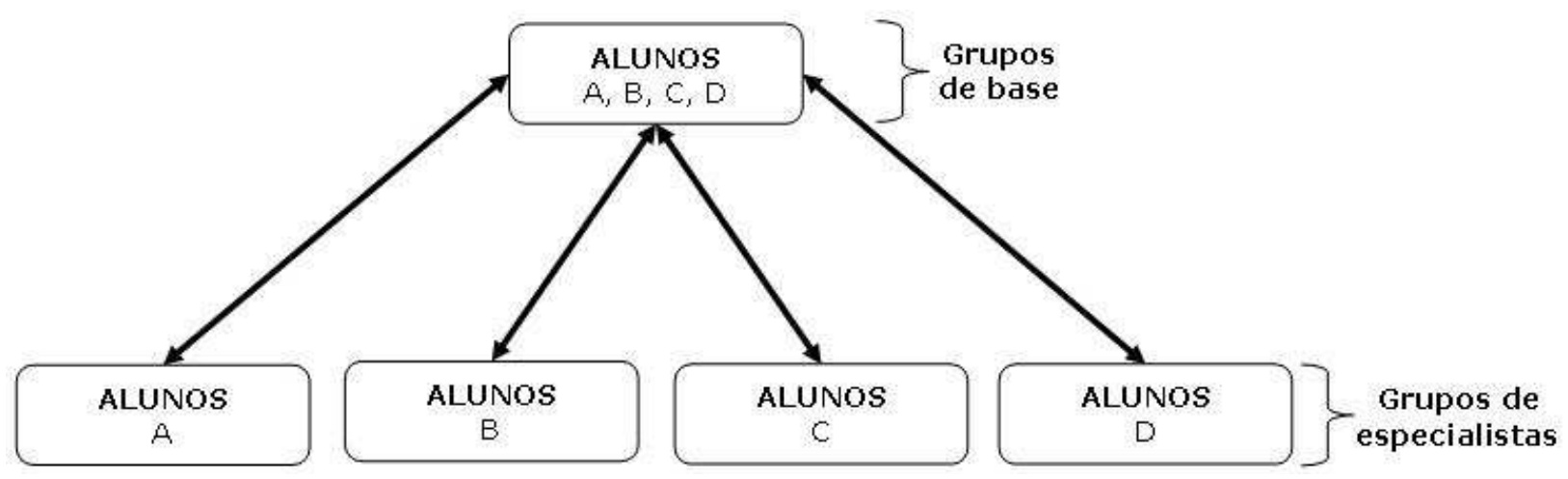

Figura 3.1 - Esquema de formação de pequenos grupos de discussão pelo método jigsaw adaptado de Barbosa e Jófili (2004). Existe apenas um grupo de origem, que é formado por alunos A, B, C e D (grupo de base). Existem quatro subgrupos, que são formados por alunos $A, B, C$ ou $D$ (grupos de especialistas). As setas indicam a movimentação dos alunos nos grupos: todos são provenientes do grupo de origem e a ele retornam, na etapa final da atividade.

$\mathrm{Na}$ primeira fase da atividade os alunos são divididos em grupos de base heterogêneos, com isso evita-se o isolamento e a discriminação na formação dos 
grupos, permitindo que os alunos com mais dificuldade se beneficiem do suporte prestado pelos alunos mais adiantados, ao mesmo tempo as diferenças entre os alunos permitem uma variedade de interações que podem gerar vantagens cognitivas. O material acadêmico é dividido em pequenas partes e cada membro do grupo é designado a estudar apenas uma parte.

$\mathrm{Na}$ segunda fase da atividade, os alunos de grupos de bases diferentes que foram designados a estudar a mesma parte do material didático, estudam e discutem seus materiais juntos, formando grupos de especialistas.

Na terceira fase, depois da discussão nos grupos de especialistas, cada aluno retorna ao seu grupo de base e compartilha o aprendizado adquirido sobre sua parte com os outros membros do seu grupo de base.

Cabe destacar que, no escopo deste trabalho, entendemos o método jigsaw como uma atividade cooperativa formal (JOHNSON; JOHNSON; HOLUBEC, 1999). Assim, conforme discutido no capítulo introdutório desta dissertação, procuramos tornar o trabalho cooperativo funcional e produtivo, garantindo que as seguintes condições permeassem o processo de ensino aprendizagem: interdependência positiva; responsabilidade individual; interação face-a-face; processamento grupal.

A interdependência positiva foi estimulada através do estabelecimento de: - Interdependência positiva de recompensa (os alunos tinham ciência de que se todos os membros do grupo alcançassem média final igual ou superior a oito, todos seriam também recompensados com um ponto extra na média final); • Interdependência positiva de recursos (cada um dos alunos do grupo detinha a posse de apenas parte do material didático necessário para a realização da tarefa solicitada pelo professor); - Interdependência positiva de papéis (nos grupos de base, a cada um dos alunos foi atribuído um dos seguintes papéis: facilitador, porta-voz, mediador/gestor de recursos, 
redator, relator. O facilitador ficou responsável pela efetivação do trabalho e por garantir que todos os membros do grupo tivessem chance de participar e contribuir para a realização da atividade, enquanto o porta-voz ficou responsável por intermediar a relação dos alunos com o docente. O mediador/gestor de recursos ficou responsável por manter as interações entre os membros harmoniosas (precisava atentar para os conflitos, encorajar os comportamentos positivos e não permitir atitudes depreciativas) e por manter acessíveis os materiais necessários para o trabalho, coordenar busca por materiais novos e permitir acesso aos documentos oferecidos pelo docente. $\mathrm{O}$ redator ficou encarregado de redigir as tarefas do grupo de forma clara, enquanto o relator ficou responsável por coordenar as ideias do grupo, tendo que garantir que estas chegassem de forma organizada e coerente ao redator. Sempre atento às falas dos alunos, cabia ao relator negociar com os membros do grupo uma melhor reposta e levá-la ao redator.

A responsabilidade individual foi estimulada através da formação de grupos pequenos (máximo de 5 alunos) e da realização de avaliações individuais sobre o conteúdo da disciplina estudado no jigsaw.

A interação face-a-face entre os alunos ocorreu pelo menos uma vez por semana, no horário formal da disciplina e em ocasiões em que estes foram solicitados a realizar tarefa extraclasse em grupo.

O processamento grupal ocorreu nos últimos quinze minutos de todas as aulas nas quais os alunos trabalharam em seus grupos de base. Este consistiu na seguinte solicitação aos alunos: "Indiquem pelo menos três atitudes/procedimentos do grupo que favoreceram o desenvolvimento do trabalho realizado na aula de hoje" e "Indiquem também algumas atitudes/procedimentos do grupo que podem vir a melhorar o desempenho do grupo nas próximas atividades". 


\subsection{Modelo Analítico de Kumpulainen e Mutanen}

O Modelo Analítico proposto por Kumpulainen e Mutanen (1999) tem como objetivo principal investigar a natureza das atividades sociais dos alunos, em especial as interações verbais realizadas em diferentes situações de aprendizagem. Os alunos do ensino fundamental, participantes das pesquisas relacionadas à elaboração do Modelo, realizaram atividades em pequenos grupos levados a cabo tanto na Finlândia como na Inglaterra (FOURLAS; WRAY, 1990; KUMPULAINEN, 1994, 1996; KUMPULAINEN; MUTANEN, 1998).

Inicialmente o Modelo foi desenvolvido para analisar interações verbais entre os alunos, buscando determinar os papéis destas interações nas atividades de pares e também nas interações com os professores (FOURLAS; WRAY, 1990). Posteriormente o Modelo foi testado, modificado e aplicado por Kumpulainen em um estudo que investigava as atividades sociais ocorridas entre os alunos durante um processo de escrita colaborativa (KUMPULAINEN, 1994; KUMPULAINEN, 1996). Neste contexto o Modelo foi usado com o objetivo de demonstrar as estruturas e a qualidade das interações e, apesar de mostrar potencial de análise, ainda não estava pronto para desvendar as complexidades do processo de aprendizagem social compartilhada.

Pensando nisso, Kumpulainen e Mutanen resolveram buscar um sistema de análise descritiva com uma perspectiva mais holística e multidimensional. O que exigia um Modelo que não fosse focado apenas nas interações verbais e que permitisse entender a construção do conhecimento, valorizando o caráter da atividade, momento a momento, e que tivesse como foco de análise o aluno e o grupo (KUMPULAINEN; MUTANEN, 1999). 
Os interesses acima descritos levaram os autores à formulação do Modelo por nós utilizado, que descreve a dinâmica das interações estabelecidas entre os estudantes, envolvendo cada uma das três dimensões: funções da fala, processamento cognitivo e processamento social.

Primeira dimensão: funções de fala

No que diz respeito à primeira dimensão, são investigadas as estratégias comunicativas adotadas pelos alunos enquanto interagem com os colegas, buscando determinar quais são os significados funcionais das suas falas. Funções de fala podem refletir as expectativas dos alunos frente ao contexto sociocultural da atividade didática proposta pelo professor e permitem interpretar a evolução da situação criada pela atividade, levando a uma análise intra e interpessoal.

A identificação das funções de fala está relacionada com a base do que o orador fala, ou seja, aquilo que sua fala pode implicar, sugerir ou, por vezes, a identificação não tem relação com o significado literal da fala. Sendo assim, elas não são reflexo direto da forma lingüística e sim do contexto em termos de sua retrospectiva e prospectiva, tanto com relação ao conteúdo quanto à forma. Assim, uma expressão é considerada como unidade de intervenção, em outras palavras, uma unidade de mensagem, e a fronteira de cada elocução é linguisticamente marcada pela contextualização de pistas. Uma expressão pode servir a múltiplas funções, logo mais de uma função pode se identificada em cada emissão.

Algumas dessas funções descrevem a natureza da interação com ênfase nas demandas exigidas pela tarefa, enquanto outras enfatizam a perspectiva social ou cognitiva das interações em grupo. O Quadro 3.1 ilustra as funções de falas, 
adaptadas para a nossa análise, a partir do trabalho de Kumpulainen e Mutanen (1999).

Quadro 3.1- Categorização e descrição das funções de falas (adaptação do trabalho de KUMPULAINEN e MUTANEN (1999).

\begin{tabular}{|c|c|}
\hline Categoria & Descrição \\
\hline $\begin{array}{l}\text { Informação } \\
\quad(\text { Inf) }\end{array}$ & $\begin{array}{l}\text { É caracterizada quando ocorre o fornecimento de informação, desde que essa } \\
\text { informação não tenha como objetivo responder uma pergunta ou organizar } \\
\text { ideia ou ação. }\end{array}$ \\
\hline $\begin{array}{l}\text { Avaliação } \\
\text { (Ava) }\end{array}$ & $\begin{array}{l}\text { É caracterizada quando o aluno faz uma avaliação de uma ação ou ideia que } \\
\text { tenha partido do grupo ou de um membro do grupo. }\end{array}$ \\
\hline $\begin{array}{l}\text { Interrogação } \\
\text { (Int) }\end{array}$ & $\begin{array}{l}\text { É caracterizada quando o aluno elabora uma questão ou faz referência a uma } \\
\text { questão feita pela professora ou por outro membro do grupo. }\end{array}$ \\
\hline $\begin{array}{l}\text { Resposta direta } \\
\text { (Res) }\end{array}$ & $\begin{array}{l}\text { É caracterizada quando a fala do aluno busca responder uma pergunta dita } \\
\text { anteriormente de forma simples e objetiva. }\end{array}$ \\
\hline $\begin{array}{l}\text { Resposta critica } \\
\quad(\text { Res-C) }\end{array}$ & $\begin{array}{l}\text { É caracterizada quando a resposta do aluno parte de uma análise mais } \\
\text { aprofundada e elaborada. }\end{array}$ \\
\hline $\begin{array}{l}\text { Complemento de } \\
\text { resposta } \\
\text { (C-Res) }\end{array}$ & $\begin{array}{l}\text { É caracterizada por falas que complementam sentidos de respostas dadas } \\
\text { anteriormente. }\end{array}$ \\
\hline $\begin{array}{l}\text { Organização de ação } \\
\text { (Org-A) }\end{array}$ & $\begin{array}{l}\text { É caracterizada quando a fala do aluno tem o objetivo de organizar o grupo ou } \\
\text { a atividade. }\end{array}$ \\
\hline $\begin{array}{l}\text { Organização de ideia } \\
\text { (Org-I) }\end{array}$ & $\begin{array}{l}\text { E caracterizada quando a fala do aluno tem o objetivo de organizar as ideias } \\
\text { expostas buscando a melhor resposta. }\end{array}$ \\
\hline $\begin{array}{l}\text { De julgamento } \\
\text { (Jul) }\end{array}$ & $\begin{array}{l}\text { É caracterizada quando as falas buscam concordar ou discordar com ações } \\
\text { ou ideias dos demais membros do grupo. }\end{array}$ \\
\hline $\begin{array}{l}\text { Citação crítica } \\
\text { (Cit-C) }\end{array}$ & É caracterizada quando o aluno tenta justificar ou refutar ideias ou ações. \\
\hline $\begin{array}{l}\text { Leitura em voz alta } \\
\qquad \text { (LVA) }\end{array}$ & $\begin{array}{l}\text { É caracterizada pela leitura de um material em voz alta. Seja esse material } \\
\text { produzido pelo leitor, por outro membro do grupo ou por terceiros. }\end{array}$ \\
\hline $\begin{array}{l}\text { Experiencial } \\
\text { (Exp) }\end{array}$ & É caracterizada quando ocorre uma fala relatando experiências pessoais. \\
\hline $\begin{array}{l}\text { Afetiva } \\
\text { (Afe) }\end{array}$ & É caracterizada quando ocorre expressão de sentimentos. \\
\hline $\begin{array}{l}\text { Inclassificável } \\
\text { (Inc) }\end{array}$ & $\begin{array}{l}\text { É caracterizada por funções que não podem ser classificadas nas demais } \\
\text { funções. }\end{array}$ \\
\hline
\end{tabular}

Do Modelo original, composto por quinze categorias, foram suprimidas as seguintes categorias: raciocínio, composição, revisão e ditado. Estas foram suprimidas, pois a estrutura e a complexidade das atividades tornaram sua frequência praticamente nula. Ainda tivemos uma modificação na função argumentação, que passou a ser 
chamada de citação crítica. Isso se fez necessário, uma vez que analisando um grupo de cinco alunos dificilmente ocorreria uma argumentação completa por um só aluno. Entretanto, os argumentos são construídos em processo colaborativo, por partes menores consideradas por nós como citação critica.

Ainda subdividimos as categorias resposta e organização dando origem às categorias: resposta direta, complemento de resposta e resposta critica, organização de ação e organização de ideia. E, por fim, adicionamos as categorias citação critica e inclassificável.

Consideramos adequado dividir as categorias resposta e organização devido à atividade proposta por nós gerar possibilidades de resposta diferenciadas e com objetivos diversos. Quanto à organização, o número de alunos por atividade originou um tipo diferente de fala, direcionada a organizar os pensamentos propostos pelo grupo, diferentemente do trabalho original, no qual os alunos trabalham em duplas. Fato que nos levou a dividir a categoria organização em dois tipos, de ação e de ideias.

Quanto ao acréscimo da categoria inclassificável, podemos inferir que a mesma surgiu da necessidade de categorizar funções que não se enquadrava em nenhuma categoria existente.

Segunda dimensão: processamento cognitivo

No que diz respeito à segunda dimensão, são investigadas as estratégias adotadas pelos alunos, do ponto de vista cognitivo, na resolução da tarefa solicitada pelo professor (Quadro 3.2). 
Quadro 3.2- Categorização e descrição dos processamentos cognitivos.

\begin{tabular}{|l|l|}
\hline \multicolumn{1}{|c|}{ Categorização } & \multicolumn{1}{|c|}{ Descrição } \\
\hline Procedural & Atividade rotineira, que exige apenas a manipulação, \\
organização e execução de tarefas sem análise reflexiva.
\end{tabular}

No Modelo de Kumpulainen e Mutanen (1999) são sugeridas três estratégias cognitivas: na primeira delas, denominada de processamento procedural, os alunos adotam uma sequência de passos conhecidos para alcançar a solução do problema (execuções rotineiras). A segunda, denominada de processamento off-task (fora do contexto da tarefa solicitada), está associada a situações nas quais os alunos não estão engajados na busca de solução para o problema proposto pelo professor. A terceira, denominada processamento interpretativo ou exploratório, está associada a situações nas quais o pensamento crítico é essencial e os alunos se envolvem genuinamente com a atividade, na busca da solução do problema proposto pelo professor. Adaptações não se fizeram necessárias com relação à segunda dimensão do Modelo.

Terceira dimensão: processamento social

No que diz respeito à terceira dimensão, são investigadas as relações sociais estabelecidas entre os alunos no trabalho em grupo. Para tanto, o pesquisador leva em 
consideração o tipo de interação predominante em um intervalo de tempo, sendo considerados aqui os seguintes tipos de interações: colaborativa, tutorial, argumentativa, individualista, dominante, competitiva e modos conflitantes. Este último caracteriza a interação durante um equivoco ou desentendimento entre os pares.

O modo competitivo reflete o desacordo, geralmente em um nível social. 0 modo dominante reflete a distribuição de poder e status em cada grupo. $O$ modo individualista e o dominante são contrários à interação do modo colaborativo. O modo argumentativo e o modo de tutorial podem ser caracterizados como submodelos do modo colaborativo. O modo argumentativo implica em interação construtiva entre os alunos que discutem diferentes visões em um âmbito racional, apresentando julgamentos e justificava. Isso muitas vezes leva a uma compreensão compartilhada da situação. O modo tutorial implica em assistência dada por um aluno a outro com o objetivo de compreender o assunto em pauta, também inclui interações nas quais os participantes tentam alcançar um entendimento mútuo da situação, ideias são negociadas em conjunto e o discurso é coerente.

As seguintes adaptações se fizeram necessárias com relação à terceira dimensão do Modelo com o intuito de adequá-la a uma atividade de grupo com número superior a dois componentes. Alem das diferenças no número de alunos, em nossa atividade, diferentemente da original, ocorria à interação entre os alunos e o docente o que nos fez modificar a categoria tutorial para que esta se adequasse á nova realidade.

Desta forma, consideramos que as interações podem ser basicamente de quatro tipos: colaborativo (caracterizado pela igual participação dos membros do grupo na realização das tarefas) e tutorial (caracterizado pelo auxílio prestado por um estudante ou professor a outro membro na realização da tarefa). O processamento social do tipo individualista é definido como confuso e pode ser caracterizado pelo trabalho individual 
do estudante, sem compartilhamento das dúvidas e conclusões com os demais membros do grupo, ou pelo domínio de um dos membros na realização da tarefa. O processamento social do tipo competitivo é definido como modo de conflito e pode ser caracterizado pela ocorrência de conflitos sociais ou acadêmicos não solucionados. $\mathrm{O}$ processamento social do tipo nulo é caracterizado pela falta de compreensão entre os alunos ou da própria tarefa.

Cabe destacar que para análise das três dimensões não existem regras que limitem as categorias usadas, pois, conforme indicado pelos autores (KUMPULAINEN; MUTANEN, 1999), o Modelo deve ser usado considerando-se as peculiaridades de cada atividade de grupo. 


\section{PERCURSO METODOLÓGICO}

A pesquisa em questão pode ser considerada do tipo qualitativa, isso porque trabalhamos principalmente com a interpretação da fala e ações dos alunos, durante aulas de Química. Além disso, nossa pesquisa tem como cenário o ambiente natural de aula como fonte direta de dados e o pesquisador é tido como o principal instrumento; os dados coletados são predominantemente descritivos; o processo é predominante em relação ao produto e a análise dos dados tende a seguir um processo indutivo, Esses aspectos caracterizam nossa pesquisa como qualitativa de acordo com Ludke e Andre (1986).

Nossa pesquisa contou com os seguintes métodos de coleta: observação, gravações em áudio e questionários. Para a análise, se mostrou necessário a transcrição das gravações das falas dos alunos, registradas no decorrer das aulas da referida disciplina durante o semestre letivo. Todo o processo de transcrição foi realizado com cuidado para manter a fidelidade das falas correspondentes. Optamos ainda pela correção gramatical de algumas citações (CARVALHO, 2006). 


\subsection{Contexto de Aplicação da Proposta}

A proposta de ensino em questão foi aplicada no primeiro semestre de 2008 na disciplina "Comunicação e Expressão em Linguagem Científica I", oferecida aos alunos do primeiro ano do Curso de Bacharelado em Química do Instituto de Química de São Carlos, disciplina de caráter obrigatório, ministrada em duas horas semanais. O docente contou com o auxilio de dois alunos da pós-graduação participantes do Programa de Aperfeiçoamento de Ensino (PAE) da Universidade de São Paulo (USP), que o auxiliaram na elaboração e aplicação das atividades realizadas e na construção de materiais didáticos.

A disciplina (2 créditos, teórica) visa à discussão das diversas formas como a ciência é divulgada, a apresentação aos estudantes de alguns tipos de documentos científicos e suas características peculiares, assim como de fontes de informação em ciência e tecnologia. Atividades que buscam a promoção de discussões sobre a importância da comunicação científica para o profissional da área de Química, com ênfase no papel da linguagem escrita, são também realizadas na disciplina (OLIVEIRA; QUEIROZ, 2007), que é tradicionalmente ministrada a partir da realização de aulas expositivas, de trabalhos em grupo e de aulas práticas na biblioteca.

No primeiro dia de aula a disciplina contava com 51 alunos matriculados e ao final do semestre com 62 , os 11 alunos adicionais se juntaram à turma devido às chamadas subsequentes à primeira chamada do vestibular. Os 51 alunos inicialmente engajados na disciplina foram distribuídos em grupos cooperativos heterogêneos, uma vez que responderam a um questionário de caracterização que subsidiou a sua distribuição nos grupos. Os demais alunos não participaram da etapa de formação dos 
grupos heterogêneos, porém participaram das atividades cooperativas e também avaliaram a proposta de ensino ao final da sua aplicação.

Os alunos foram divididos em 12 grupos, 10 grupos heterogêneos de 5 membros e 2 grupos de 6 membros não heterogêneos. Selecionamos aleatoriamente 5 grupos heterogêneos, acompanhamos suas atividades e registramos seus diálogos em áudio. Nessa perspectiva, apenas 25 alunos foram tomados como sujeitos na investigação das interações estabelecidas nas atividades realizadas no modelo cooperativo jigsaw.

\subsection{Aplicação da Proposta}

\section{Etapa 1: Formação dos grupos heterogêneos}

Conforme mencionamos anteriormente, os grupos heterogêneos foram formados com base na aplicação de um questionário de caracterização preenchido pelos alunos no primeiro dia de aula (Anexo B). Este, adaptado do trabalho de Ferreira e Queiroz (2010), era constituído por 30 questões, divididas em quatro blocos.

Para a formação dos grupos heterogêneos lançamos mão dos seguintes critérios: formação estudantil do aluno, habilidade em escrita, interesse e motivação pela leitura. Para a definição do primeiro critério fizemos uso da sétima questão do Bloco 1, que indagava "Você teve alguma outra experiência durante ou após esse período (outro curso de graduação, curso técnico-profissionalizante, etc.). Se sim, especifique." Consideramos as respostas fornecidas à questão, pois entendemos que os alunos que apresentam formação do tipo técnica ou advinda de outras universidades teriam mais facilidade para discorrer sobre a temática em pauta na disciplina. 
O segundo critério foi definido ao analisarmos os textos produzidos pelos alunos na resolução do questionário, dentre eles selecionamos os que apresentavam uma boa escrita, tendo como base para considerar uma boa escrita o trabalho de Vidal (1998), que a define como sendo clara, legível, rápida, elegante e com liberdade de execução. Também usamos como parâmetro para o segundo critério os questionamentos encontrados nos Blocos 2 e 3: "Quantos livros você lê, em média, por ano?"; "Verifique a lista de revistas de divulgação científica citadas a seguir e assinale aquelas que você já teve a oportunidade de ler."; "Na maioria das vezes, com que finalidade você lê?"; "Acha importante a leitura? Por quê?"; "Quando vai estudar como é a sua relação com a leitura?"; "Quando lê com outro propósito o faz da mesma maneira?”. Considerando as respostas fornecidas às questões, definimos os alunos que apresentavam maior interesse e motivação pela leitura.

Tendo em mãos os resultados dos questionários separamos os alunos em três grupos com o intuito de, a partir dessa triagem inicial, redistribuí-los em 10 grupos de característica heterogênea: o grupo A, composto pelos alunos que atenderam aos dois critérios; o grupo B, composto pelos alunos que atenderam apenas um dos critérios; o grupo C, foi formado com os alunos que não atenderam a nenhum dos dois critérios. Assim, dos 51 alunos que responderam ao questionário, 18 formaram o grupo $\mathrm{A}, 24$ formaram o grupo B, e 9 formaram o grupo $\mathrm{C}$.

Primeiramente distribuímos os alunos do grupo A nos 10 grupos heterogêneos, Dessa forma, cada grupo contou com pelo menos um aluno com curso superior (completo ou incompleto) ou técnico. Esta medida nos pareceu relevante ao considerarmos que tais alunos provavelmente tiveram maior contato com documentos do tipo que seria estudado na disciplina e poderiam direcionar as atividades auxiliando seus companheiros de forma mais efetiva. 
Em seguida, distribuímos os alunos do grupo B de forma que cada grupo um dos 10 grupos heterogêneos contou com a presença de pelo menos dois alunos vindos do referido grupo. Tendo em vista que a maioria dos alunos atendeu ao segundo critério, apresentando interesse e motivação pela leitura, consideramos que os mesmos poderiam ajudar os demais alunos na elaboração e resolução das tarefas.

Por ultimo, distribuímos os alunos do grupo C, de forma que dos 10 grupos heterogêneos, 9 contaram com a presença de um aluno do referido grupo.

\section{Etapa 2: Aulas iniciais (expositivas dialogadas)}

Ainda no primeiro dia de aula o docente responsável pela disciplina fez uma apresentação geral sobre a mesma, informando o conteúdo a ser ministrado e seus principais objetivos. Após a apresentação, os alunos entraram em contato com a proposta do nosso projeto e se dispuseram a participar como sujeitos da pesquisa assinando o Termo de Consentimento e Informação (Anexo C).

No segundo dia de aula os alunos conheceram as distribuições dos grupos de base e assistiram a uma aula sobre aprendizagem cooperativa, com foco especial no funcionamento do método jigsaw. A apresentação teve como objetivo dar conhecimento aos alunos sobre a metodologia e suas peculiaridades e explicar como esta seria aplicada na disciplina (interdependência de papéis, interdependência de recompensa, processamento grupal etc), assim como sanar possíveis dúvidas existentes por parte dos alunos. Em seguida o docente indicou uma referência completa de cada um dos seguintes tipos de documento que deveriam ser trazidos pelos membros dos grupos de base para a aula seguinte (Anexo D): artigo científico original de pesquisa, artigo de revisão, artigo de divulgação científica, artigo de educação em Química, tese ou dissertação. 


\section{Etapa 3: Aula pautada no trabalho dos grupos de base (parte I)}

No terceiro dia de aula os alunos se reuniram nos chamados grupos de base, cada aluno com seu respectivo documento. Assim, cada grupo constituído por cinco alunos detinha um tipo de cada um dos documentos solicitados pelo docente, como apresentado na Figura 4.1. Para realização da atividade foi entregue aos alunos um questionário relativo aos documentos que o grupo tinha em mãos (Anexo E). O objetivo do questionário foi buscar uma resposta coletiva dos alunos sobre as características dos diferentes documentos.

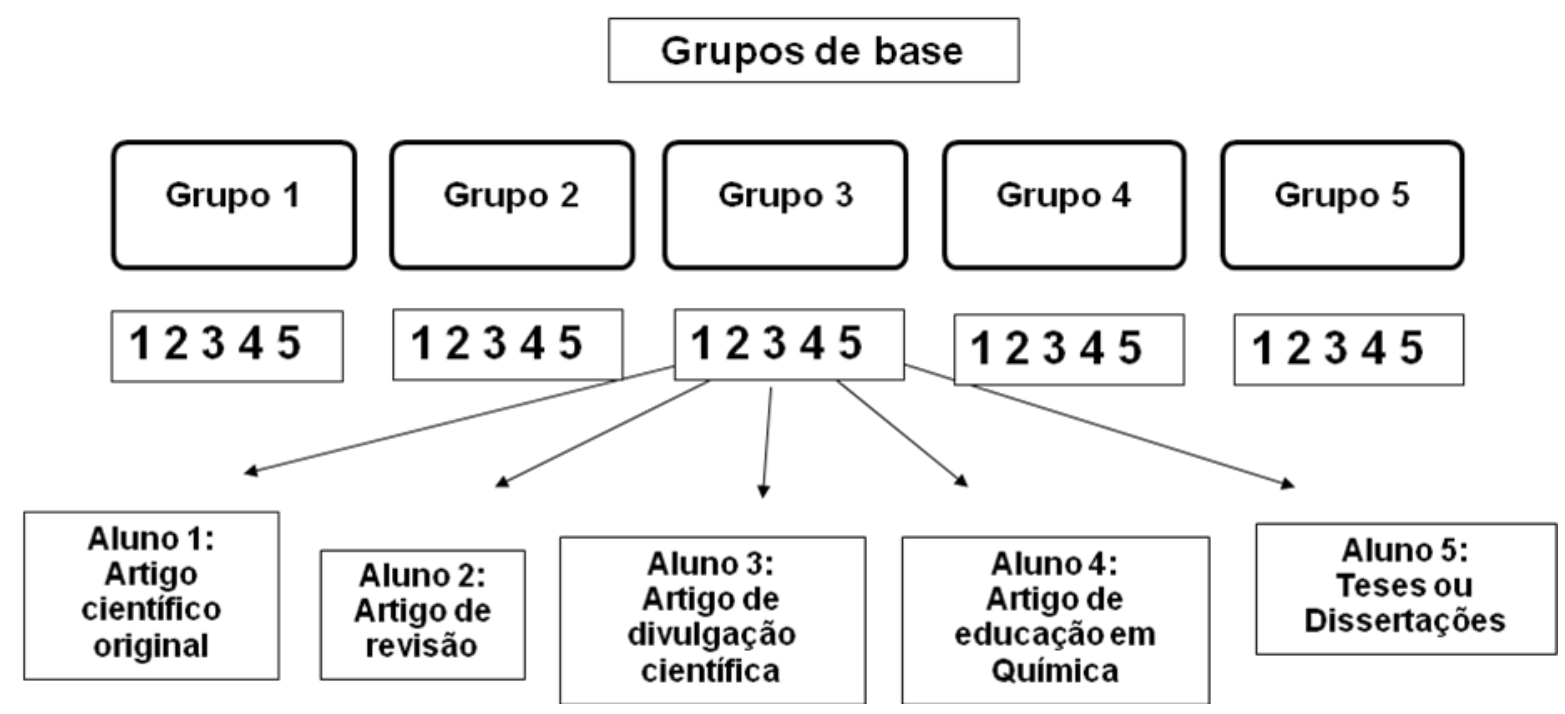

Figura 4.1 - Apresentação dos grupos de base, cada grupo composto por cinco alunos, cada um com um tipo de documento.

Cabe lembrar que dentro do grupo de base cada aluno era responsável por exercer uma das seguintes funções determinada pelo docente: mediador, relator, redator, porta voz e facilitador/gestor de recursos. Ao final da atividade os alunos realizaram o processamento grupal, respondendo á questão apresentada, no capítulo Referenciais Teóricos desta dissertação.

Ao final da aula os alunos foram incumbidos de realizar uma atividade extraclasse (Anexo F), contendo questões relacionadas às características estruturais dos seus respectivos documentos. 


\section{Etapa 4: Aula pautada no trabalho dos grupos de especialistas}

No quarto dia de aula os alunos de grupos de base diferentes, mas que foram designados a estudar o mesmo documento, discutiram sobre os seus documentos específicos em um novo grupo (denominado grupo de especialistas). Assim, por exemplo, os alunos especialistas em artigos de divulgação científica investigaram características comuns a textos desse tipo, porém provenientes de revistas distintas, conforme ilustra a Figura 4.2.

\section{Grupos de especialistas}

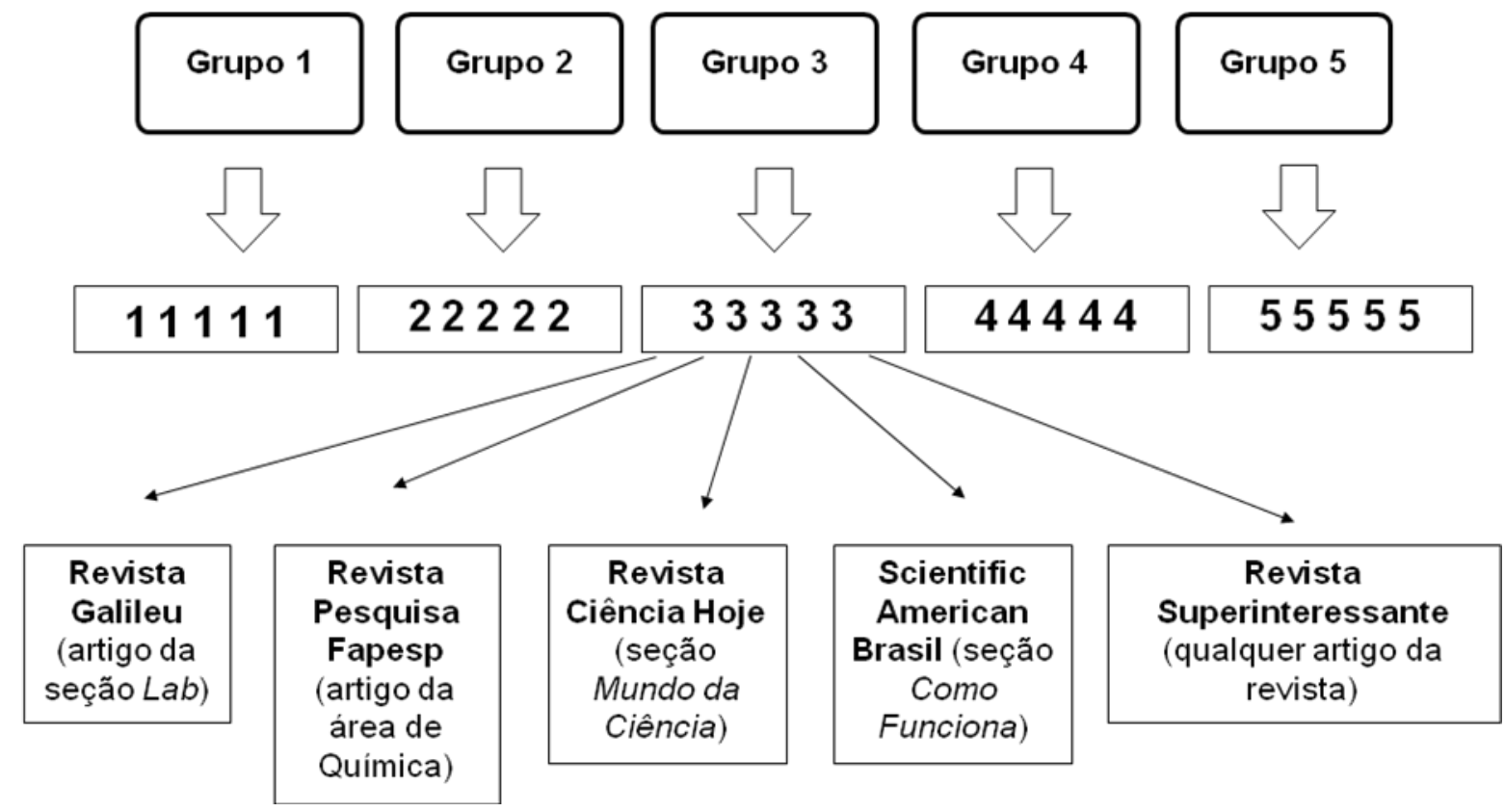

Figura 4.2 - Constituição do grupo de especialistas em artigos de divulgação científica.

$\mathrm{Na}$ ocasião o docente entregou uma nova atividade (Anexo G), a partir da qual os alunos tiveram um contato mais aprofundado sobre as características do seu documento especifico. Cada aluno apresentou as respostas dadas para atividade extraclasse (Anexo F), e após uma discussão o grupo chegou a um consenso sobre a melhor resposta e, por fim, desenvolveu um texto sobre o documento estudado. 


\section{Etapa 5: Aula pautada no trabalho dos grupos de base (parte II)}

No quinto dia de aula os alunos participantes dos grupos de especialistas retornaram aos seus grupos de base e compartilharam com os demais alunos o conhecimento adquirido no grupo de especialista. Além do conhecimento adquirido, cada aluno tinha em mãos um texto organizado sobre seu documento e, a partir dessa nova perspectiva, os alunos aprimoraram as questões produzidas na atividade inicial solicitada aos grupos de base (Anexo E), agora munidos de uma visão privilegiada sobre a totalidade dos documentos. Assim, no final da realização do jigsaw, todos os membros dos grupos entraram em contato com todo o conteúdo.

Ao final dessa atividade os alunos realizaram novamente o processamento grupal.

\section{Etapa 6: Avaliação do conteúdo e da atividade didática}

Uma vez concluídas as atividades do jigsaw, os alunos participaram de uma avaliação final individual sobre o conteúdo estudado e responderam a um questionário, elaborado com base no trabalho de Eilks (2005), tendo em vista o conhecimento das suas impressões sobre a atividade didática. Afirmações relacionadas à potencialidade do método jigsaw no ensino da disciplina e à sua contribuição para o desenvolvimento de habilidades formativas e informativas dos alunos encontram-se nele presentes. A versão do questionário, adaptada aos objetivos e ao contexto da nossa investigação, encontra-se no Anexo H. 


\section{RESULTADOS E DISCUSSÃO}

Com o objetivo de investigar as interações ocorridas durante as atividades realizadas nos grupos de base e nos grupos de especialistas, procuramos classificar as transcrições das falas de todos os participantes dos grupos de acordo com as três dimensões propostas por Kumpulainen e Mutanen (1999). Deste modo, construímos mapas analíticos, nos moldes ilustrados no Quadro 5.1. Os mapas analíticos para todos os grupos são apresentados no CD-ROM, em anexo.

No Quadro 5.1 apresentamos um trecho do mapa analítico da primeira atividade do grupo de base, realizada pelo Grupo 1. No mapa analítico temos duas unidades de análise, a primeira, chamada de unidade de mensagem, é referente a uma exposição verbal que possa representar uma mensagem; a segunda unidade é marcada por períodos de tempo determinados de 2 minutos. No mapa, cada unidade de mensagem é numerada e classificada na primeira dimensão (função de fala) e na segunda dimensão (processamento cognitivo). A segunda unidade de análise é classificada na terceira dimensão (processamento social). Os fragmentos proferidos pelo docente e pelos alunos de pós-graduação que o auxiliaram foram transcritos, entretanto, não 
foram classificados. Assim, o Quadro 5.1 exemplifica como o mapa foi construído para cada um dos grupos, permitindo a organização e a análise dos dados.

Quadro 5.1 - Trechos do mapa analítico das interações ocorridas no Grupo 1.

\begin{tabular}{|c|c|c|c|c|}
\hline $\begin{array}{l}\text { Unidade de } \\
\text { Mensagem }\end{array}$ & $\begin{array}{l}\text { Função } \\
\text { de fala }\end{array}$ & Fragmentos da transcrição & $\begin{array}{l}\text { Processo } \\
\text { Cognitivo }\end{array}$ & Agente \\
\hline 145 & Int & É a questão 1, já está feita? & PCR & A2 \\
\hline 146 & Int & Vocês viram isso? & PCE & A3 \\
\hline 147 & $\operatorname{lnf}$ & No Caribe eles tiram. & PCE & A3 \\
\hline 148 & Ava & Osmose reversa.É da hora isso! & PCE & A2 \\
\hline 149 & $\operatorname{lnf}$ & $\begin{array}{l}\text { No Caribe eles tiram muita água. No Caribe não, no } \\
\text { Iraque, Oriente Médio. }\end{array}$ & PCE & A3 \\
\hline 150 & Cit-C & Também lá é tudo deserto, tem que tirar muita água. & PCE & A2 \\
\hline 151 & Inf & Vinte bilhões de litros de água. & PCE & A3 \\
\hline 152 & $\operatorname{lnf}$ & Por dia, caramba! & PCE & A2 \\
\hline 153 & Cit-C & $\begin{array}{l}\text { É bom tirar mesmo porque em vintes anos a água vai } \\
\text { entrar em crise igual a do petróleo de } 1973 \text {. }\end{array}$ & PCE & A2 \\
\hline 154 & Ava & É muita coisa. & PCE & A3 \\
\hline 155 & Cit-C & $\begin{array}{l}\text { É muita pensando em número, porque se pensar em } \\
\text { população... }\end{array}$ & PCE & A2 \\
\hline 156 & Int & O seu (artigo) é do que? & PCR & A4 \\
\hline 157 & Res & Divulgação. & PCR & A3 \\
\hline 158 & Int & O seu é sobre cristalização, água doce que vem do mar? & PCR & A2 \\
\hline 159 & Res & Isso. & PCR & A3 \\
\hline 160 & Ava & O meu é sobre água também. Legal. & PCR & A2 \\
\hline 161 & Inf & $\begin{array}{l}\text { Olha o meu aqui. Especialistas acreditam que em vinte } \\
\text { anos teremos uma crise semelhante a do petróleo de } 73 \text {. }\end{array}$ & PCR & A2 \\
\hline 162 & Cit-C & $\begin{array}{l}\text { Vinte anos, sendo que a revista é de } 2001 \text {, mas a } \\
\text { probabilidade era de vinte até trinta anos. De vinte a vinte } \\
\text { cinco anos. }\end{array}$ & PCE & A2 \\
\hline 163 & Inc & Também a água de hoje em dia. & PCR & $\mathrm{A} 2$ \\
\hline 164 & Int & Tem o volume, alguma coisa? & PCR & A4 \\
\hline 165 & Res & Embaixo da revista, normalmente. & PCR & $\mathrm{A} 2$ \\
\hline 166 & Res & Não tem volume. & PCR & A4 \\
\hline
\end{tabular}




\begin{tabular}{|c|c|l|c|c|}
\hline 167 & Int & Não tem volume? & PCR & A3 \\
\hline 168 & Int & Não tem? & PCR & A5 \\
\hline 169 & Org-A & Deixa eu anotar o nome da revista, então. & PCR & A4 \\
\hline Tempo & 2min & Processamento social: Colaborativo & & \\
\hline
\end{tabular}

Int = interrogação; Res= resposta; Inf= informação; Org-A= organização de ação; $A v a=$ avaliação; Cit-C= citação crítica; Inc= Inclassificável; $\mathrm{PCR}=$ processamento cognitivo rotineiro; $\mathrm{PCE}=$ processamento cognitivo exploratório; $A X=$ Aluno $X$, sendo $X$ de 1 a 5.

\subsection{Primeira Dimensão: Funções de Fala}

\subsubsection{Distribuição das Funções de Fala por Aluno nas Atividades Realizadas}

Como ponto de partida para a análise das interações, buscamos definir a distribuição das funções de falas por aluno nas três atividades de grupo realizadas. Escolhemos para esta análise, aleatoriamente, atividades realizadas por um dos grupos de base e por um dos grupos de especialistas. Assim, foram definidas as freqüências com que cada aluno utilizou cada uma das funções de falas. A seleção dos grupos representativos nos pareceu plausível já que a distribuição das funções de fala dos diferentes grupos não se mostrou diferenciada significativamente, em uma análise prévia. Dessa forma, a exposição de todos os resultados não traria ganhos consideráveis à pesquisa.

A Figura 5.1 ilustra a frequência de uso das funções de fala, na qual o eixo y indica as diferentes funções de fala e o eixo $x$ indica a freqüência com que cada aluno usou cada uma das funções. Cada aluno é representado por uma cor especifica indicada na legenda do gráfico. 


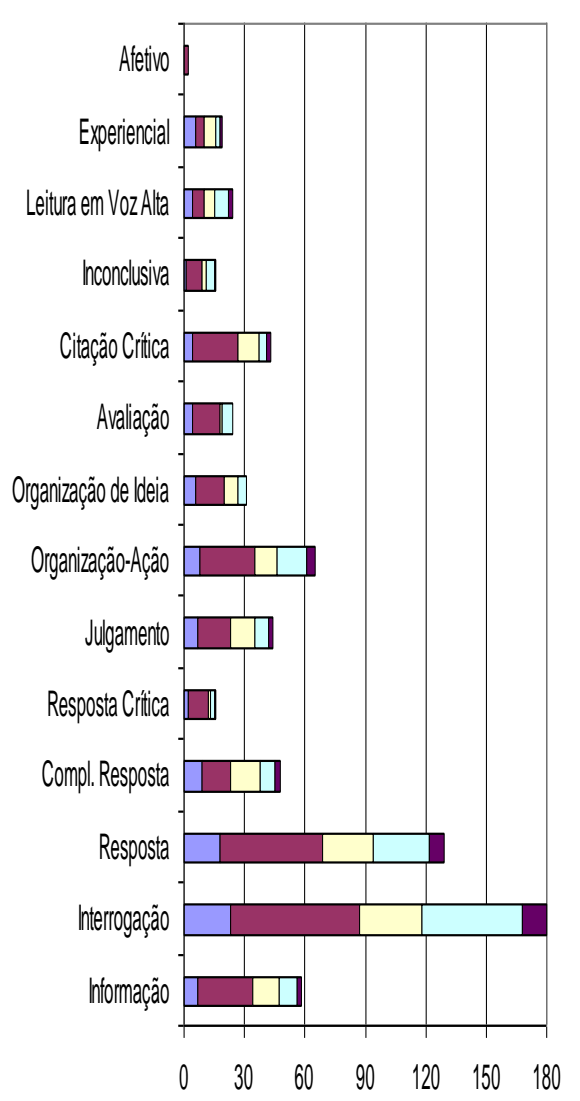

(a)

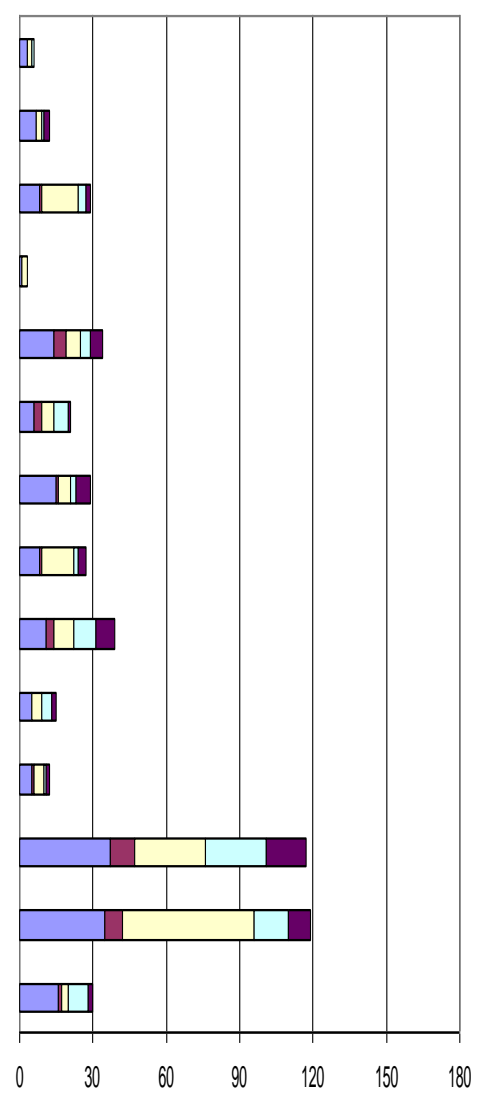

(b)

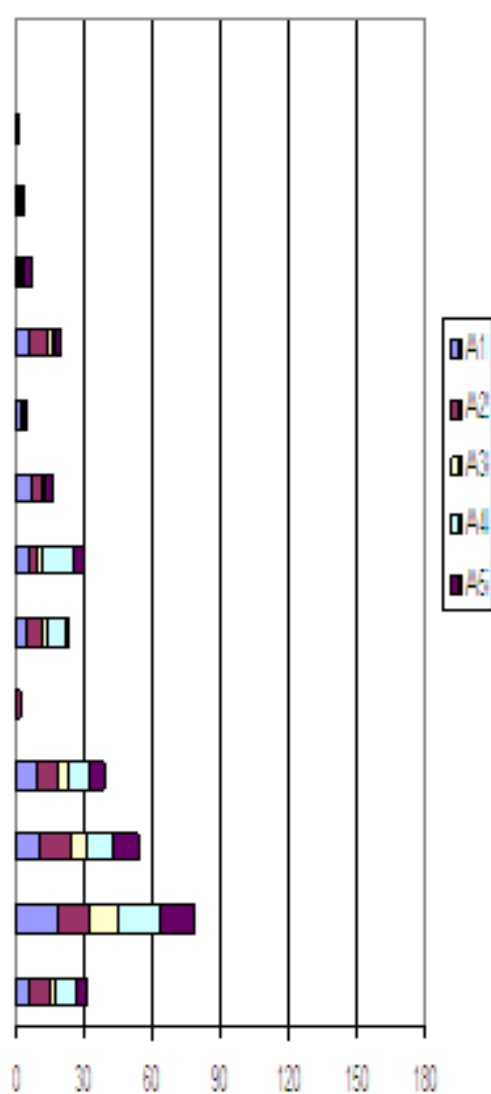

(c)

Figura 5.1 - Freqüência de uso das funções de fala por alunos na primeira (a) e segunda atividade dos grupos de base (c) e na atividade dos grupos de especialistas (b).

Podemos perceber que praticamente todas as funções de falas foram usadas por todos os alunos nas três atividades, apenas na segunda atividade dos grupos de base não constatamos o uso da função do tipo afetivo. O uso diversificado das funções de fala pelos alunos nos leva a duas inferências: primeiro, que a atividade apresentou uma gama de possibilidades cognitivas, fazendo com que os alunos contribuíssem de formas diversas e amplas no seu decorrer; segundo, podemos inferir que os alunos trabalharam de forma consideravelmente igualitária para a realização da atividade. Este fato se mostra mais positivo ao acompanharmos a distribuição no decorrer da segunda atividade nos grupos de base, na qual os alunos se encontraram em uma 
condição mais igualitária, cada um sendo responsável por parte fundamental do trabalho, que só poderia ser dominada por ele.

Os dados indicam que os alunos trabalharam de forma cooperativa, sugerindo que, em principio, o objetivo central da atividade didática foi alcançado. Resta saber como a atividade ocorreu e a sua contribuição para formação dos alunos. Cabe destacar que este resultado também nos permite partir de uma análise de grupo, não mais como uma atividade sem organização, no qual um trabalha e os outros acompanham, e sim como uma atividade marcada pelo equilíbrio e pela unidade. Este equilíbrio ocorreu, provavelmente, graças ao fato da atividade seguir os preceitos básicos do cooperativismo descritos pelos irmãos Johnson: interdependência positiva; responsabilidade individual; interação face-a-face; processamento grupal (JOHNSON; JOHNSON; HOLUBEC, 1999).

\subsubsection{Distribuição das Funções de Fala nos Grupos de Base: Primeira e Segunda Atividade}

Com o intuito de otimizarmos nossa análise com relação às funções de fala distribuímos as mesmas em três blocos. O primeiro é composto pelas funções de fala do tipo interrogação (Int), resposta (Res), complemento de resposta (C-Res), informação (Inf) e leitura em voz alta (LVA). Estas funções refletem as interações ocorridas entre os interlocutores principalmente na perspectiva de busca de caminhos para a resolução da atividade proposta pelo professor.

O Quadro 5.2 apresenta trechos do mapa analítico da primeira atividade do Grupo 1, nos quais as funções de fala do primeiro bloco se fazem presentes. 
Quadro 5.2- Trechos do mapa analítico das interações ocorridas no Grupo 1, exemplificando as funções de fala pertencentes ao primeiro bloco.

\begin{tabular}{|c|c|c|c|c|}
\hline $\begin{array}{l}\text { Unidade } \\
\text { de } \\
\text { Mensagem }\end{array}$ & $\begin{array}{l}\text { Função } \\
\text { de fala }\end{array}$ & Fragmento 1 & $\begin{array}{l}\text { Processo } \\
\text { Cognitivo }\end{array}$ & Agente \\
\hline 185 & Int & A tese de doutorado a gente não tem familiaridade. Tem? & PCR & A5 \\
\hline 186 & Res & Não tem como. & PCR & A2 \\
\hline 187 & C-Res & A parte que é mais séria. & PCR & A5 \\
\hline 188 & Inf & $\begin{array}{l}\text { O meu é a da água. Todo mundo tem base, ainda mais } \\
\text { por causa da escassez que está vindo aí. }\end{array}$ & PCR & A2 \\
\hline $\begin{array}{c}\text { Unidade } \\
\text { de } \\
\text { Mensagem }\end{array}$ & $\begin{array}{l}\text { Função } \\
\text { de fala }\end{array}$ & Fragmento 2 & $\begin{array}{l}\text { Processo } \\
\text { Cognitivo }\end{array}$ & Agente \\
\hline 253 & Int & O artigo é eclético, dirigido a... É isso? & PCR & A4 \\
\hline 254 & $\begin{array}{l}\text { LVA- } \\
\text { Res }\end{array}$ & $\begin{array}{l}\text { Aqui está escrito assim: Artigo que relata resultado } \\
\text { original de pesquisa. }\end{array}$ & PCR & A1 \\
\hline
\end{tabular}

O segundo bloco é composto pelas funções de fala do tipo organização de ação (Org-A), experiencial (Exp), julgamento (Jul), avaliação (Ava) e afetiva (Afe). Essas funções, entre as demais funções, são as que melhor refletem o grau de interação social ocorrida entre os interlocutores.

O Quadro 5.3 apresenta trechos do mapa analítico da primeira e segunda atividade do Grupo 2, nos quais as funções de fala do segundo bloco se fazem presentes.

Quadro 5.3- Trechos do mapa analítico das interações ocorridas no Grupo 2, exemplificando as funções de fala pertencentes ao segundo bloco.

\begin{tabular}{|c|c|l|c|c|}
\hline $\begin{array}{c}\text { Unidade } \\
\text { de } \\
\text { Mensagem }\end{array}$ & $\begin{array}{c}\text { Função } \\
\text { de fala }\end{array}$ & \multicolumn{1}{|c|}{ Fragmento 1 } & $\begin{array}{c}\text { Processo } \\
\text { Cognitivo }\end{array}$ & Agente \\
\hline 65 & Org-A & E você passa para o final. & PCR & A2 \\
\hline 66 & Jul & Tudo bem, então. & PCR & A5 \\
\hline 67 & Afe & Tomara que você entenda a letra dele. & PCR & A4 \\
\hline
\end{tabular}




\begin{tabular}{|c|c|c|c|c|}
\hline 68 & Org-A & Então vai. & PCR & A4 \\
\hline $\begin{array}{l}\text { Unidade } \\
\text { de } \\
\text { Mensagem }\end{array}$ & $\begin{array}{l}\text { Função } \\
\text { de fala }\end{array}$ & Fragmento 2 & $\begin{array}{l}\text { Processo } \\
\text { Cognitivo }\end{array}$ & Agente \\
\hline 295 & Exp & $\begin{array}{l}\text { Eu tenho uma capacidade impressionante para essas } \\
\text { coisas. }\end{array}$ & PCR & A2 \\
\hline 296 & & Eu já errei meu nome no vestibular. & PCO & A4 \\
\hline $\begin{array}{l}\text { Unidade } \\
\text { de } \\
\text { Mensagem }\end{array}$ & $\begin{array}{l}\text { Função } \\
\text { de fala }\end{array}$ & Fragmento 3 & $\begin{array}{l}\text { Processo } \\
\text { Cognitivo }\end{array}$ & Agente \\
\hline 607 & Ava & $\begin{array}{l}\text { Mais simples, menos cansativo para quem vai ler } \\
\text { também. }\end{array}$ & PCR & A4 \\
\hline 608 & Jul & Eu acho. & PCR & A2 \\
\hline 609 & Ava & Está bom demais. & PCR & A3 \\
\hline
\end{tabular}

O terceiro bloco é composto pelas funções de fala do tipo resposta crítica (ResC), citação crítica (Cit-C) e organização de ideia (Org-I). Estas funções refletem as interações dos interlocutores do ponto de vista intrapessoal, já que exigem um alto grau de elaboração pessoal, são relacionadas diretamente ao desenvolvimento cognitivo dos alunos.

O Quadro 5.4 apresenta trechos do mapa analítico da primeira atividade do Grupo 1, nos quais as funções de fala do terceiro bloco se fazem presentes.

Quadro 5.4- Trechos do mapa analítico das interações ocorridas no Grupo 1, exemplificando as funções de fala pertencentes ao terceiro bloco.

\begin{tabular}{|c|c|c|c|c|}
\hline $\begin{array}{c}\text { Unidade } \\
\text { de } \\
\text { Mensagem }\end{array}$ & $\begin{array}{c}\text { Função } \\
\text { de fala }\end{array}$ & Fragmento 1 & $\begin{array}{c}\text { Processo } \\
\text { Cognitivo }\end{array}$ & Agente \\
\hline 260 & Res-C & $\begin{array}{l}\text { Ah, ele apresenta o resultado da pesquisa, ele coloca o } \\
\text { objetivo do projeto, aí ele apresenta o resultado, tem } \\
\text { gráfico, tem tabela. Os resultados todos. }\end{array}$ & PCE & $\mathrm{A} 1$ \\
\hline $\begin{array}{c}\text { Unidade } \\
\text { de } \\
\text { Mensagem }\end{array}$ & $\begin{array}{c}\text { Função } \\
\text { de fala }\end{array}$ & Fragmento 2 & $\begin{array}{c}\text { Processo } \\
\text { Cognitivo }\end{array}$ & Agente \\
\hline 277 & Res-C & $\begin{array}{l}\text { O vocabulário do artigo, por exemplo, é bem mais } \\
\text { elaborado. }\end{array}$ & PCR & A3 \\
\hline
\end{tabular}




\begin{tabular}{|c|c|l|c|c|}
\hline $\begin{array}{c}\text { Unidade } \\
\text { de } \\
\text { Mensagem }\end{array}$ & $\begin{array}{c}\text { Função } \\
\text { de fala }\end{array}$ & Fragmento 3 & $\begin{array}{c}\text { Processo } \\
\text { Cognitivo }\end{array}$ & Agente \\
\hline 303 & Org-I & Coloca: a Tese é direcionada para um espaço científico. & PCR & A4 \\
\hline 304 & Cit-C & Não precisa escrever muito não. & PCE & A3 \\
\hline 609 & Ava & Está bom demais. & PCR & A3 \\
\hline
\end{tabular}

No Quadro 5.5 apresentamos a frequência expressa em porcentagem com que cada função de fala foi utilizada pelos cinco grupos de base, na primeira e segunda atividade respectivamente.

Quadro 5.5- Distribuição das funções de fala para cada grupo de base participante da primeira e segunda atividade.

\begin{tabular}{|l|c|c|c|c|c|c|c|c|c|c|}
\hline & \multicolumn{2}{|c|}{ Grupo 1 } & \multicolumn{2}{c|}{ Grupo 2 } & \multicolumn{2}{c|}{ Grupo 3 } & \multicolumn{2}{c|}{ Grupo 4 } & \multicolumn{2}{c|}{ Grupo 5 } \\
\hline & AT1 & AT2 & AT1 & AT2 & AT1 & AT2 & AT1 & AT2 & AT1 & AT2 \\
\hline & $\mathbf{( \% )}$ & $\mathbf{( \% )}$ & $\mathbf{( \% )}$ & $\mathbf{( \% )}$ & $\mathbf{( \% )}$ & $\mathbf{( \% )}$ & $\mathbf{( \% )}$ & $\mathbf{( \% )}$ & $\mathbf{( \% )}$ & $\mathbf{( \% )}$ \\
\hline Int & 26,0 & 26,2 & 20,2 & 28,5 & 29,3 & 25,3 & 24,5 & 24 & 29,8 & 27,5 \\
\hline Res & 17,8 & 16,8 & 19,0 & 19,0 & 22,3 & 17,5 & 19,1 & 19,8 & 20,5 & 21,5 \\
\hline C-Res & 6,9 & 12,3 & 13,5 & 10,1 & 7,5 & 13,7 & 7,2 & 8,5 & 4,3 & 8,3 \\
\hline Inf & 7,6 & 8,4 & 11,6 & 7,1 & 12,9 & 6,5 & 13,6 & 14 & 11,7 & 7,8 \\
\hline LVA & 2,7 & 1,3 & 1,7 & 1,8 & 3,1 & 0,3 & 1,9 & 0 & 1,0 & 2,0 \\
\hline Org-A & 9,9 & 10,4 & 8,9 & 6,8 & 6,3 & 7,2 & 7,0 & 10,5 & 8,8 & 10,7 \\
\hline Exp & 2,4 & 0,3 & 1,2 & 3,0 & 2,1 & 0 & 0,9 & 1,7 & 1,0 & 0 \\
\hline Jul & 6,2 & 6,5 & 8,4 & 4,7 & 4,0 & 6,5 & 5,6 & 7,5 & 6,6 & 5,4 \\
\hline Ava & 3,8 & 2,3 & 4,7 & 5,0 & 3,3 & 4,8 & 6,9 & 2,8 & 4,5 & 1,0 \\
\hline Afe & 0,1 & 0,3 & 0,4 & 0 & 0,3 & 0 & 0,8 & 2,5 & 1,6 & 0 \\
\hline Cit-C & 7,6 & 7,4 & 4,9 & 5,6 & 3,7 & 8,2 & 4,1 & 2,5 & 4,7 & 5,4 \\
\hline Org-I & 4,2 & 4,9 & 2,3 & 3,6 & 1,9 & 4,8 & 3,2 & 3,5 & 2,6 & 6,4 \\
\hline Res-C & 2,3 & 0,6 & 1,2 & 2,1 & 2,1 & 1,4 & 1,5 & 1,0 & 0,7 & 2,0 \\
\hline Inc & 2,4 & 2,3 & 2,0 & 2,7 & 1,1 & 3,8 & 3,7 & 1,7 & 2,2 & 2,0 \\
\hline Total & $\mathbf{1 0 0} \%$ & $\mathbf{1 0 0} \%$ & $\mathbf{1 0 0} \%$ & $\mathbf{1 0 0} \%$ & $\mathbf{1 0 0} \%$ & $\mathbf{1 0 0} \%$ & $\mathbf{1 0 0 \%}$ & $\mathbf{1 0 0 \%}$ & $\mathbf{1 0 0 \%}$ & $\mathbf{1 0 0 \%}$ \\
\hline
\end{tabular}

Int = interrogação; Res= resposta; C-Res= complemento de resposta; Inf= informação; LVA= leitura em voz alta; Org-A= organização de ação; $E x p=$ experencial; Jul= julgamento; $A v a=$ avaliação; $A f e=$ afetiva; Cit-C= citação crítica; Org-I organização de ideia; Res-C= resposta crítica e Inclassificável; $A T 1$ e AT2= primeira e segunda atividade dos grupos de base, respectivamente.

Com relação às funções de fala que compõem o primeiro bloco (interrogação, resposta, complemento de resposta, informação e leitura em voz alta), nas duas atividades a somatória destas funções representou aproximadamente $66 \%$ do total das 
funções em praticamente todos os grupos de base. Este resultado indica que os alunos se mantiveram focados na resolução da atividade. O bom desenvolvimento da atividade por parte dos alunos mostra que o docente responsável conseguiu adaptar a estratégia cooperativa ao conteúdo da disciplina em questão, o que confirma os resultados encontrados pelos autores Seetharaman e Musier-Forsyth (2003), que indicam o alto grau de adaptabilidade da estratégia jigsaw.

Outro fator relevante a se considerar é que o número de funções de respostas, em média 19,3\%, somado ao de funções de complemento de resposta, em média $9,2 \%$, é muito próximo e em alguns grupos superior ao número de interrogações, em média $26 \%$, mostrando que muitas perguntas formuladas no grupo encontraram mais do que uma resposta. Este resultado é indicativo do comprometimento, busca pela melhor resposta e responsabilidade individual dos alunos no desenvolvimento da atividade, sugerindo que estes tiveram a oportunidade de aperfeiçoar suas habilidades acadêmicas, com relação ao conteúdo ministrado na disciplina. Resultados similares, relacionados à melhoria do desempenho acadêmico dos alunos foram reportados pelos seguintes autores na aplicação de estratégias cooperativas: Felder (1996), Dougherty (1997), Towns, Kreke e Fields (2000), Lyon e Lagowski (2008).

Com relação às funções de fala que compõem o segundo bloco, (organização de ação, experiencial, julgamento, avaliação e afetiva), nas duas atividades o uso médio foi em torno de 20,6\%, indicando a sua constância relevante. Dentre elas, as mais usadas, em média, pelos alunos foram, respectivamente, organização de ação $(8,7 \%)$, julgamento $(6,1 \%)$ e avaliação $(3,9 \%)$. O uso da função afetiva foi muito pequeno em todos os grupos $(0,6 \%)$, provavelmente devido ao fato dos alunos serem ingressantes no semestre de aplicação da proposta e não terem ainda estreitado seus laços de amizade. O uso destas funções indica o grau de interação estabelecido entre 
os alunos durante a realização das atividades, assim tais funções em número considerável sugerem um alto grau de interação e organização da atividade, mostrando que os alunos não se omitiram frente ao trabalho dos seus colegas de grupo, avaliando e questionando as respostas dadas pelos seus pares, fato relevante, pois demonstra que os alunos tiveram oportunidade de trabalhar suas habilidades sociais e participaram de forma ativa, sem deixar de lado o seu ponto de visa em detrimento dos outros alunos do grupo. Estes resultados reforçam aqueles encontrados na literatura, que apontam a aprendizagem cooperativa como uma atividade capaz de promover o desenvolvimento de habilidades sociais (FELDER, 1996; TOWNS; KREKE; FIELDS, 2000).

Com relação às funções de fala que compõem o terceiro bloco, (resposta crítica, citação crítica e organização de ideia), nas duas atividades o seu uso médio se deu em torno de 10,6\%, valor esperado já que estas funções exigem um grau elevado de elaboração por parte dos alunos, como apontado por Kumpulainen e Mutanen (1999). Mais importante do que o resultado em valor absoluto de uso destas funções é o fato de os alunos, mesmo tendo trabalhado com foco no cumprimento da tarefa, como sugere o elevado uso das funções do primeiro bloco (66\%), não terem deixado de lado a qualidade das respostas. De fato, por vezes, o grau de organização e as funções direcionadas à finalização da atividade os levaram à vivência de momentos argumentativos, pautados na especulação de resultados e na formulação de hipótese. Assim acreditamos que este resultado reflete a boa qualidade da atividade. Os trabalhos de García e Tuñón, (2004) e Mllls et al. (1999) apresentam resultados semelhantes ao supracitado.

Os resultados expostos no Quadro 5.5, ainda nos permitem tecer comentários comparativos entre a primeira e segunda atividade. Podemos perceber um aumento no 
uso da maioria das funções do terceiro bloco de análise, da primeira para a segunda atividade, ocorrendo uma evolução com relação à atividade realizada no primeiro grupo de base. Podemos especular que esse fato se deu devido à estrutura da atividade e à postura dos alunos que apresentaram um maior controle sobre o desenvolvimento da mesma. Em parte, essa melhoria talvez possa ser creditada à realização do processamento grupal na primeira atividade, que permitiu que os alunos refletissem sobre a melhor forma de trabalhar nos grupos de base. A importância do processamento grupal já foi anteriormente destaca por autores como Johnson, Johnson e Holubec (1999).

\subsubsection{Distribuição das Funções de Fala nos Grupos de Especialistas}

A mesma sistemática de análise adotada para a tessitura de considerações sobre as funções de fala nos grupos de base foi seguida para os grupos de especialistas. Assim, o Quadro 5.6 ilustra a freqüência expressa em porcentagem com que cada função de fala foi utilizada pelos cinco grupos de especialistas.

Quadro 5.6- Distribuição das funções de fala para cada grupo de especialistas.

\begin{tabular}{|l|c|c|c|c|c|}
\hline & Educação (\%) & Divulgação (\%) & Revisão (\%) & Originais (\%) & Tese (\%) \\
\hline Int & 27,6 & 24,7 & 27,7 & 23,5 & 10,9 \\
\hline Res & 25,4 & 25,4 & 22,9 & 19,2 & 19,8 \\
\hline C-Res & 8,8 & 2,3 & 7,6 & 7,3 & 8,9 \\
\hline Inf & 5,0 & 6,8 & 8,4 & 9,2 & 7,4 \\
\hline LVA & 5,9 & 6,1 & 3,2 & 2,6 & 5,9 \\
\hline Org-A & 6,4 & 5,5 & 5,6 & 5,2 & 12,9 \\
\hline Exp & 0,7 & 2,1 & 0,4 & 1,9 & 1,0 \\
\hline Jul & 5,7 & 6,8 & 4,8 & 8,4 & 6,9 \\
\hline Ava & 4,6 & 3,6 & 2,4 & 3,8 & 6,7 \\
\hline Afe & 0,0 & 1,1 & 0,0 & 0,5 & 1,2 \\
\hline C-Cri & 3,9 & 6,6 & 6,4 & 6,8 & 6,7 \\
\hline Org-I & 3,5 & 5,5 & 2,8 & 7,0 & 5,4 \\
\hline Res-C & 2,0 & 2,8 & 6,8 & 2,8 & 5,2 \\
\hline Inc & 0,4 & 0,6 & 0,8 & 1,7 & 1,0 \\
\hline \multicolumn{1}{|c|}{ Total } & $\mathbf{1 0 0 \%}$ & $\mathbf{1 0 0} \%$ & $\mathbf{1 0 0} \%$ & $\mathbf{1 0 0 \%}$ & $\mathbf{1 0 0 \%}$ \\
\hline
\end{tabular}


A análise dos dados expostos no Quadro 5.6 evidencia que os cinco grupos fizeram uso das funções de fala de forma muito similar com algumas diferenças pontuais. Todos os grupos usaram de forma intensa às funções de fala que compõem o primeiro bloco (interrogação, resposta, complemento de resposta, informação e leitura em voz alta), com valor médio próximo ao apresentado nos grupos de base de $66 \%$. Mais importante ainda, como nos grupos de base, o número de funções de falas do tipo resposta e complemento de resposta somados, apresentaram valor absoluto maior do que as funções do tipo interrogação, indicando que mais do que um aluno apresentou resposta para uma mesma indagação, o que contribui para o aperfeiçoamento das respostas.

Percebemos diferenças no uso da função leitura em voz alta, que comparativamente com os grupos de base teve seu uso intensificado, isto, provavelmente, devido ao fato de todos os alunos terem lido as respostas que trouxeram elaboradas, como exigido na atividade extraclasse (ANEXO F). Com relação ao uso das funções do segundo bloco, (organização de ação, experiencial, julgamento, avaliação e afetiva), cabe destacar que a atividade de especialistas colocou frente a frente alunos com conhecimento prévio equivalente sobre o conteúdo estudado, assim o uso efetivo de funções do tipo organização de ação, julgamento e avaliação reflete a intenção dos alunos de coordenar o trabalho do grupo, contribuindo com sugestões concordantes ou discordantes, e avaliando o trabalho dos seus pares. Mais uma vez reforça-se o desenvolvimento de habilidades interpessoais e responsabilidade individual.

Destacamos ainda que o uso das funções de fala organização de ideia, citação critica e resposta critica foi significativo, fato que demonstra que houve alguns 
momentos de conflitos cognitivos durante esta atividade, indicando que os alunos buscaram uma resposta bem elaborada.

Esta busca pela melhor resposta é também reforçada pelo uso das funções do tipo julgamento e avaliação que indicam uma forte interação entre os alunos do grupo de especialistas, que passaram por vários episódios especulativos.

\subsection{Segunda Dimensão: Processamento Cognitivo}

\subsubsection{Processamento Cognitivo nos Grupos de Base: Primeira e Segunda}

\section{Atividade}

Conforme mencionamos anteriormente, identificamos os seguintes processamentos cognitivos: rotineiro, off-task e exploratório. O primeiro diz respeito a períodos em que os alunos direcionam seus esforços à realização de atividades que exigem apenas a manipulação, organização e execução, sem análise reflexiva. 0 segundo se relaciona a períodos nos quais os alunos direcionam sua interação para atividades não vinculadas à tarefa solicitada pelo professor. O terceiro diz respeito a períodos em que ao alunos direcionam seus esforços à realização de atividades críticas e exploratórias, que incluem planejamento, levantamento de hipóteses, avaliação e experimentação.

Trechos dos mapas analíticos desenvolvidos para os grupos de base na realização da primeira atividade contendo os processamentos cognitivos existentes são ilustrados no Quadro 5.7. 
Quadro 5.7- Trechos do mapa analítico das interações ocorridas no Grupo 3 na primeira atividade dos grupos de base, exemplificando os tipos de processamento cognitivos.

\begin{tabular}{|c|c|c|c|c|}
\hline $\begin{array}{l}\text { Unidade de } \\
\text { Mensagem }\end{array}$ & $\begin{array}{l}\text { Função } \\
\text { de fala }\end{array}$ & Fragmento 1 & $\begin{array}{l}\text { Processo } \\
\text { Cognitivo }\end{array}$ & Agente \\
\hline 248 & Int & Posso dar uma olhada? & PCR & A2 \\
\hline 249 & Inf & Não tem, agora tem que ver como funciona. & PCR & A4 \\
\hline \multirow[t]{2}{*}{250} & Org-A & $\begin{array}{l}\text { Depois você conversa com ela, aqui vamos fazer essas } \\
\text { anotações, que é o grupo de base e tem aquele outro } \\
\text { grupo específico. }\end{array}$ & PCR & A1 \\
\hline & & Fragmento 2 & & \\
\hline 523 & & O livro parece que foi ela que escreveu. & PCO & A5 \\
\hline 524 & & Foi. & PCO & A3 \\
\hline \multirow[t]{2}{*}{525} & & Isso daqui é de prática de laboratório? & PCO & A5 \\
\hline & & Fragmento 3 & & \\
\hline 382 & Org-I & $\begin{array}{l}\text { Aí a gente justificou a da Stephannie, que é de educação } \\
\text { (artigo) e tem uma linguagem mais simples e mais } \\
\text { acessível e a sua que também está em uma revista mais } \\
\text { específica, com uma linguagem mais fácil. }\end{array}$ & PCE & A3 \\
\hline 423 & Cit-C & $\begin{array}{l}\text { E pode colocar que todos se assemelham, tem um ponto } \\
\text { comum em todos, que eles falam da ciência. }\end{array}$ & PCE & A3 \\
\hline
\end{tabular}


A Figura 5.2 apresenta a porcentagem de uso dos três tipos de processamentos cognitivos pelos grupos de base na primeira e segunda atividade.

(a)

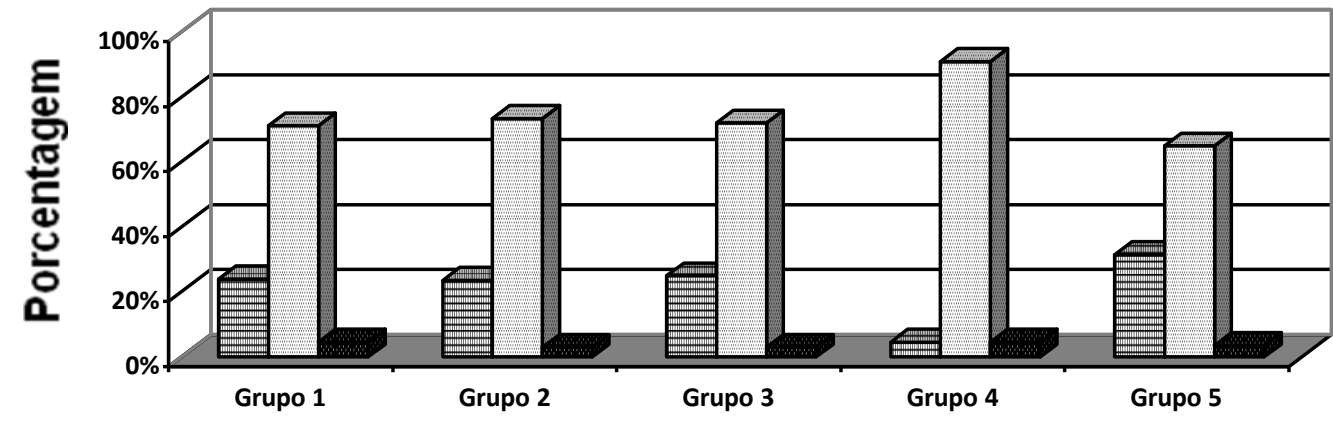

(b)

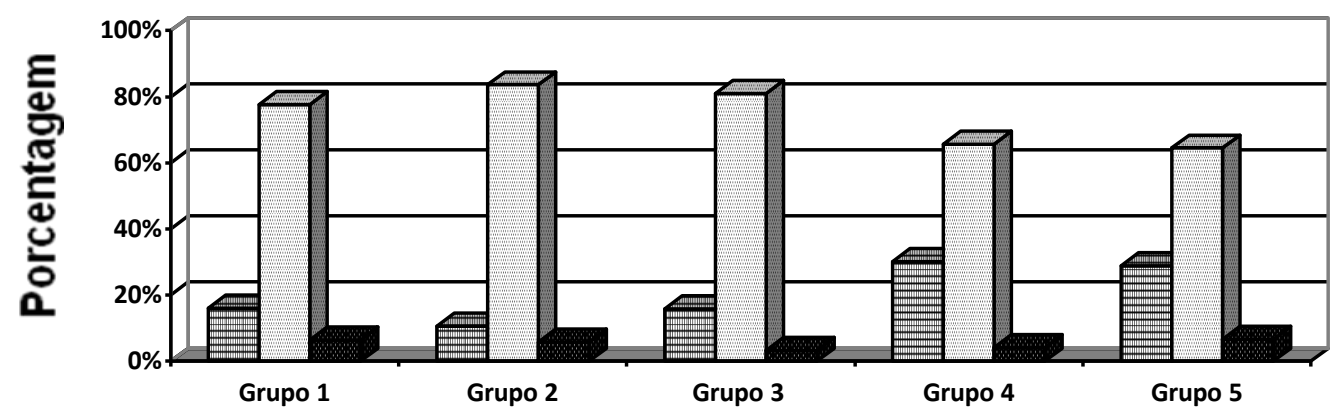

Figura 5.2 - Porcentagem de uso dos processamentos cognitivos durante a resolução da primeira (a) e segunda (b) atividade dos grupos de base.

A partir da análise da Figura 5.2 percebemos que os grupos de base usaram os três processamentos cognitivos seguindo a mesma tendência nas duas atividades, sendo o processamento cognitivo rotineiro (PCR) usado prioritariamente, seguido do processamento cognitivo off-task $(\mathrm{PCO})$ e por último o processamento cognitivo exploratório (PCE). Essa ordem já era esperada, considerando os trabalhos reportados na literatura e as características que os mesmos atribuem à aprendizagem cooperativa. O percentual verificado para o processamento cognitivo rotineiro indica que os alunos participaram da atividade de forma comprometida, focando sua realização de forma eficiente; em relação ao processamento cognitivo off-task, o percentual verificado indica que os alunos desenvolveram a atividade de forma descontraída, intercalando a execução das tarefas com momentos sem tensões, necessários em uma atividade que 
se espera motivadora; por último, o percentual verificado para o processamento cognitivo exploratório indica que a atividade proporcionou momentos de desenvolvimento cognitivo, privilegiando o conhecimento exploratório, que gera além de uma melhor qualidade de resposta, uma aprendizagem mais ativa.

O uso do processamento cognitivo rotineiro foi superior a $60 \%$ em todos os grupos, tendo valor máximo de $91 \%$ no Grupo 4, na primeira atividade. O seu uso prioritário demonstra 0 interesse dos alunos em realizar a atividade. Este direcionamento para o término da atividade está diretamente relacionado com o grande uso de funções de falas do primeiro bloco, citados anteriormente, e fortalecem a ideia de que durante a atividade os alunos tiveram a oportunidade de desenvolver e melhorar suas habilidades, com relação ao conteúdo acadêmico.

A importância do processamento do tipo rotineiro é clara, embora o seu uso majoritário possa representar os bons resultados, não garante um trabalho amistoso e descontraído. Sendo assim, não podemos deixar de dar importância para o processamento do tipo off-task.

O uso do processamento cognitivo off-task se mostrou variável entre os grupos nas duas atividades, como tendência pode-se perceber que a maioria dos grupos diminuiu o seu grau de descontração da primeira para a segunda atividade do grupo de base. Este fato está relacionado, provavelmente, com caráter finalizador da segunda atividade proposta. Para ilustrar como um número considerável de processamento cognitivo off-task pode indicar uma atividade motivadora e descontraída, são descritos a seguir trechos de falas de alunos do Grupo 5: "Está tão bom isso daqui, vocês são tão tranquilos, será que vai ser assim?", "Tomara", "Está tão tranqüilo de fazer.", "Tomara"; "Tomara que continue assim, conversar de boa, comunicativo." "Tomara". 
Estes trechos, ditos por 4 dos 5 membros participantes do grupo, demonstram a importância da realização de atividades de forma descontraída, amplamente discutida em trabalhos reportados na literatura (THURSTON et al., 2010; HELLER et al., 1992).

Cabe destacar que o número excessivo de processamento cognitivo off-task pode prejudicar a resolução das tarefas e qualidade das respostas, quando isso ocorre temos um exemplo de interdependência negativa, de forma que um ou mais alunos não conseguem desenvolver o trabalho em sintonia com os demais, prejudicando o trabalho em grupo.

O uso do processamento cognitivo exploratório ocorreu de forma muito parecida em todos os grupos, na primeira atividade, com valor médio de 4,0\%. Na segunda atividade os valores variaram de $4,0 \%$ a $6,6 \%$. O aumento no uso deste tipo de processamento evidencia uma evolução no decorrer da atividade, sugerindo que os

alunos realizaram um trabalho mais ativo e buscaram respostas mais elaboradas. É relevante perceber que os grupos, em sua maioria, apresentaram evolução, sinalizando a qualidade da atividade proposta. Cabe ressaltar ainda que na segunda atividade os alunos se encontravam em um nível muito mais pareado de conhecimento relativo tendo cada um que contribuir com parte essencial do trabalho, o que tornou a sua participação mais importante e efetiva para a realização da atividade, justificando pelo menos parcialmente, a melhora observada.

\subsubsection{Processamento Cognitivo nos Grupos de Especialistas}

Os processamentos cognitivos usados pelos grupos de especialistas seguiram, de uma maneira geral, tendências semelhantes aquela adotada nos grupos de base na primeira e segunda atividade, conforme ilustra a Figura 5.3, que apresenta a porcentagem de uso dos três tipos de processamentos cognitivos. 


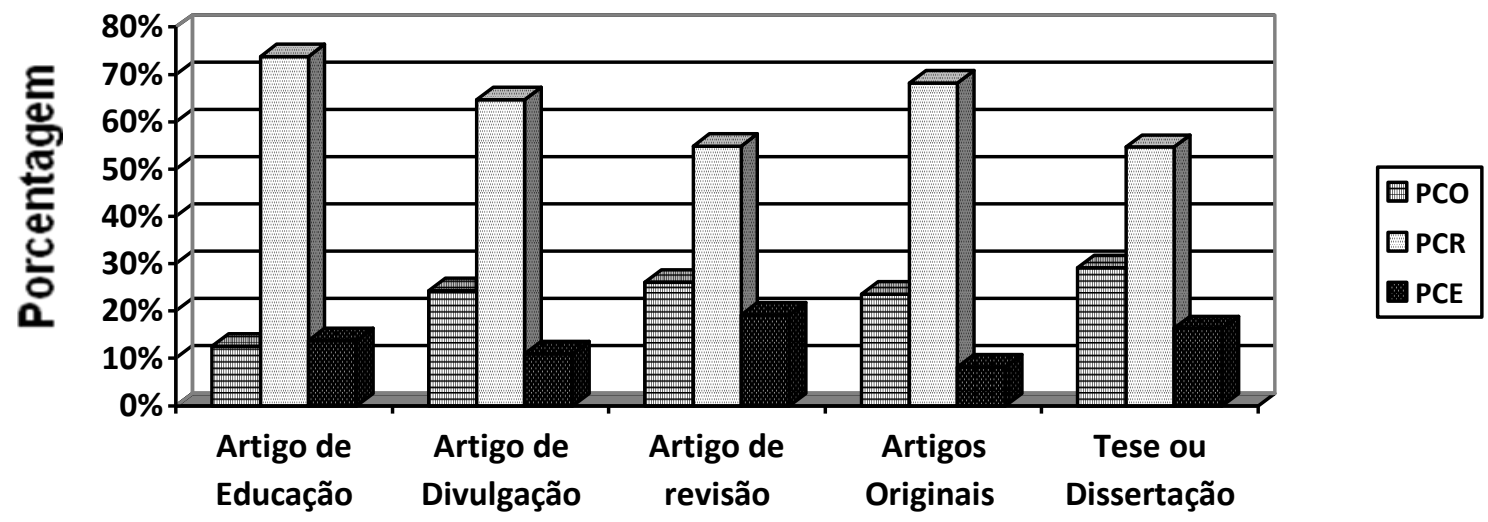

Figura 5.3 - Porcentagem de uso dos processamentos cognitivos durante a resolução da atividade dos grupos de especialistas.

O uso de processamento cognitivo rotineiro, mais uma vez foi prioritário em todos os grupos, o que mostra que os alunos se mantiveram focados na resolução da atividade. Ou seja, mesmo não estando em seus grupos de base, os alunos não deixaram que o trabalho no grupo de especialistas tomasse um rumo de desorganização ou de conflito.

Com relação ao uso do processamento cognitivo off-task, este se manteve em nível semelhante praticamente em todos os grupos (em torno de $25 \%$ ), assim como havia sido observado em grande parte dos grupos de base. Aparentemente, o uso de processamentos off-task nesse percentual não prejudicou a realização das tarefas.

Com relação ao uso do processamento cognitivo exploratório, sua frequência se mostrou bem diferente quando comparado à observada nos grupos de base. De fato, ao observarmos a Figura 5.3 percebemos que o uso do processamento cognitivo exploratório teve seu mínimo de $8,2 \%$ no grupo especialista em artigo original e máximo de 19,1\% no grupo especialista em artigo de revisão. Assim, o grupo de especialista responsável pelo uso mínimo de processamentos exploratórios usou, em valores percentuais, o dobro do valor dos grupos de base, que o fizeram uso em torno de $4 \%$. 
Provavelmente esta diferença está diretamente relacionada com a estrutura da atividade, o grupo de especialista tem exatamente o propósito de fazer com que os alunos se encontrem em situação de igualdade para discutir uma melhor resposta. $\mathrm{O}$ uso mais freqüente do processamento do tipo exploratório sugere que o objetivo da atividade foi contemplado, de forma que os alunos tiveram a chance de enfrentar conflitos cognitivos, que geram um esforço para compreender e resolver problemas.

\subsection{Terceira Dimensão: Processamento Social}

\subsubsection{Processamento Social nos Grupos de Base: Primeira e Segunda}

\section{Atividade}

Com o uso dos mapas analíticos construídos para cada grupo de base identificamos as interações dominantes ocorridas no decorrer da resolução da primeira e segunda atividade. Como resultado deste processo originou-se o gráfico ilustrado na Figura 5.4, no qual são expostos os quatro tipos de interações sociais considerados, neste trabalho, assim como os valores em porcentagem referentes à frequência de uso dos diferentes processamentos sociais pelos grupos de base, na primeira e segunda atividade, respectivamente. 


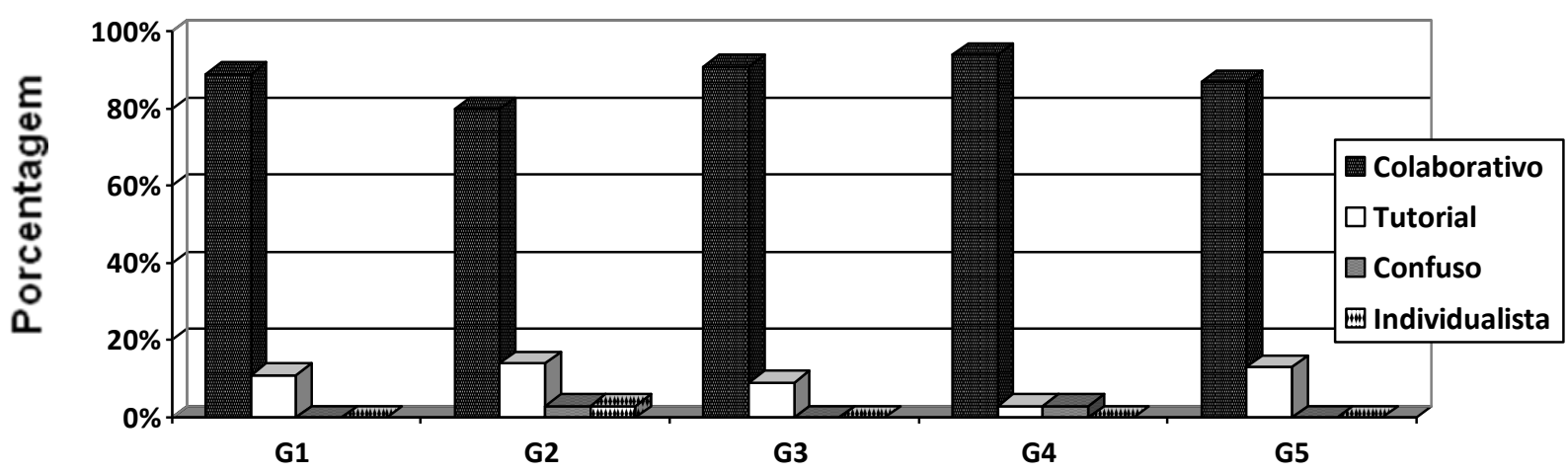

(a)

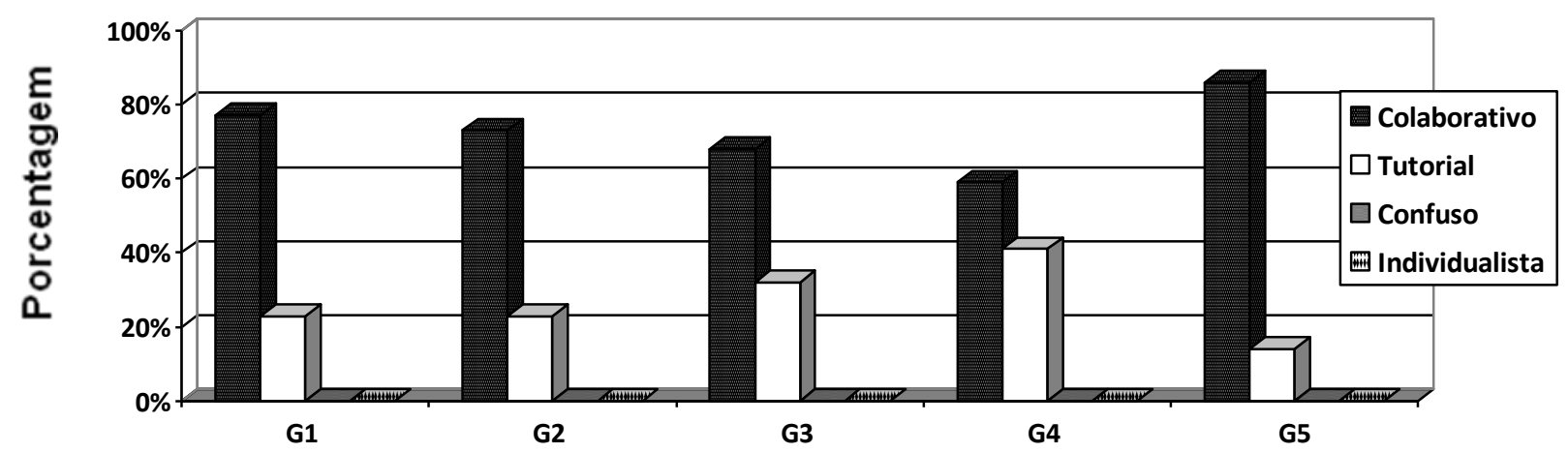

(b)

Figura 5.4 - Porcentagem de uso dos processamentos sociais durante a resolução da primeira (a) e segunda (b) atividade dos grupos de base.

Observamos que a primeira atividade de grupo de base apresentou predominantemente interação social do tipo colaborativa, com porcentagem superior a $80 \%$ em quase todos os grupos, sendo seguida pala interação do tipo tutorial, em média 10\%. O elevado grau de cooperação, evidenciado pelo predomínio do processamento social do tipo colaborativo ou tutorial, demonstra que a atividade conseguiu gerar nos alunos uma interdependência positiva, tornando-os parte de um conjunto, pensando no seu rendimento e também no rendimento dos seus companheiros.

Na primeira atividade observamos a ocorrência de interações do tipo confusa por duas vezes e individualista uma vez. A interação do tipo confusa ocorreu apenas 
uma vez em dois dos grupos (Grupo 2 e Grupo 4) no começo das suas atividades, em momentos em que os alunos não conseguiram definir uma estratégia para dar andamento aos seus trabalhos, entretanto, este tipo de interação seguido, por interações tutoriais levaram ambos os grupos a interagir de forma colaborativa. Com relação à interação do tipo individualista, a mesma foi pontual (Grupo 2) e não interferiu no bom andamento da atividade e, provavelmente, é devida ao hábito dos alunos de trabalharem sozinhos.

Com relação à segunda atividade, observamos que houve um avanço nas interações sociais desenvolvidas pelos alunos, uma vez que $100 \%$ das interações foram do tipo cooperativa, divididas entre processamento social colaborativo e tutorial, indicando uma evolução natural advinda provavelmente da estratégia jigsaw.

Nessa perspectiva, evidencia-se que a atividade, constituída em um período longo, trouxe benefícios para os alunos, que frente à repetição e reflexão sobre questões presentes na tarefa, tiveram a chance de evoluir em seu trabalho, individualmente e coletivamente, tornando-o mais cooperativo e eficiente.

\subsubsection{Processamento Social nos Grupos de Especialistas}

As interações sociais predominantes nos grupos de especialistas, assim como nos grupos de base, foram do tipo colaborativa. Conforme ilustrado na Figura 5.5, na qual são expostos os quatro tipos de interações sociais considerados neste trabalho, assim como os valores em porcentagem referentes à freqüência de uso dos diferentes processamentos sociais. 


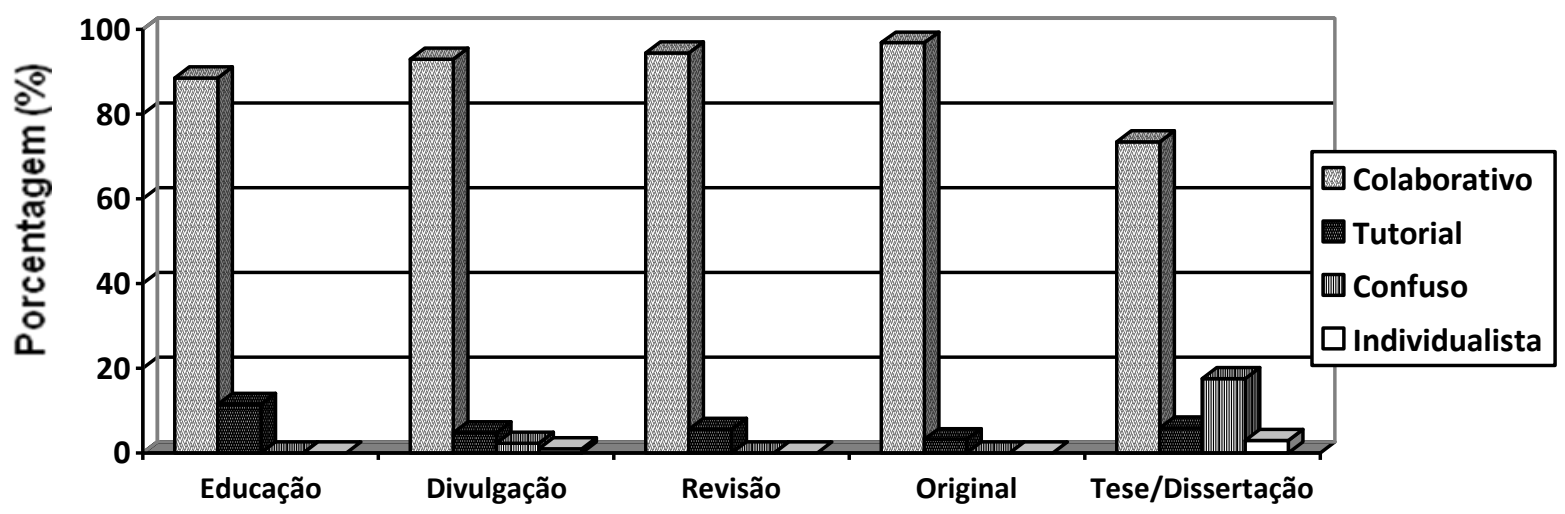

Figura 5.5 - Porcentagem de uso dos processamentos sociais durante a resolução da atividade dos grupos de especialistas.

Em todos os grupos as interações do tipo colaborativa foram superiores a $70 \%$ indicando o estabelecimento de uma interação na qual os alunos facilitam, com seus esforços, a aprendizagem dos demais. Estas interações sugerem de um modo geral uma atividade rica em possibilidades de crescimento social para os alunos. Entretanto, cabe destacar que no grupo de especialista em tese ou dissertação ocorreram interações que foram marcadas por atitudes não colaborativas, sendo $17 \%$ das interações do tipo confusa e $3 \%$ do tipo individualista. Estas interações refletem um comportamento individualista dos alunos e, por vezes, competitivo. Isto ocorreu devido ao fato de dois membros do grupo desviarem o foco da atividade o que passou a ser em alguns momentos motivo de conflito, gerando também um percentual mais elevado que o dos demais grupos, no que diz respeito ao processamento cognitivo off-task (em torno de $30 \%$ ), conforme ilustra a Figura 5.3. Apesar de tais episódios não terem atrapalhado os alunos na sua resolução nem na qualidade das respostas, estes devem ser sempre acompanhados pelo docente responsável. 


\subsection{Avaliação dos Alunos Frente à Atividade Proposta}

Conforme mencionamos anteriormente, com o término das tarefas solicitadas e das etapas de avaliação, os alunos responderam a um questionário sobre a atividade cooperativa empregada na disciplina. O questionário composto por quinze afirmações, foi respondido por 60 alunos. Este se pautou no trabalho de Eilks (2005), tendo em vista o conhecimento das impressões dos alunos sobre a aplicação do método cooperativo. Questões relacionadas à potencialidade do método estão presentes no questionário, composto de quinze afirmações, elencadas a seguir:

1. Eu pude trabalhar com mais independência no formato de aula jigsaw do que faço normalmente nas aulas expositivas;

2. Eu teria gostado mais se o professor tivesse nos ajudado mais diretamente e corrigido o nosso trabalho após cada uma das etapas do jigsaw;

3. Eu trabalhei com mais intensidade no formato de aula jigsaw do que costumo trabalhar durante as aulas expositivas/expositivas dialogadas;

4. Eu prefiro quando o professor discute tópicos com a classe toda (aula expositiva dialogada) do que quando nós temos que trabalhar em pequenos grupos;

5. Eu acredito que aprendi muito sobre o conteúdo "Algumas formas de divulgação científica" trabalhando no formato de aula jigsaw;

6. Eu não gostei de trabalhar no formato de aula jigsaw porque meu trabalho ficou muito dependente do desempenho dos meus colegas;

7. Eu acho que o formato de aula jigsaw é confuso e desestruturado;

8. Eu gostei de trabalhar no formato de aula jigsaw porque pude trabalhar junto com outros colegas,

9. Foi difícil organizar sozinhos o nosso trabalho no formato de aula jigsaw; 
10. O uso de diferentes métodos de ensino (como o formato de aula jigsaw) torna nossas aulas mais divertidas e menos cansativas;

11. Acredito que a distribuição de papéis entre os participantes dos grupos de base (mediador, porta-voz, facilitador, etc) facilitou a realização das atividades solicitadas pelo professor;

12. Acredito que a distribuição de papéis entre os participantes dos grupos de base(mediador, porta-voz, facilitador, etc) facilitou a organização do trabalho do grupo;

13. Ter um papel específico a desempenhar no grupo (mediador, porta-voz, facilitador, etc) me ajudou no desenvolvimento de novas habilidades ou no aperfeiçoamento de habilidades que eu já possuía

14. Considero que o processamento grupal, realizado no final dos trabalhos dos grupos de base, é importante para o bom andamento das atividades no grupo;

15. Eu gostaria de participar novamente de aulas no formato jigsaw na disciplina Comunicação e Expressão em Linguagem Científica.

A freqüência das respostas, expressa em escala Likert de cinco pontos (Concordo Fortemente (CF), Concordo (C), Indeciso (I), Discordo (D), Discordo Fortemente (DF)), foi quantificada e analisada.

Na Figura 5.6, é apresentada a quantificação da frequência das respostas, em porcentagem, como CF (Concordo Fortemente), C (Concordo), I (Indeciso), (Discordo) e DF (Discordo Fortemente), o eixo x corresponde à numeração das afirmações citadas anteriormente e o eixo y corresponde à freqüência de respostas dadas pelos alunos em escala Likert. 


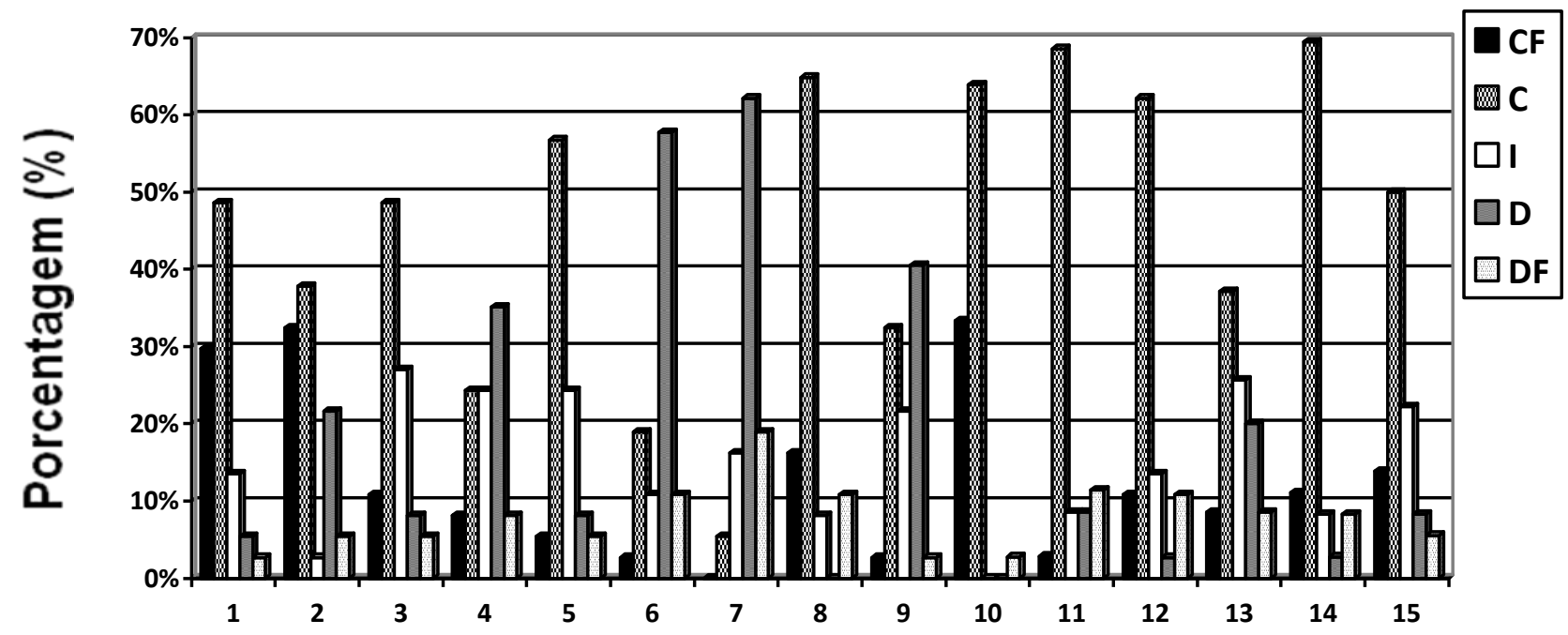

Afirmações

Figura 5.6 - Questionário de avaliação da atividade proposta, na qual $\mathrm{CF}=$ Concordo Fortemente, $\mathrm{C}=$ Concordo $\mathrm{I}=$ Indeciso, $\mathrm{D}=$ Discordo e DF= Discordo Fortemente.

Para que a discussão a respeito da avaliação dos graduandos sobre a proposta pudesse ser feita de forma mais clara, inicialmente agrupamos as afirmações contidas no questionário em 3 categorias. As respostas dadas para as afirmações 1, 3, 6, 8 e 15, se relacionam à opinião dos alunos com relação à sua conduta durante a realização da estratégia e à sua satisfação com relação à atividade realizada. Nas afirmações 1 e 3 os alunos opinaram sobre a independência e intensidade com que conduziram as tarefas pertencentes à atividade realizada.

Os resultados foram positivos com relação a tais afirmações, uma vez que grande parte dos alunos afirma ter trabalhado com maior independência $(78,4 \%$, somatório das respostas CF e C) e intensidade (59,4\%); somatório das respostas CF e C) durante a realização da atividade.

Com relação às impressões dos alunos sobre a dependência do trabalho dos demais colegas para o sucesso da tarefa realizada (afirmações 6 e 8), é possível verificar que os resultados foram bastante favoráveis à proposta, uma vez que a discordância dos alunos em relação à afirmação 6 foi elevada: 68,6\% de discordância 
(somatório das respostas D e DF). De forma complementar, a grande maioria dos alunos concordou haver gostado de trabalhar no formato de aula jigsaw porque era possível trabalhar junto com os outros colegas (afirmação 8): 81,1\% de concordância (somatório das respostas $\mathrm{C}$ e CF).

A satisfação dos alunos frente às atividades realizadas foi considerável, uma vez que a concordância em relação à afirmação 15, a qual se referia ao desejo de nova participação em aulas no formato jigsaw, superou a metade dos alunos: $63,9 \%$ de concordância (somatório das respostas C e CF).

Apresentamos na Figura 5.4 as respostas dadas para as afirmações 2, 4, 5, 7, 9 e 10, que dizem respeito à opinião dos alunos sobre a realização das atividades no formato jigsaw (questões 7 e 10) e às suas contribuições para o aprendizado dos conteúdos estudados (questão 5), assim como às suas percepções com relação à conduta do professor (2, 4 e 9).

As respostas dadas à afirmação 10 mostram que $97,2 \%$ dos alunos concordaram (somatório das respostas C e CF) que métodos como o jigsaw tornam as aulas menos cansativas e mais divertidas. As respostas dadas à afirmação 7, evidenciam que os alunos, em sua maioria, reconheceram a atividade como organizada, o que é relevante, já que um dos maiores obstáculos ao trabalho em grupo reside, justamente, na dificuldade da organização das tarefas (JOHNSON; JOHNSON; HOLUBEC, 1999; COCHITO, 2004). De fato, verificamos que $81,1 \%$ dos alunos discordaram (somatório das respostas D e DF) da afirmação que diz ser o formato de aula jigsaw confuso e desestruturado. Esse resultado positivo se deve, provavelmente, a dois fatores: a organização, imposta pela própria estrutura da atividade cooperativa, e à forma com que o docente conduziu a disciplina. 
No que diz respeito ao favorecimento da compreensão de conceitos (afirmação 5), a grande maioria dos alunos concordou com tal afirmação, conforme ilustra a Figuras 5.4. Assim, a natureza cooperativa do formato jigsaw não prejudicou o aprendizado dos conteúdos ministrados na disciplina.

Três afirmações se relacionavam à condução da aula pelo professor: a primeira, de caráter geral questão 4, solicitava aos alunos que indicassem se preferiam o formato de aula expositiva dialogada ao formato de trabalho em pequenos grupos; a segunda, de caráter específico (afirmação 2), solicitava aos alunos que indicassem se teriam gostado mais da atividade no formato adotado caso o professor os tivesse auxiliado mais diretamente no processo, corrigindo os trabalhos após cada uma das etapas do jigsaw,a terceira de caráter especifico também questionava a dificuldade em organizar sozinho o trabalho no formato de aula jigsaw; . No que diz respeito à afirmação 4, 32,4\% dos alunos explicitaram sua preferência por aulas expositivas dialogadas (somatório das respostas CF e C) e 43,3\% por aulas nas quais predominam atividades em grupo (somatório das respostas DF e D), enquanto $24,3 \%$ se declararam indecisos frente à afirmação.

Tal resultado não é surpreendente, pois pesquisas indicam que do ponto de vista de muitos alunos ensinar é algo que só os professores podem fazer, sendo mais confortável para eles um estilo de ensino baseado exclusivamente na exposição do professor (HAGEN, 2000). O fato da cooperação entre os pares ainda não estar presente de forma sistemática nos cursos universitários dificulta o desenvolvimento nos alunos do sentimento da importância dessa cooperação.

No que diz respeito à afirmação 2, a maioria dos alunos, 70,3\%, (somatório das respostas $\mathrm{CF}$ e $\mathrm{C}$ ), indicou que teria gostado mais do jigsaw se tivesse sido ajudado mais diretamente pelo docente, somado a isso as respostas a questão $9,35,0 \%$ 
(somatório das respostas CF e C) dos alunos afirmaram preferir que o professor ajudasse na organização da atividade.

Os alunos podem ter se surpreendido com o papel desempenhado pelo professor. Papel esse que na aprendizagem cooperativa ganha novas dimensões: quanto mais bem sucedido for o professor, maior será a transferência de 'poder' para os alunos, assim eles se tornarão mais autônomos, responsáveis e capazes de se auto-organizarem (COCHITO, 2004).

Apresentamos na Figura 5.4 as respostas dadas para as afirmações das questões, 11, 12, 13 e 14, que dizem respeito à opinião dos alunos sobre a realização das atividades no formato jigsaw com funções determinadas pelo docente. (questões 11,12 e 13) e às contribuições do processamento grupal para o desenvolvimento da atividade desenvolvida questão 14.

A aceitação das funções propostas pelo docente se mostrou quase total, o que pode ser visto nas (Q11) e (Q12) presentes na Figura 5.6, na qual mais de 70\% dos alunos afirmaram (somatório das respostas C e CF) que as funções definidas pelo docente facilitaram a resolução da atividade e contribuiu com a organização da atividade. Alem do caráter pratico das funções 45,7\% dos alunos ainda revelaram na (A13), acreditar que as funções ajudaram no desenvolvimento de habilidades. Aliado a isto, temos a constatação da afirmação (A14) na qual 80,6\% dos alunos confirmaram que o processamento grupal ajudou na organização da atividade.

Assim como no trabalho reportado por Eilks (2005), os alunos reagiram positivamente à aplicação da atividade no formato jigsaw. As respostas dadas ao questionário de avaliação mostraram sua satisfação com relação a esse formato de atividade, especialmente devido ao fato de terem trabalhado com mais independência (78,3\% de respostas favoráveis à afirmação 1) e junto com outros colegas $(81,1 \%$ de 
respostas favoráveis à afirmação 8). Ademais, foi praticamente unânime a concordância dos alunos com relação ao fato de aulas neste formato serem divertidas e pouco cansativas $(97,2 \%$ de respostas favoráveis à afirmação 10$)$.

É também digno de nota a importância creditada pelos alunos à atribuição de papéis entre os participantes do grupo de base $(71,4 \%$ de respostas favoráveis a questão $11 ; 73,0 \%$ favoráveis a questão 12$)$ e ao processamento grupal $(80,6 \%$ das respostas favoráveis a questão 14). Estes resultados corroboram as recomendações expressas por Johnson, Johnson e Holubec (1999) no sentido da promoção da interdependência positiva no grupo e da realização do processamento grupal.

Opiniões negativas frente às afirmações presentes no questionário foram raras. No entanto, como os estudantes não eram experientes no desenvolvimento de atividades no formato jigsaw, acreditamos que possivelmente tais opiniões seriam amenizadas caso eles tivessem outras oportunidades de familiarização com o método.

Os resultados apresentados indicam que a integração de atividades didáticas no formato jigsaw no nível superior pode melhorar a qualidade do ensino de Química, tanto no ponto de vista formativo quanto informativo. 


\section{CONSIDERAÇÕES FINAIS}

Desde a década de setenta, principalmente, vem ocorrendo a consolidação das pesquisas sobre as formas de organização e a efetividade das atividades didáticas pautadas nos princípios da aprendizagem cooperativa. No entanto, no contexto nacional são ainda escassas as investigações dedicadas à temática, especialmente no ensino de Química.

Neste trabalho colocamos em funcionamento uma atividade didática pautada nos preceitos da aprendizagem cooperativa (formato jigsaw) na disciplina "Comunicação e Expressão em Linguagem Científica I", oferecida aos alunos ingressantes no Curso de Bacharelado em Química do IQSC/USP.

O acompanhamento da aplicação da atividade nos permitiu investigar a dinâmica das interações estabelecidas entre os alunos, dentro dos seus respectivos grupos, a partir da análise das seguintes dimensões: funções da fala, processamento cognitivo e processamento social. Para tanto, nos baseamos no Modelo Analítico proposto por Kumpulainen e Mutanen (1999). De forma complementar, analisamos as percepções dos alunos com relação à aplicação da atividade, fazendo uso de questionário composto por quinze afirmações, baseado no trabalho de Eilks (2005). Assim, foi possível analisar a atividade do ponto de vista do seu atendimento aos 
fundamentos e expectativas da aprendizagem cooperativa, como definida pelos irmãos Johnson.

Com relação às funções de fala empregadas na primeira atividade nos grupos de base, os alunos usaram de forma predominante as funções do tipo interrogação (Int), resposta (Res), complemento de resposta (C-Res) e informação (Inf). Esta preferência indica um forte comprometimento por parte dos alunos em realizar a tarefa proposta pelo professor de forma eficiente. Aliado ao uso de tais funções, a ocorrência de processamento cognitivo rotineiro (PCR) foi elevada, o que corrobora o referido comprometimento. Já com relação às interações estabelecidas nos grupos de base, estas ocorreram de forma cooperativa, sendo conduzidas predominantemente por processamentos sociais do tipo colaborativo e tutorial, com poucos episódios definidos por processamentos sociais do tipo confusos e individualistas.

Com relação às funções de fala empregadas na segunda atividade dos grupos de base, a mesma tendência da primeira atividade foi observada, sendo as funções do tipo interrogação (Int), resposta (Res), complemento de resposta (C-Res) e informação (Inf) as mais usadas. Entretanto, é digno de nota o aumento do uso das funções resposta crítica (Res-C), citação critica (Cit-C) e organização de ideia (Org-I), indicando uma evolução com relação à atividade realizada no primeiro grupo de base. Reforça a constatação acima a observação do aumento também no uso do processamento cognitivo exploratório (PCE), evidenciando uma evolução no decorrer da atividade e sugerindo que os alunos realizaram um trabalho mais ativo e buscaram respostas mais elaboradas. É relevante perceber que os grupos, em sua maioria, apresentaram evolução, sinalizando a qualidade da atividade proposta.

Cabe ressaltar ainda que na segunda atividade os alunos possuíam conhecimentos com relação ao conteúdo ministrado na disciplina bastante pareados, 
tendo cada um que contribuir com parte essencial para o cumprimento da tarefa solicitada. Este aspecto tornou a participação de cada um deles mais importante e efetiva, justificando, pelo menos parcialmente, a evolução observada. Já com relação aos processamentos sociais realizados na segunda atividade, também observamos que houve um avanço nas interações sociais desenvolvidas pelos alunos, uma vez que $100 \%$ delas foram cooperativas, divididas entre processamento social colaborativo e tutorial.

Diante do exposto, podemos concluir que as atividades nos grupos de base proporcionaram aos alunos um ambiente cooperativo, no qual participaram de forma consideravelmente igualitária, desenvolvendo suas habilidades acadêmicas, atendendo, portanto, a grande parte das expectativas da aprendizagem cooperativa, como definida pelos irmãos Johnson.

Nos grupos de especialistas destacamos o uso das funções de fala do tipo organização de ação (Org-A), experiencial (Exp), julgamento (Jul), avaliação (Ava) e afetiva (Afe). Mesmo o uso de tais funções não sendo prioritário, se mostrou significativo, pois refletiu a intenção dos alunos em coordenar o trabalho do grupo e em contribuir com sugestões concordantes ou discordantes, de forma a avaliar o trabalho dos seus pares. Estes aspectos indicam uma forte interação nos grupos de especialistas, que passaram por vários episódios especulativos. Destacamos ainda que o uso das funções de fala organização de ideia (Org-I), citação critica (Cit-C) e resposta critica (Res-C) foi significativo, demonstrando que existiram alguns momentos de conflitos cognitivos durante esta atividade, levando os alunos à busca de respostas bem elaboradas. Este fato é confirmado pelo elevado uso do processamento cognitivo do tipo exploratório (PCE) que teve seu mínimo de 8,2\% no grupo especialista em artigo original e máximo de $19,1 \%$ no grupo especialista em artigo de revisão. Assim, o 
grupo de especialista responsável pelo uso mínimo de processamentos exploratórios usou, em valores percentuais, o dobro do valor dos grupos de base, que o fizeram em torno de 4\%. Nos grupos de especialistas foi também mantida uma postura cooperativa, verificando-se processamento social colaborativo com valores superiores a $70 \%$.

Diante do exposto, acreditamos que a atividade de especialista também proporcionou aos alunos um ambiente cooperativo, no qual tiveram a chance de enfrentar conflitos cognitivos, que geram um esforço para compreender e resolver problemas.

Assim, os resultados nos levam a crer que o fato da aplicação da atividade proposta no formato jigsaw ter sido substancialmente permeada pela presença dos cinco componentes essenciais descritos pelos irmãos Johnson (interdependência positiva, responsabilidade individual, interação face-a-face, habilidade interpessoais e processamento grupal) permitiu que os alunos trabalhassem de forma cooperativa. Com isso podemos inferir, como resposta aos nossos objetivos, primeiramente, que a aprendizagem cooperativa pode ser adaptada com sucesso ao ensino superior de Química; segundo, o seu uso acarreta benefícios acadêmicos e sociais para os alunos, que em busca de melhores respostas a questões colocadas pelo professor, interagem de forma intensa, trabalhando suas potencialidades e limitações.

Por fim, se coadunam com as constatações apresentadas acima, as impressões dos alunos frente à atividade. A grande maioria deles trabalhou de forma mais independente e apreciou a realização das tarefas em cooperação com outros colegas. Ademais, a atividade se mostrou divertida e pouco cansativa, confirmando o fator motivacional vinculado às estratégias cooperativas. 
Cabe esclarecer aos que pretendem lançar mão de estratégias cooperativas em ambientes de ensino que é importante estar consciente que a sua aplicação exige muito esforço, especialmente no que diz respeito à organização e administração das atividades, por parte do docente responsável. O que, por muitos, pode ser visto como uma limitação da estratégia, entretanto nossos resultados indicam que seu uso, se bem planejado, gera benefícios substanciais para os alunos. 


\section{REFERÊNCIAS BIBLIOGRÁFICAS}

ARONSON, E. The jigsaw classroom. Beverly Hills, CA: Sage, 1978.

ARMSTRONG, N.; CHANG, S.; BRICKMAN, M. Cooperative learning in industrial-sized biology classes. Cell Biology Education, v.6, n.2, p.163-171, Summer 2007.

BANERJEE, A. C.; VIDYAPATI, T. J. Effect of lecture and cooperative learning strategies on achievement in chemistry in undergraduate classes. International Journal of Science Education, v.19, n.8, p.903-910, 1997.

BARBOSA, R. M. N.; JÓFILI, Z. M. S. Aprendizagem cooperativa e ensino de química - parceria que dá certo. Ciência \& Educação, v. 10, n. 1, p. 55-61, 2004.

BARBOSA, R.; JÓFILI, Z.; WATTS, M. Cooperating in constructing knowledge: case studies from chemistry and citizenship. International Journal of Science Education, v. 26, n. 8, p.935-949, 2004.

CARVALHO, A. M. P. Ensino de ciências: unindo a pesquisa e a prática. São Paulo: Pioneira Thomson Learning, 2006. p.154.

COCHITO, M. I. S. Cooperação e aprendizagem: educação intercultural. Lisboa: ACIME, 2004. p.180.

DOUGHERTY, R. C. Grade/performance contracts, enhanced communication, cooperative learning and student performance in undergraduate organic chemistry. Journal of Chemical Education, v.74, n.6, p.722-726, 1997.

DOYMUS, K. Effects of a cooperative learning strategy on teaching and learning phases of matter and one-component phase diagrams. Journal of Chemical Education, v. 84, p.1857-1860, 2007.

EILKS, I., Experiences and reflections about teaching atomic structure in a jigsaw classroom in lower secondary school chemistry lessons. Journal of Chemical Education, v. 82, n. 2, p. 313-319, 2005.

FELDER, R. M. Active-inductive-cooperative learning: an instructional model for chemistry?. Journal of Chemical Education, 73, n.9, p.832-836, 1996.

FERNÁNDEZ-SANTANDER, A. Cooperative learning combined with short periods of lecturing. Biochemistry and Molecular Biology Education, v.36, n.1, p.34-38, 2008.

FERREIRA, J. F.; QUEIROZ, S. L. Percepções de graduandos em química sobre atividade cooperativa realizada no ambiente virtual cursos on-Line. Revista Brasileira de Informática na Educação, v.18, n. 2, p.43-52, 2010.

FOURLAS, G.; WRAY, D. Children's oral language: a comparison of two classroom organisational systems. In D. Wray, Emerging partnerships, Current research in language and literacy (p. 76-86). Clevedon: Multilingual Matters, 1990. 
GARCÍA, A. G.; TUÑÓN, M. J. I. El Ciclo reflexivo cooperativo: un modelo didáctico para la enseñanza de las ciencias. Revista Electrónica de Enseñanza de las Ciencias, v.3, n.2, p.148-160, 2004.

HAGEN, J. P., Cooperative learning in organic II. Increased retention on a commuter campus. Journal of Chemical Education, v. 77, n. 11, p. 1441-1444, 2000.

HELLER, P.; KEITH, R.; ANDERSON, S. Teaching problem solving through cooperative grouping. Part 1: Group Versus Individual Problem Solving. American Journal of Physics, v.60, n.7, p.627-636,1992.

JOHNSON, D. W., JOHNSON, R.T. Cooperation and competition: theory and research. Edina, MN: Interaction Book Company, 1989.

JOHNSON, D. W.; JOHNSON, R. T.; HOLUBEC, E. J. Los nuevos círculos del aprendizaje: la cooperación en el aula y la escuela. Virginia: Aique, 1999.

JOHNSON, D.W.; JOHNSON, R. T.; SMITH, K., The state of cooperative learning in postsecondary and professional settings. Educational Psychology Review, v. 19, n. 1, p.15-29, 2007.

KUMPULAINEN, K. MUTANEN, M. The situated dynamics of peer group interaction: an introduction to an analytic framework. Learning and Instruction, v. 9, p. 449-473, 1999.

KUMPULAINEN, K. The nature of children's oral language interactions during collaborative writing experience at the computer. 1994. Unpublished doctoral dissertation, University of Exeter, Exeter.

KUMPULAINEN, K. The nature of peer interaction in the social context created by the use of word processors. Learning and Instruction, v.6, p.243-261, 1996.

KUMPULAINEN, K.; MUTANEN, M. Collaborative practice of science construction in a computerbased multimedia environment. Computers \& Education, v.30, p.75-85, 1998.

LÜDKE, M.; ANDRÉ, M. E. D. A. Pesquisa em educação: abordagens qualitativas. São Paulo: Editora Pedagógica e Universitária Ltda, 1986.

LYON, D. C.; LAGOWSKI, J. J. Effectiveness of facilitating small-group learning in large lecture classes - A general chemistry case study. Journal of Chemical Education, v. 85, p.1571-1576, 2008.

MILLS, D.; MCKITTRICK, B. MULHALL, P.; FETERIS, S. CUP: Cooperative learning that works. Physics Education, v.34, n.1, p. 11-16, 1999.

OLIVEIRA, J. R. S.; QUEIROZ, S. L. Comunicação e linguagem científica: guia para estudantes de química. Campinas: Átomo, 2007. p.116.

SAMIULLAH, M. Effect of in-class student-student interaction on the learning of physics in a college physics course. American Journal of Physics, v.63, n.10, p.944-950, 1995. 
SEETHARAMAN, M.; MUSIER-FORSYTH, K. Does active learning through an antisense jigsaw make sense? Journal of Chemical Education, v.80, p.1404-1407, 2003.

SEIFERT, K.; FENSTER, A.; DILTS, J. A.; TEMPLE, L. An investigative, cooperative learning approach to the general microbiology laboratory. Cell Biology Education, v.8, n.2, p.147-153, 2009.

SLAVIN, R. E. Cooperative learning. New York: Longmann, 1983.

STAHL, R. J. Cooperative learning in science: a handbook for teachers. In: JOHNSON, D. W.; JOHNSON, R. T.; HOLUBEC, E. J. Learning together in the science classroom: practical applications. Menlo Park: Addison-Wesley, 1996. p.49-73.

TANNER, K.; CHATMAN, L. S.; ALLEN, D. Approaches to cell biology teaching: cooperative learning in the science classroom - beyond students working in groups. Cell Biology Education, v.2, p.1-5, Spring 2003.

THURSTON, A.; TOPPING, K. J.; TOLMIE, A.; CHRISTIE, D.; KARAGIANNIDOU, E.; MURRAY, P. Cooperative learning in science: follow-up from primary to high school. International Journal of Science Education, v.32, n.4, p.501-522, 2010.

TOWNS, M. H.; KREKE, K.; FIELDS, A. An action research project: student perspectives on small-group learning in chemistry. Journal of Chemical Education, v.77, n.1, p.111-115, 2000.

VALVERDE, G. J.; VIZA, A. M. L. Optimización metodológica de entornos telemáticos cooperativos (BSCW y SINERGEIA) como recursos didácticos de la química en la producción de hipermedia. Enseñanza de las ciencias, v.26, n.1, p.93-106, 2008.

VIDAL, D. G. Da caligrafia à escrita: experiências escolanovistas com caligrafia muscular nos anos 30. Revista da Faculdade de Educação, v.24, n.1, p.126-140, 1998.

ZUCCO, C.; PESSINE, F. B. T.; ANDRADE, J. B. Diretrizes curriculares para os cursos de química. Química Nova, v.22, n.3, p.454-461, 1999. 


\section{ANEXO A}

\section{Revistas analisadas (Área de Educação e Ensino de Ciências e Matemática)}

\section{Qualis A1}

Ciência e Educação (UNESP. Impresso)

Cultural Studies of Science Education (Print)

Enseñanza de las Ciencias

International Journal of Science Education

Physics Education (Bristol. Print)

Research in science \& technological education

Science \& Education (Dordrecht)

\section{Qualis A2}

Biochemistry and Molecular Biology Education

Cadernos CEDES (Impresso)

Cell Biology Education

Ensaio: Pesquisa em Educação em Ciências (Impresso)

Enseñanza de las Ciencias de la Tierra

Investigações em Ensino de Ciências (Online)

Investigações em Ensino de Ciências (UFRGS. Impresso)

Journal of Biological Education

Philosophy of Science (East Lansing)

Public Understanding of Science (Print)

REEC. Revista Electrónica de Enseñanza de las Ciencias

Revista Brasileira de Pesquisa em Educação em Ciências

Science in Context

Studies In History and Philosophy of Modern Physics

Revista Electrónica de Investigación en Educación en Ciencias (En línea)

\section{Qualis B1}

Revista Brasileira de Ensino de Física (Online)

SEED Journal. Semiotics, Evolution, Energy, and Development

Scientiae Studia (USP)

Science, Technology and Society

Revista Eureka sobre Enseñanza y Divulgación de las Ciencias

International Journal of Social Research Methodology (Print)

Revista Brasileira de História da Ciência

Revista de Enseñanza de la Física

American Journal of Physics 


\section{Qualis B2}

Alexandria (UFSC)

Educação e Pesquisa

Experiências em Ensino de Ciências (UFRGS)

Latin American Journal of Physics Education

Revista Brasileira de Educação (Impresso)

Revista Brasileira de Informação na Educação

Revista Chilena de Educación Científica

Revista de la Facultad de Ciencia y Tecnologia 


\section{ANEXO B}

\section{Questionário de caracterização}

Nome completo:

Idade:

\section{BLOCO 1}

1) Quais foram os motivos que levaram você a prestar vestibular para o curso de Bacharelado em Química?

2) Já tinha contato com algum profissional da área de Química? Se sim, com quem?

3) O que você acredita que um profissional da Química deve "saber" e "saber fazer" para ser bem sucedido na sua profissão?

4) Acredita que alcançará este aprendizado (este "saber" e "saber fazer") na universidade? De que forma?

5) Onde você realizou o ensino fundamental?

( ) Rede Pública ( ) Rede Privada ( ) Parte na Rede Pública e parte na Rede Privada

6) Onde você realizou o ensino médio?

( ) Rede Pública ( ) Rede Privada ( ) Parte na Rede Pública e parte na Rede Privada

7) Você teve alguma outra experiência durante ou após esse período (outro curso de graduação, curso técnico-profissionalizante, etc.). Se sim, especifique.

\section{BLOCO 2}

1) Quantos livros você lê, em média, por ano?

( )menos de 1; ( )1 a 3; ( )3 a 6; ( )mais de 6

2) No seu cotidiano, você lê mais freqüentemente:

( )livros; ( )jornais; ( )revistas; ( )outros. Quais?

3) Você tem interesse por trabalhos relacionados à Ciência (divulgação de novas descobertas, aspectos históricos, formas de produção, etc.)? Se sim, quais tipos de trabalhos dessa natureza você já leu? Lembra de algum que tenha chamado a sua atenção?

4)A produção e a divulgação do conhecimento científico envolvem diversas formas de comunicação. Algumas delas estão citadas abaixo. Assinale aquelas que você conhece:

( )Artigos de divulgação científica; ( )Livros didáticos de Ciências; ( )Relatórios de pesquisa; ( )Artigos científicos; ( )Trabalhos apresentados em reuniões científicas; ( )Projetos de pesquisa; ( loutros. Quais? Você já participou de algum evento científico? Se sim, Qual(is)?

5) Verifique a lista de revistas de divulgação científica citadas a seguir e assinale aquelas que você já teve a oportunidade de ler.

( ) Scientific American Brasil ( )Superinteressante

( )Pesquisa Fapesp ( )Ciência Hoje ( ) Galileu

BLOCO 3

1) Que gênero de leitura você prefere?

2) Na maioria das vezes, com que finalidade você lê?

3) Acha importante a leitura? Por quê? Você tem tempo para ler durante o seu dia?

4) Você assina ou lê, freqüentemente, alguma revista ou jornal? Se sim, qual(is)? Essa leitura representa alguma contribuição para você? Se sim, qual(is)?

5) Você lia revistas infantis? Relate brevemente as leituras mais marcantes que realizou na sua infância. 
6) Já ganhou livro de presente? Qual(is)? Se não ganhou, o que sentiria se ganhasse?

7) Já deu livro a alguém? Qual(is)?

8) Quais os últimos livros que você leu?

9) Tem algum livro que você gostaria de ler, mas não leu? Por quê?

10) Há alguma coisa que você tenha lido e nunca mais tenha esquecido? Por que não esqueceu? Qual o título e o autor?

11) Você relê um texto/livro quando gosta dele?

12) Você pára na banca de jornal para ler as manchetes do dia?

13) Gosta de escrever? Escreve o que e onde?

14)Quando vai estudar como é a sua relação com a leitura? Quando lê com outro propósito o faz da mesma maneira?

\section{BLOCO 4}

1)Durante a sua vida estudantil você realizou trabalhos em grupo? ( )Sim ( )Não

2) Se sim, com qual freqüência (quantas vezes em média, por ano)?

3) Em quais ocasiões (quais atividades, quais disciplinas) foi solicitada a sua participação, na escola, em trabalhos em grupo?

4) O trabalho em grupo, na escola, agrada a você? ( )Sim ( )Não. Justifique sua resposta. 


\section{ANEXO C \\ Termo de Consentimento e Informação}

Nome da Pesquisa: Aprendizagem Cooperativa no Ensino de Química.

Pesquisadora responsável: Profa. Dra. Salete Linhares Queiroz

Informações sobre a pesquisa: Por meio de leituras, discussões realizadas em sala de aula e do material escrito produzido pelos alunos (durante as aulas de Comunicação e Expressão em Linguagem Científica I e II, ministradas no ano de 2008) deseja-se identificar características inerentes à aprendizagem cooperativa e discutir as suas potencialidades no Ensino de Química.

Assim, convidamos você, aluno de graduação em química no primeiro ano, a participar deste estudo. Assumimos o compromisso de manter sigilo quanto a sua identidade, como também garantimos que o desenvolvimento da pesquisa foi planejado de forma a não produzir riscos ou desconforto para os participantes. Pedimos também autorização para gravar (gravação em áudio e vídeo) o que for falado durante as aulas.

Profa. Dra. Salete Linhares Queiroz 
$\mathrm{Eu}$,

$\mathrm{RG}$ abaixo assinado, tendo recebido as informações acima, e ciente dos meus direitos, concordo em participar da referida pesquisa, bem como ter:

1. A garantia de receber todos esclarecimentos sobre todas as discussões antes e durante o desenvolvimento da pesquisa podendo afastar-me a qualquer momento assim que desejar.

2. A segurança plena de que não serei identificado, mantendo o caráter oficial da informação, assim como está assegurado que a pesquisa não acarretará nenhum prejuízo individual ou coletivo.

3. A segurança de que não terei nenhum tipo de despesa material ou financeira durante o desenvolvimento da pesquisa, bem como esta pesquisa não causará nenhum tipo de risco, dano físico, ou mesmo constrangimento moral e ético.

4. A garantia de que toda e qualquer responsabilidade nas diferentes fases da pesquisa é dos pesquisadores, bem como fica assegurado que haverá ampla divulgação dos resultados finais nos meios de comunicação e nos órgão de divulgação científica em que a mesma seja aceita.

5. A garantia de que todo material resultante será usado exclusivamente para a construção da pesquisa e ficará sob guarda dos pesquisadores.

Tendo ciência do exposto acima, desejo participar da pesquisa.

São Calos, de de 2008.

Assinatura do participante 


\section{ANEXO D \\ Tarefa previa para atividade dos grupos de Base}

\begin{tabular}{|c|c|}
\hline $\begin{array}{l}\text { GRUPOS } \\
\text { (BASE B) }\end{array}$ & TAREFA \\
\hline $1 \mathrm{~B}$ & $\begin{array}{l}\text { - Química Nova (qualquer artigo da seção Educação) } \\
\text { - Química Nova (qualquer artigo da seção Revisão) } \\
\text { - Eclética Química (qualquer artigo da revista publicado entre } 2004 \text { e 2008) } \\
\text { - Scientific American Brasil (qualquer artigo da seção Como Funciona) } \\
\text { - Tese de doutorado (qualquer tese defendida no IQSC entre } 2004 \text { e 2008) }\end{array}$ \\
\hline $2 \mathrm{~B}$ & $\begin{array}{l}\text { - Química Nova na Escola (qualquer artigo da seção Experimentação no Ensino de } \\
\text { Química) } \\
\text { - Química Nova (qualquer artigo da seção Revisão) } \\
\text { - Polímeros: Ciência e Tecnologia (qualquer artigo classificado como Artigo } \\
\text { Técnico Científico) } \\
\text { - Revista Pesquisa FAPESP (qualquer artigo da revista relacionado à área de } \\
\text { Química) } \\
\text { - Dissertação de mestrado (qualquer dissertação defendida no IQSC entre } 2004 \text { e } \\
\text { 2008) }\end{array}$ \\
\hline $3 B$ & $\begin{array}{l}\text { - Química Nova na Escola (qualquer artigo da seção O Aluno em Foco) } \\
\text { - Química Nova (qualquer artigo da seção Revisão) } \\
\text { - Revista Fitos: Pesquisa, Desenvolvimento e Inovação em Fitoterápicos (qualquer } \\
\text { artigo da seção Artigo Original, que seja relacionado à área de Química) } \\
\text { - Revista Ciência Hoje (qualquer artigo da seção Mundo da Ciência) } \\
\text { - Tese de doutorado (qualquer tese defendida no IQSC) }\end{array}$ \\
\hline 4B & $\begin{array}{l}\text { - Química Nova na Escola (qualquer artigo da seção Experimentação no Ensino de } \\
\text { Química) } \\
\text { - Química Nova (qualquer artigo da seção Revisão) } \\
\text { - Química Nova (qualquer artigo da seção Artigo) } \\
\text { - Revista Galileu (qualquer artigo da seção Lab) } \\
\text { - Trabalho de Conclusão de Curso/Monografia (qualquer monografia apresentada } \\
\text { no IQSC) }\end{array}$ \\
\hline $5 \mathrm{~B}$ & $\begin{array}{l}\text { - Química Nova (qualquer artigo da seção Educação) } \\
\text { - Química Nova (qualquer artigo da seção Revisão) } \\
\text { - Polímeros: Ciência e Tecnologia (qualquer artigo classificado como Artigo } \\
\text { Técnico Científico) } \\
\text { - Revista Superinteressante (qualquer artigo da revista) } \\
\text { - Dissertação de mestrado (qualquer dissertação defendida no IQSC entre } 2004 \text { e } \\
\text { 2008) }\end{array}$ \\
\hline
\end{tabular}




\section{ANEXO E \\ $\underline{\text { Tarefa I - Grupos de Base }}$}

1) Escrevam o título, a origem (nome da revista) e o nome dos autores de cada um dos textos que o grupo tem em mãos e classifiquem os mesmos como pertencentes a uma das categorias indicadas abaixo. Justifique a resposta.

2) Indiquem com quais tipos de texto os membros do grupo possuem familiaridade e com quais não possuem.

3) Indiquem qual foi o procedimento adotado pelo grupo para localização dos textos (caso a caso) e o grau de dificuldade enfrentado para a realização do referido trabalho.

4) Discutam e indiquem em quais aspectos os textos diferem e em quais aspectos se assemelham (se for o caso).

5) Organizem as conclusões da discussão no formato de um texto ou de uma tabela.

\section{Categorias de textos:}

- Tese/Monografia/Dissertação;

- Artigo que relata resultado original de pesquisa;

- Artigo de revisão;

- Artigo direcionado para a área de Educação em Ciências/Química;

- Artigo de divulgação científica. 


\section{ANEXO F}

\section{Artigos de Educação em Ciências}

1) IDENTIFICAÇÃO

a. Cite o título e a revista na qual foi publicado o trabalho que você tem em mãos.

b. Quais são as características profissionais que você imagina que os autores do trabalho possuem? É possível fazer algum tipo de afirmação neste sentido, com base no que está escrito no trabalho? Por quê?

c. É possível identificar a qual Instituição os autores estão vinculados? Você considera que a Instituição de origem dos autores pode influenciar na aceitação (ou não) do artigo para publicação? Por quê?

d. Qual é a periodicidade e a tiragem da revista na qual o artigo foi publicado?

e. Em qual local a revista trazida para a discussão costuma ficar disponível?

2) Sobre a ESTRUTURA DO TEXTO, responda:

a. Como o texto do artigo está organizado?

b. Quais são as divisões internas do texto (títulos e subtítulos)?

c. Além do texto escrito, existem outros recursos visuais (figuras, gráficos e tabelas, por exemplo) que foram utilizados pelos autores? Se sim, quais são eles e quantas vezes aparecem no corpo do texto?

d. Existem formas características de apresentação dos recursos (citados no item b) no texto? Qual (is)?

3) Sobre as CITAÇÕES e as REFERÊNCIAS BIBLIOGRÁFICAS, responda:

Obs.: Para responder as questões abaixo consulte o livro Comunicação e Linguagem

Científica: guia para estudantes de Química (Oliveira e Queiroz, 2007), páginas 71 a 79.

a. Existem citações de outros trabalhos inseridas no texto? Se sim, como as citações são feitas?

b. Existe uma lista com referências bibliográficas no final do texto (seção de referências bibliográficas)? Se sim, quantas referências ele apresenta?

4) Sobre o CONTEÚDO do texto, responda:

a. Qual é o público-alvo do artigo e da revista analisada por você? Justifique sua resposta.

b. Que tipo de informações/conteúdos o artigo analisado costuma trazer? 


\section{Artigos Originais}

\section{1) IDENTIFICAÇÃO}

a. Cite o título e a revista na qual foi publicado o trabalho que você tem em mãos.

b. Quais são as características profissionais que você imagina que os autores do trabalho possuem? É possível fazer algum tipo de afirmação neste sentido, com base no que está escrito no trabalho? Por quê?

c. É possível identificar a qual Instituição os autores estão vinculados? Você considera que a Instituição de origem dos autores pode influenciar na aceitação (ou não) do artigo para publicação? Por quê?

d. Qual é a periodicidade e a tiragem da revista na qual o artigo foi publicado?

e. Em qual local a revista trazida para a discussão costuma ficar disponível?

2) Sobre a ESTRUTURA DO TEXTO, responda:

a. Como o texto do artigo está organizado?

b. Quais são as divisões internas do texto (títulos e subtítulos)?

c. Além do texto escrito, existem outros recursos visuais (figuras, gráficos e tabelas, por exemplo) que foram utilizados pelos autores? Se sim, quais são eles e quantas vezes aparecem no corpo do texto?

d. Existem formas características de apresentação dos recursos (citados no item b) no texto? Qual (is)?

3) Sobre as CITAÇÕES e as REFERÊNCIAS BIBLIOGRÁFICAS, responda:

Obs.: Para responder as questões abaixo consulte o livro Comunicação e Linguagem Científica: guia para estudantes de Química (Oliveira e Queiroz, 2007), páginas 71 a 79.

a. Existem citações de outros trabalhos inseridas no texto? Se sim, como as citações são feitas?

b. Existe uma lista com referências bibliográficas no final do texto (seção de referências bibliográficas)? Se sim, quantas referências ele apresenta?

4) Sobre o CONTEÚDO do texto, responda:

a. Qual é o público-alvo do artigo e da revista analisada por você? Justifique sua resposta.

b. Que tipo de informações/conteúdos o artigo analisado costuma trazer? 


\section{Artigos de Divulgação Científica}

\section{1) IDENTIFICAÇÃO}

a. Cite o título e a revista na qual foi publicado o trabalho que você tem em mãos.

b. Quais são as características profissionais que você imagina que os autores do trabalho possuem? É possível fazer algum tipo de afirmação neste sentido, com base no que está escrito no trabalho? Por quê?

c. É possível identificar a qual Instituição os autores estão vinculados? (Se for o caso).

d. Qual é a periodicidade e a tiragem da revista na qual o artigo foi publicado?

e. Em qual local a revista trazida para a discussão costuma ficar disponível?

2) Sobre a ESTRUTURA DO TEXTO, responda:

a. Como o texto do artigo está organizado?

b. Quais são as divisões internas do texto (títulos e subtítulos)?

c. Além do texto escrito, existem outros recursos visuais (figuras, gráficos e tabelas, por exemplo) que foram utilizados pelos autores? Se sim, quais são eles e quantas vezes aparecem no corpo do texto?

d. Existem formas características de apresentação dos recursos (citados no item b) no texto? Qual (is)?

3) Sobre as CITAÇÕES e as REFERÊNCIAS BIBLIOGRÁFICAS, responda:

Obs.: Para responder as questões abaixo consulte o livro Comunicação e Linguagem

Científica: guia para estudantes de Química (Oliveira e Queiroz, 2007), páginas 71 a 79.

a. Existem citações de outros trabalhos inseridas no texto? Se sim, como as citações são feitas?

b. Existe uma lista com referências bibliográficas no final do texto (seção de referências bibliográficas)? Se sim, quantas referências ele apresenta?

4) Sobre o CONTEÚDO do texto, responda:

a. Qual é o público-alvo do artigo e da revista analisada por você? Justifique sua resposta.

b. Que tipo de informações/conteúdos o artigo analisado costuma trazer? 


\section{Artigos de Revisão}

\section{1) IDENTIFICAÇÃO}

a. Cite o título e a revista na qual foi publicado o trabalho que você tem em mãos.

b. Quais são as características profissionais que você imagina que os autores do trabalho possuem? É possível fazer algum tipo de afirmação neste sentido, com base no que está escrito no trabalho? Por quê?

c. É possível identificar a qual Instituição os autores estão vinculados? Você considera que a Instituição de origem dos autores pode influenciar na aceitação (ou não) do artigo para publicação? Por quê?

d. Qual é a periodicidade e a tiragem da revista na qual o artigo foi publicado?

e. Em qual local a revista trazida para a discussão costuma ficar disponível?

2) Sobre a ESTRUTURA DO TEXTO, responda:

a. Como o texto do artigo está organizado?

b. Quais são as divisões internas do texto (títulos e subtítulos)?

c. Além do texto escrito, existem outros recursos visuais (figuras, gráficos e tabelas, por exemplo) que foram utilizados pelos autores? Se sim, quais são eles e quantas vezes aparecem no corpo do texto?

d. Existem formas características de apresentação dos recursos (citados no item b) no texto? Qual (is)?

3) Sobre as CITAÇÕES e as REFERÊNCIAS BIBLIOGRÁFICAS, responda:

Obs.: Para responder as questões abaixo consulte o livro Comunicação e Linguagem

Científica: guia para estudantes de Química (Oliveira e Queiroz, 2007), páginas 71 a 79.

a. Existem citações de outros trabalhos inseridas no texto? Se sim, como as citações são feitas?

b. Existe uma lista com referências bibliográficas no final do texto (seção de referências bibliográficas)? Se sim, quantas referências ele apresenta?

4) Sobre o CONTEÚDO do texto, responda:

a. Qual é o público-alvo do artigo e da revista analisada por você? Justifique sua resposta.

b. Que tipo de informações/conteúdos o artigo analisado costuma trazer? 


\section{Teses e Dissertações}

\section{1) IDENTIFICAÇÃO}

a. Cite o título do trabalho que você tem em mãos e apresente a sua categoria (monografia, dissertação, tese).

b. Quais são as características profissionais que você imagina que os autores do trabalho possuem? É possível fazer algum tipo de afirmação neste sentido, com base no que está escrito no trabalho? Por quê?

c. É possível identificar a qual Instituição os autores estão vinculados? Você considera que a Instituição de origem dos autores pode influenciar na aceitação (ou não) do artigo para publicação? Por quê?

d. Qual é o intervalo de tempo que você imagina ser necessário para a produção de um documento desse tipo?

e. Em qual local o documento trazido costuma ficar disponível?

2) Sobre a ESTRUTURA DO TEXTO, responda:

a. Como o texto do documento está organizado?

b. Quais são as divisões internas do texto (títulos)?

c. Além do texto escrito, existem outros recursos visuais (figuras, gráficos e tabelas, por exemplo) que foram utilizados pelos autores? Se sim, quais são eles e quantas vezes aparecem no corpo do texto?

d. Existem formas características de apresentação dos recursos (citados no item b) no texto? Qual (is)?

3) Sobre as CITAÇÕES e as REFERÊNCIAS BIBLIOGRÁFICAS, responda:

Obs.: Para responder as questões abaixo consulte o livro Comunicação e Linguagem Científica: guia para estudantes de Química (Oliveira e Queiroz, 2007), páginas 71 a 79.

a. Existem citações de outros trabalhos inseridas no texto? Se sim, como as citações são feitas?

b. Existe uma lista com referências bibliográficas no final do texto (seção de referências bibliográficas)? Se sim, quantas referências ele apresenta?

4) Sobre o CONTEÚDO do texto, responda:

a. Qual é o público-alvo do documento analisado por você? Justifique sua resposta.

b. Que tipo de informações/conteúdos o documento analisado costuma trazer? 


\section{ANEXO G}

\section{Tarefa: Grupo de Especialistas}

ASSINATURA DOS MEMBROS:

1) Todos os membros do grupo de especialistas estudaram o mesmo tipo de documento científico e resolveram uma tarefa de casa na semana passada. $\mathrm{Na}$ aula de hoje as seguintes etapas devem ser cumpridas:

ETAPA 1: Os membros do grupo devem tomar conhecimento das respostas dadas pelos seus componentes para cada uma das questões da tarefa de casa. Devem discutir as respostas dadas e chegar a um consenso sobre a resposta mais ADEQUADA (e a mais COMPLETA possível) para cada uma delas;

ETAPA 2: A partir das respostas consensuais encontradas pelo grupo, um texto deve ser produzido, englobando todos os conhecimentos adquiridos. Este texto será utilizado, na próxima semana, por cada um dos especialistas para ensinar aos seus colegas dos grupos de base tudo o que aprenderam sobre o documento científico em questão. Assim, todos os membros do grupo precisam dispor do texto produzido;

ETAPA 3: Organizem as conclusões da discussão anterior, que gerou o texto solicitado acima, no formato de um Mapa Conceitual (usar caneta).

OBS: Não é necessária a realização do PROCESSAMENTO GRUPAL nesta aula.

O que são mapas conceituais?

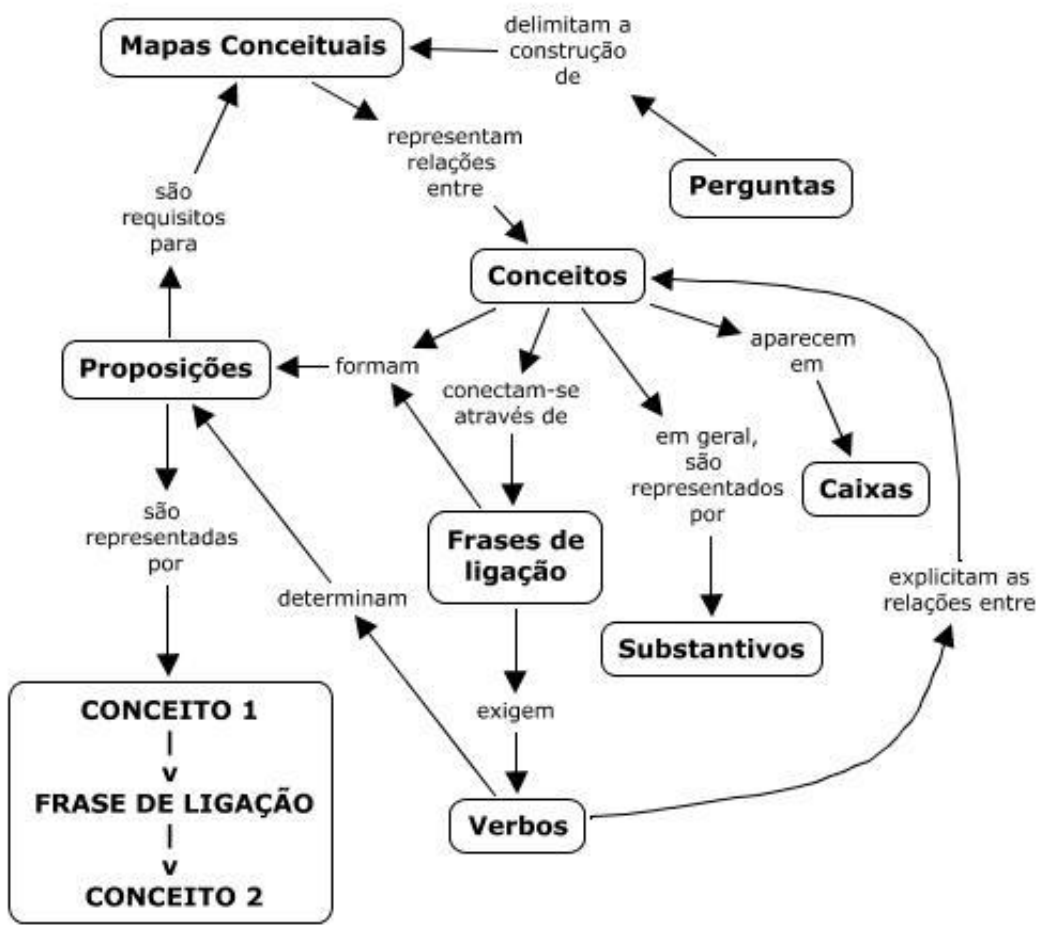

Figura 1 - Definição e esquema para construção de um mapa conceitual.

Mapas conceituais são diagramas indicando relações entre conceitos, ou entre palavras que usamos para representar conceitos (Figura 1). 


\begin{abstract}
ANEXO H
Afirmações presentes no questionário de avaliação da atividade com o jigsaw. Para cada uma das delas os alunos escolheram entre as seguintes opções: Concordo Fortemente, Concordo, Indeciso, Discordo e Discordo Fortemente.
\end{abstract}

1. Eu pude trabalhar com mais independência no formato de aula jigsaw do que faço normalmente nas aulas expositivas.

2. Eu teria gostado mais se o professor tivesse nos ajudado mais diretamente e corrigido o nosso trabalho após cada uma das etapas do jigsaw.

3. Eu trabalhei com mais intensidade no formato de aula jigsaw do que costumo trabalhar durante as aulas expositivas/expositivas dialogadas.

4. Eu prefiro quando o professor discute tópicos com a classe toda (aula expositiva dialogada) do que quando nós temos que trabalhar em pequenos grupos.

5. Eu acredito que aprendi muito sobre o conteúdo "Algumas formas de divulgação científica" trabalhando no formato de aula jigsaw.

6.Eu não gostei de trabalhar no formato de aula jigsaw porque meu trabalho ficou muito dependente do desempenho dos meus colegas.

7. Eu acho que o formato de aula jigsaw é confuso e desestruturado.

8. Eu gostei de trabalhar no formato de aula jigsaw porque pude trabalhar junto com outros colegas.

9. Foi difícil organizar sozinhos o nosso trabalho no formato de aula jigsaw.

10. O uso de diferentes métodos de ensino (como o formato de aula jigsaw) torna nossas aulas mais divertidas e menos cansativas.

11. Acredito que a distribuição de papéis entre os participantes dos grupos de base (mediador, porta-voz, facilitador, etc) facilitou a realização das atividades solicitadas pelo professor.

12. Acredito que a distribuição de papéis entre os participantes dos grupos de base(mediador, porta-voz, facilitador, etc) facilitou a organização do trabalho do grupo.

13. Ter um papel específico a desempenhar no grupo (mediador, porta-voz, facilitador, etc) me ajudou no desenvolvimento de novas habilidades ou no aperfeiçoamento de habilidades que eu já possuía.

14. Considero que o processamento grupal, realizado no final dos trabalhos dos grupos de base, é importante para o bom andamento das atividades no grupo.

15. Eu gostaria de participar novamente de aulas no formato jigsaw na disciplina Comunicação e Expressão em Linguagem Científica. 